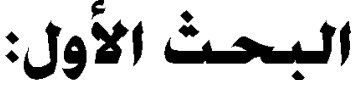

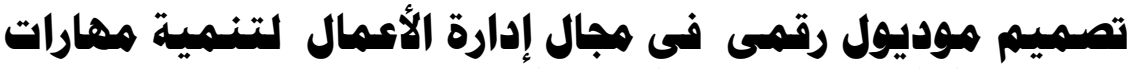
التفطيط الاستراتيجى و الإبداع الإدارى لطيمى إلاب التعليم الفنى

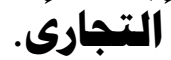

\section{: إلحإ}

أ.د / فاتن عبد المجيد السعودى فوده

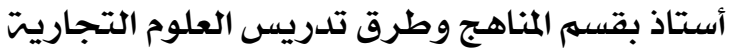

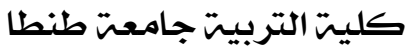

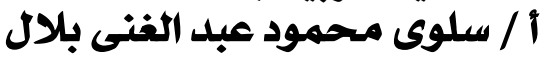

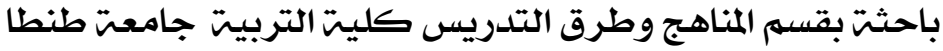

ومعلم اول اخصائى تكنولوجيا تعليم بالغربيت 



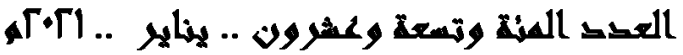

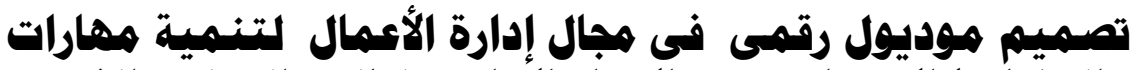

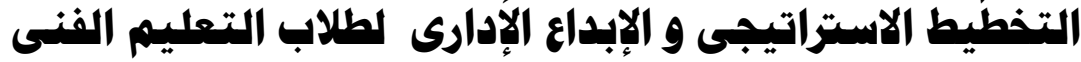 التبمارى.
}

\author{
أ.د / فاتن عبد المجيد السعودى فوده

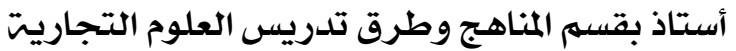

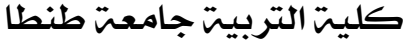

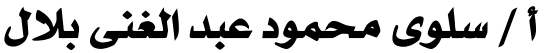

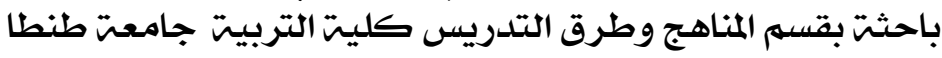

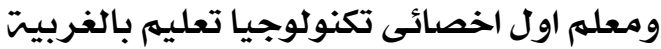

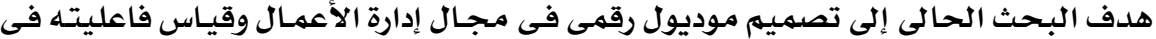

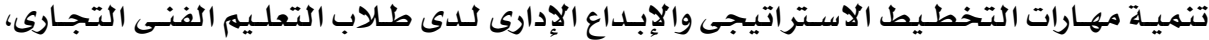

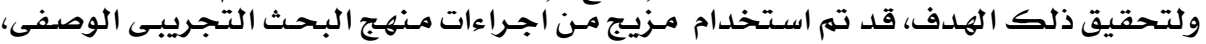

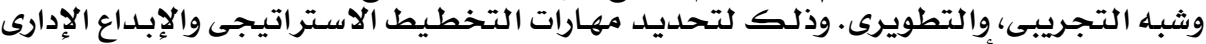

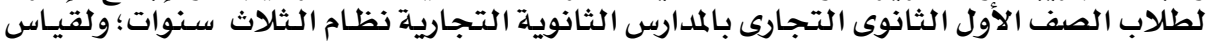

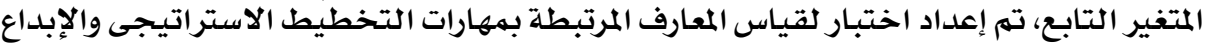

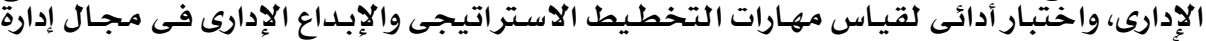

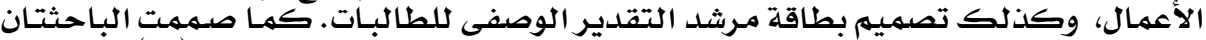

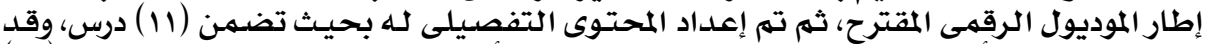

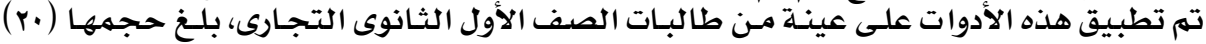

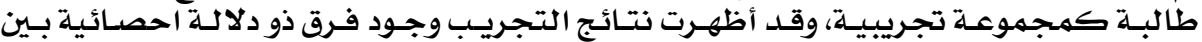

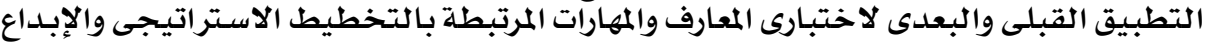

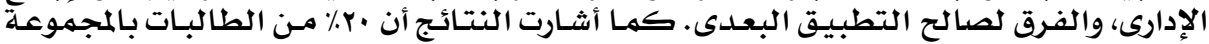

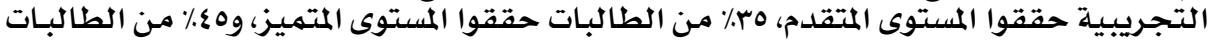

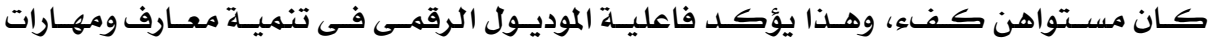

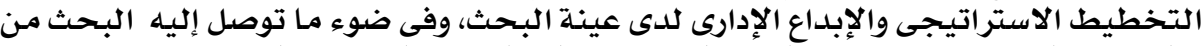

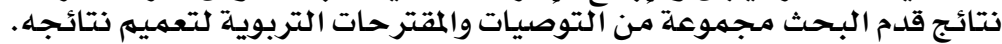

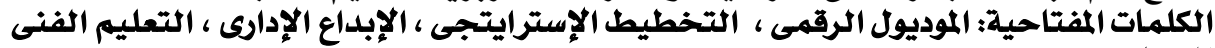

Design a Digital Module in Business Administration to Develop التحارى.

Strategic Planning and Administrative Creativity Skills of the Commercial Technical Education Learners

Dr. Faten Abdel magied El soudy Fouda

Ms. Salwa Mahmoud Abdulghany

$\underline{\text { Abstract }}$

This research amid at designing a digital module in the field of business administration and measure its effectiveness on developing strategic planning and administrative creativity skills of the commercial technical school learners. To achieve this goal, a mixed method approach of quasiexperimental and developmental research was adopted. The researcher has identified the strategic planning and administrative creativity skills needed for the first year learners in the commercial secondary schools, Three-year system. To measure the impact of the independent variable on the dependent 


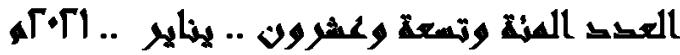

variable, a knowledge test of the strategic planning and administrative creativity was developed along with a performance test supported by an observational scaling rubric checklist. To measure the effectiveness of the suggested digital module, the researcher developed a detailed eContent that contains 11 micro lessons. All of the above was applied on a sample of female learners consisted of 20 learners from the first year of commercial secondary schools as an experimental group. The findings revealed that there is a significant difference between the pre and post application of the knowledge and performance test of strategic planning and administrative creativity. This statistical difference was in favor of the post measurement. The results also showed that 20\% of experimental group achieved advanced level of performance, 35\% achieved the distinguished level, and the rest of them (45\%) achieved the competent level. These results confirm the effectiveness of the suggested digital module in developing the knowledge and skills of strategic planning and administrative creativity among the research sample. Based on these findings, a set of recommendations and suggestions were highlighted to generalize this research results.

Keywords: eLearning, Digital module, Strategic planning, Administrative creativity, Commercial Technical Education.

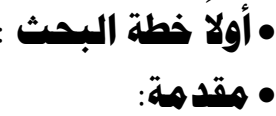

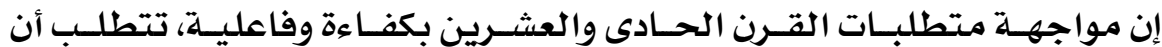

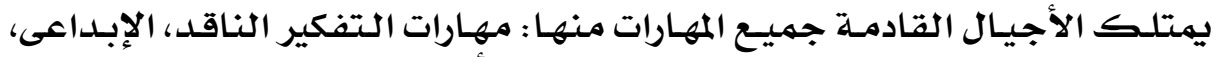

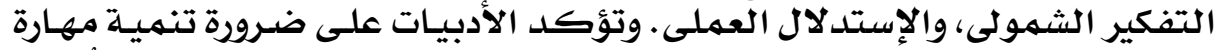

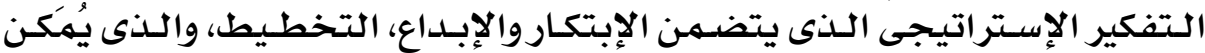

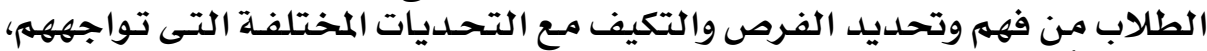

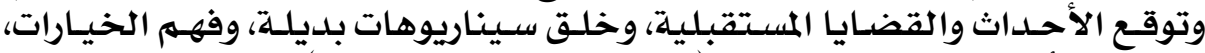
واختيار الأهداف وتحديد الإتجاه (Herrmann-Nehdi,2014).

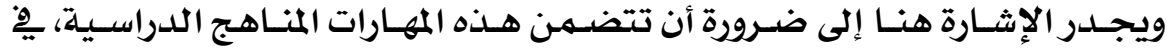

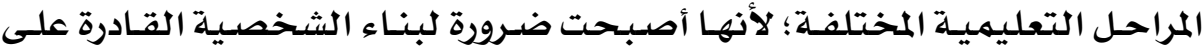

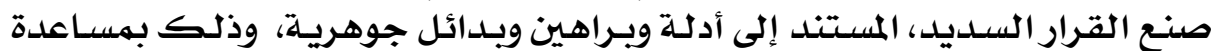

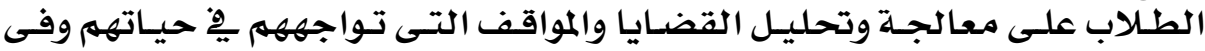

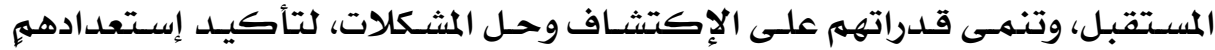

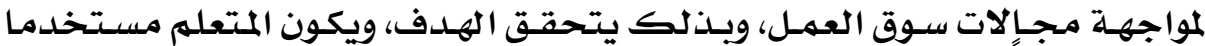

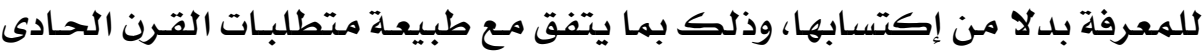
والعشرين.

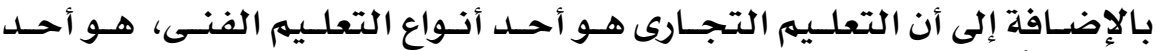

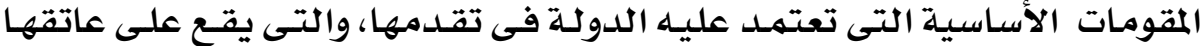

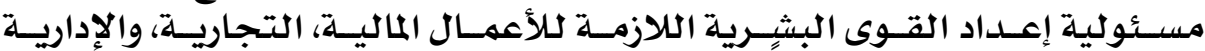

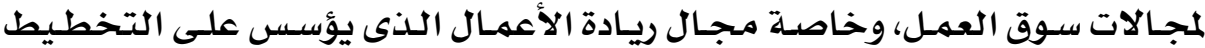

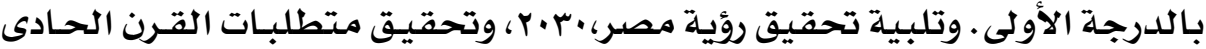




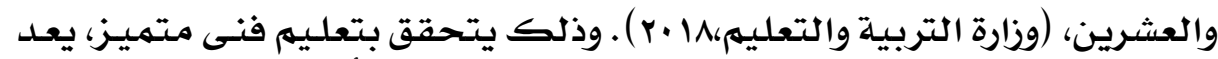

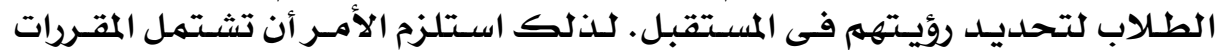

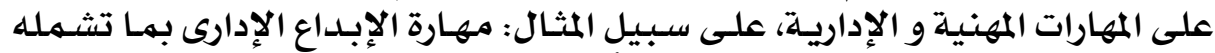

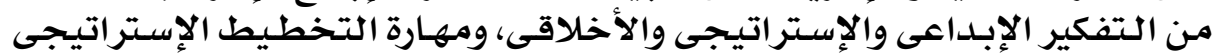

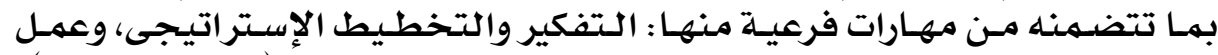

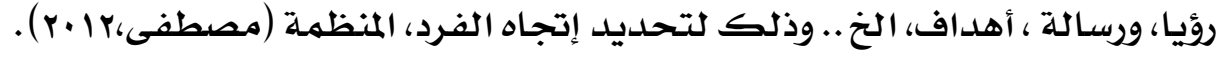

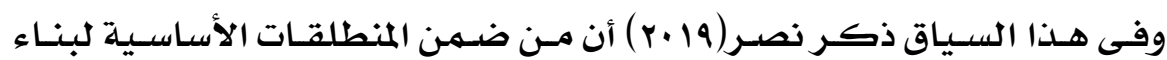

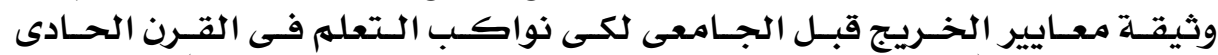

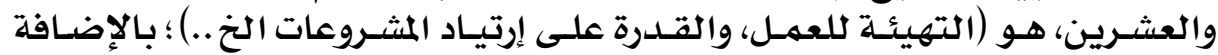

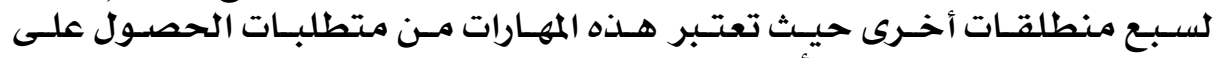

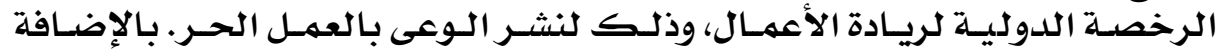

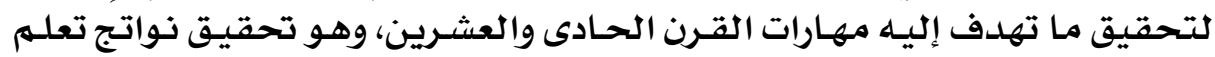

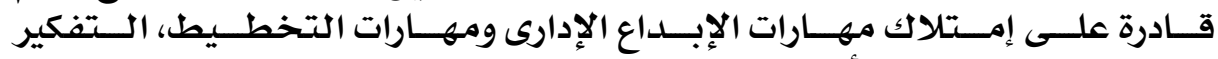

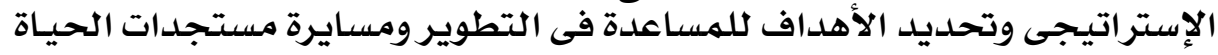

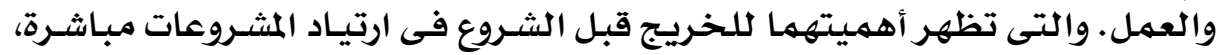

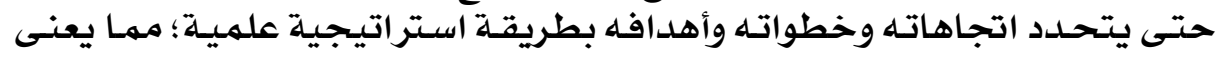

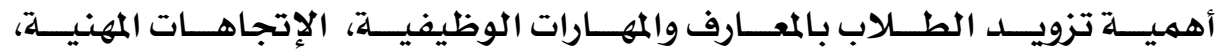

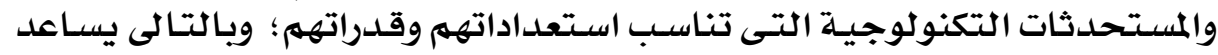

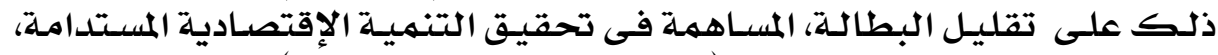

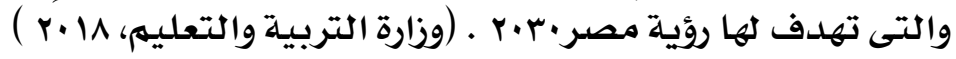

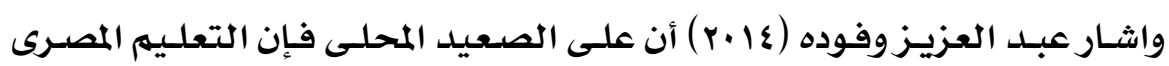

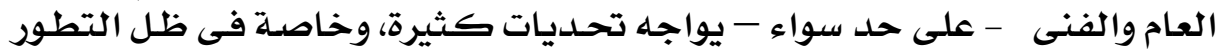

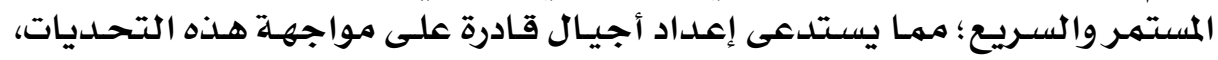

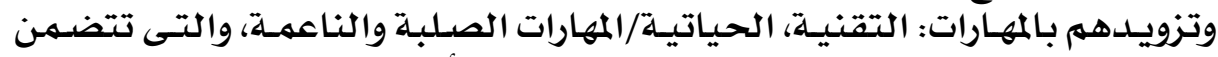

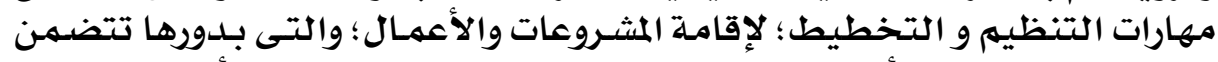

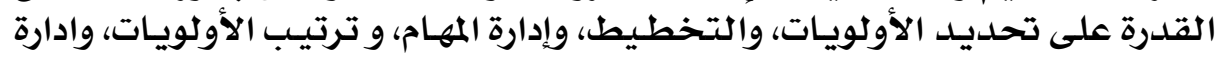

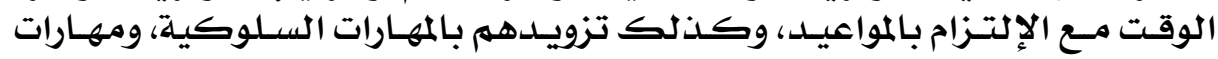

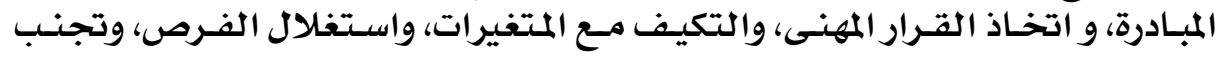

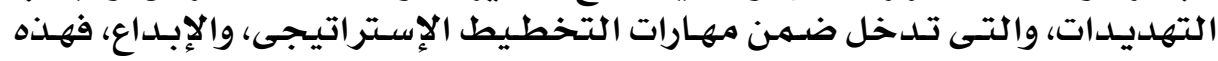

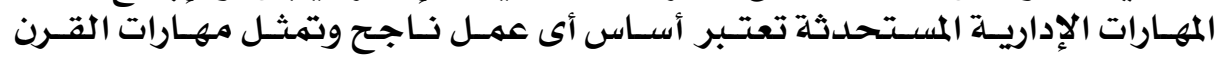

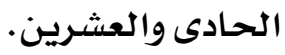

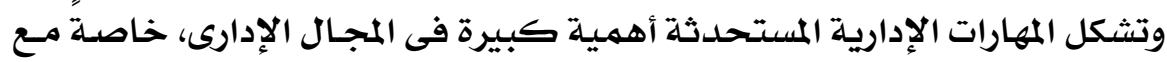

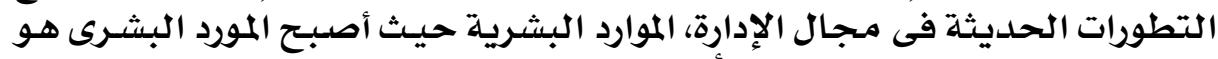

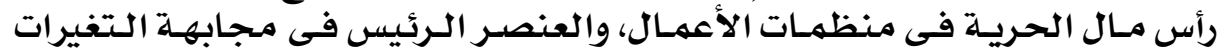

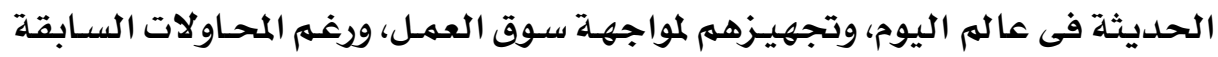

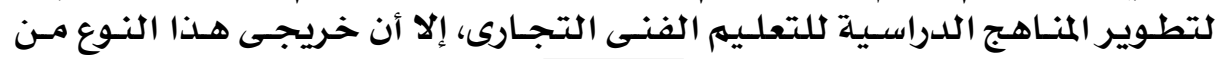

\section{YV}




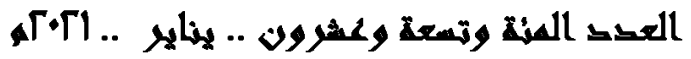

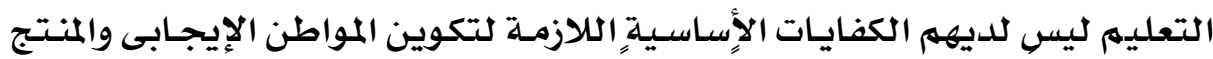

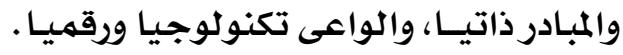

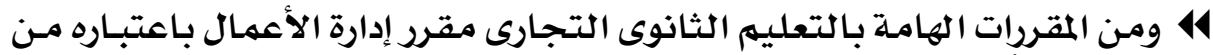

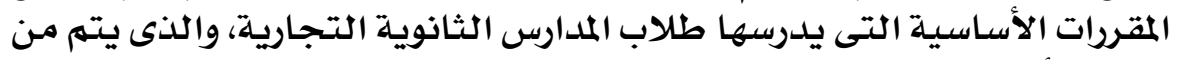

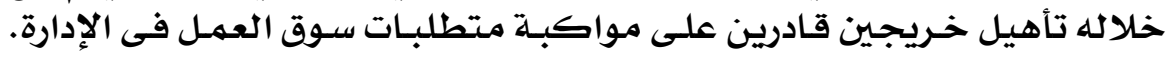

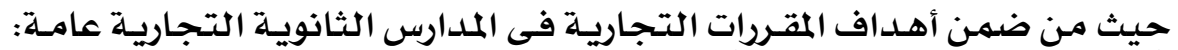

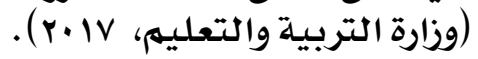

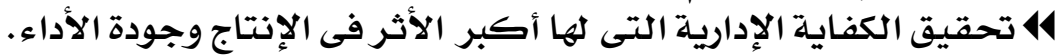

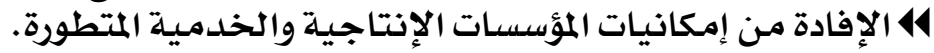

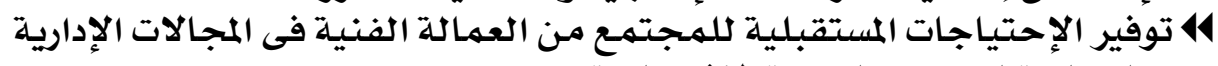

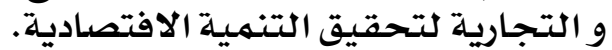

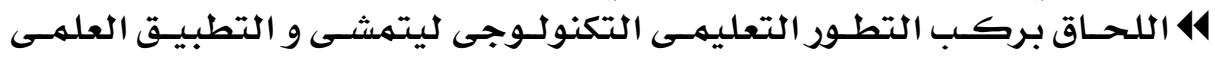

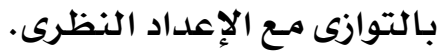

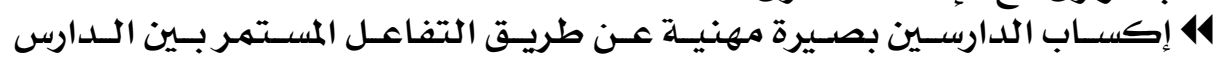
ومجالات العمل.

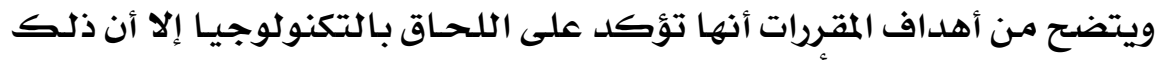

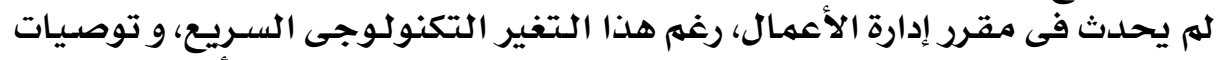

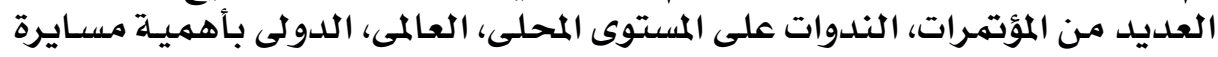

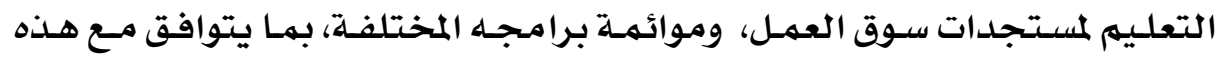

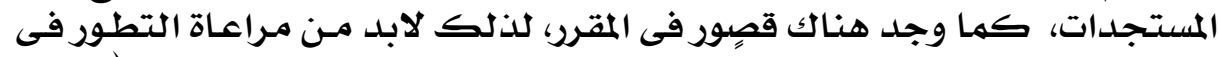

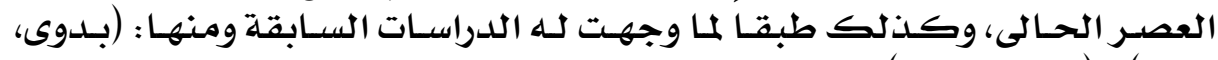

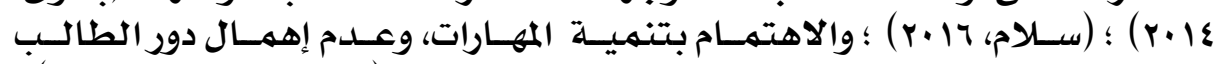

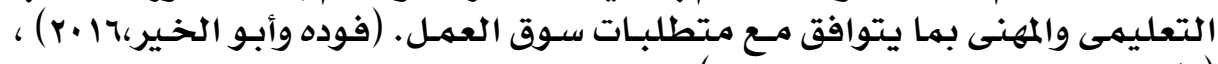

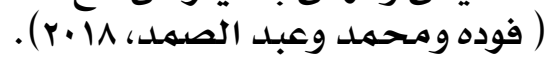

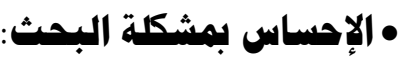

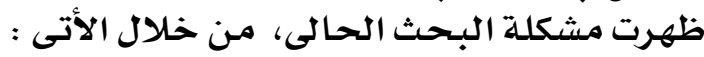

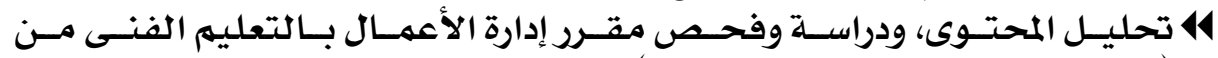

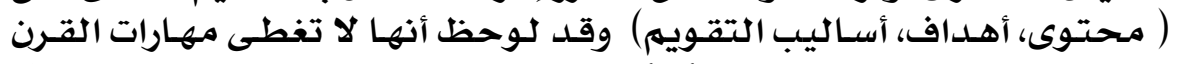

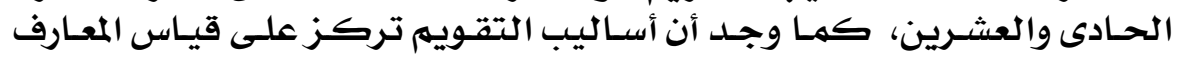
دون المهارات.

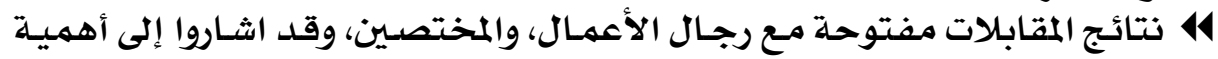

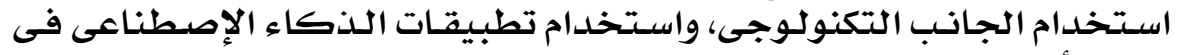

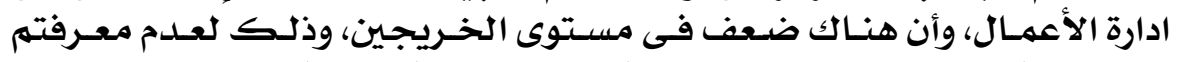

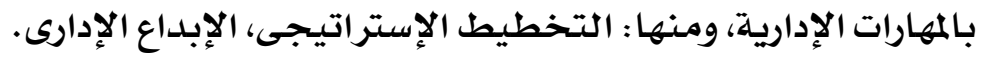

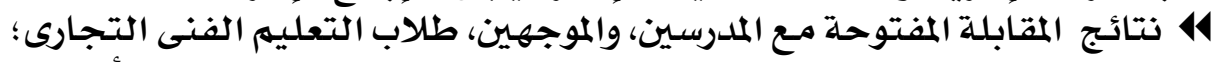

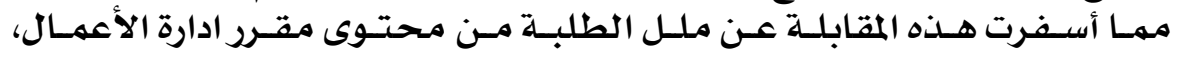

\section{Y $A$}




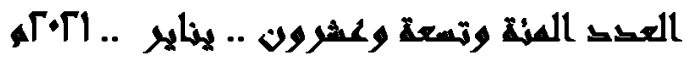

واعتماد المنهج على الحفظ والتلقين، بالاضـافة إلى إفتقاره إلى المهارات الإداريـة

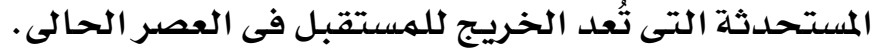

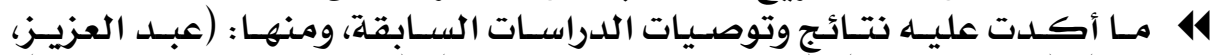

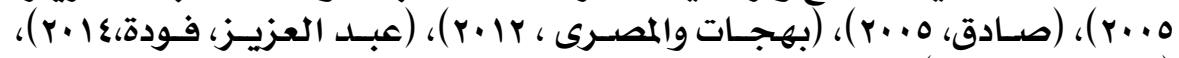

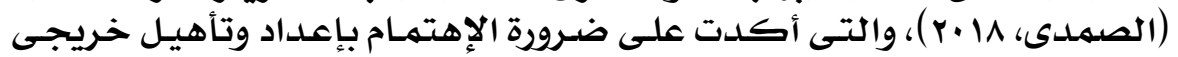

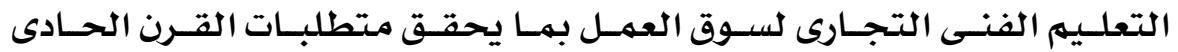
والعشرين.

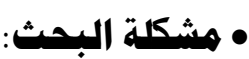

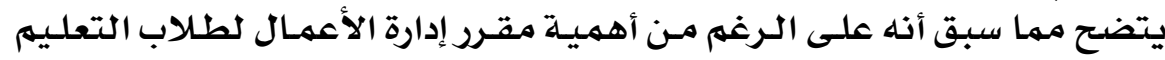

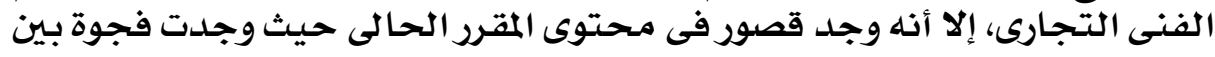

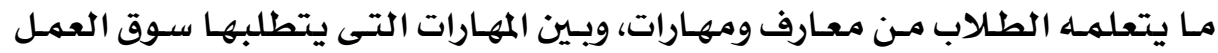

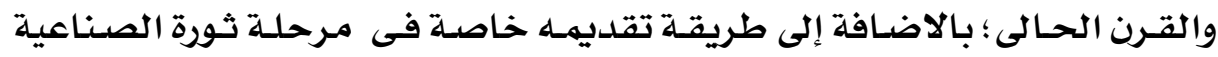

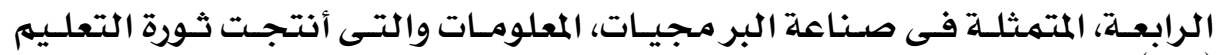

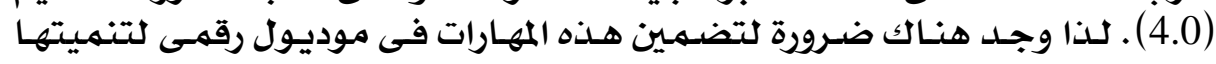

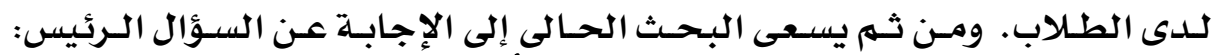

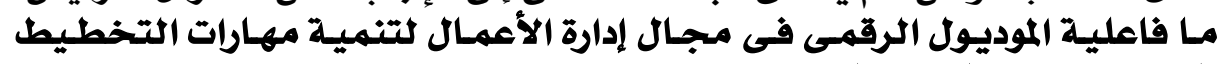

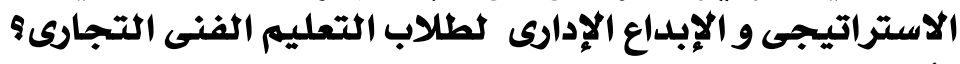

وينبثق من السؤال الرئيس الأسئلة الفرعية التالية:

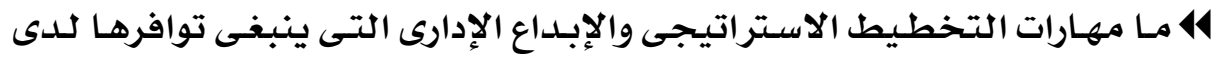

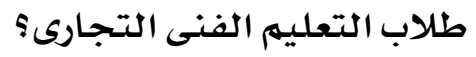

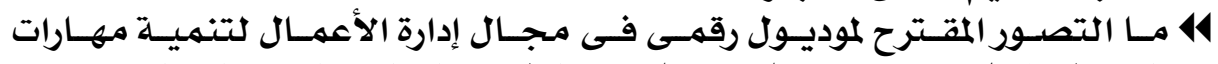

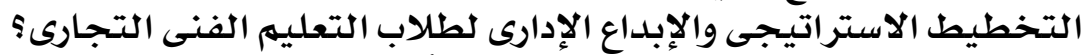

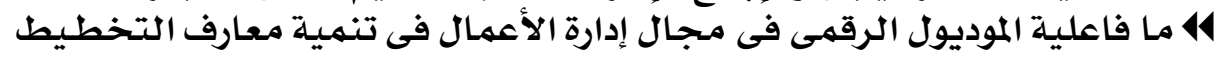

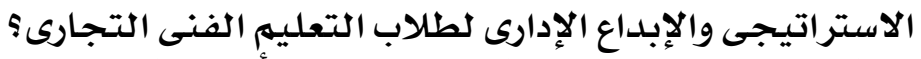

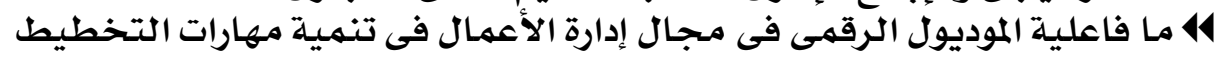

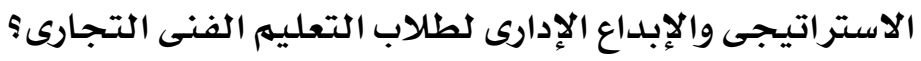

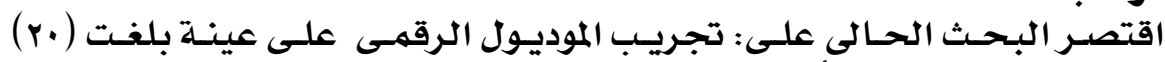

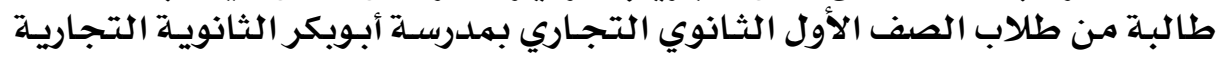
بنات، نظام الثلاث سنوات الهف، محافظة الاول الثانوي التجية.

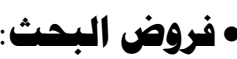

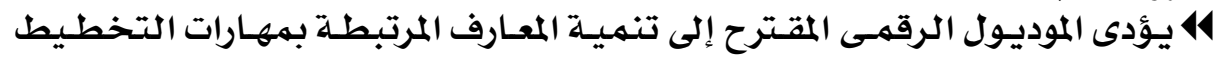

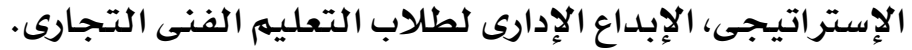

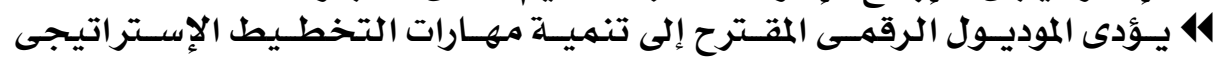

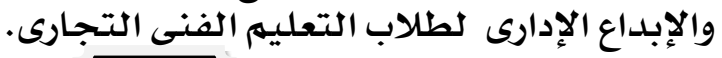

\section{rq}


41 تحديد قائمـة بهمارات التخطيط البح الاستراتيجى، الإبداع الإدارى لطلاب التعليهم

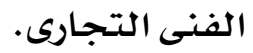

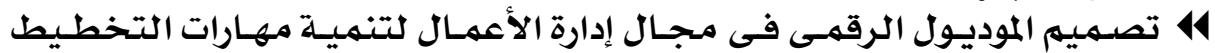

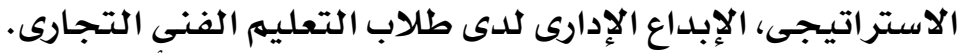

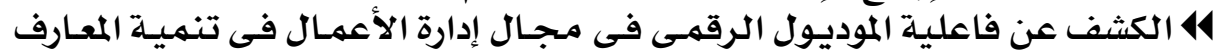

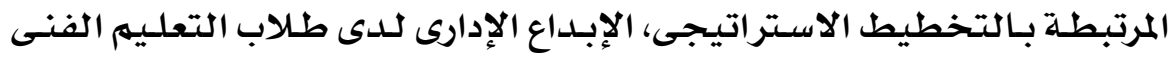
التجارى.

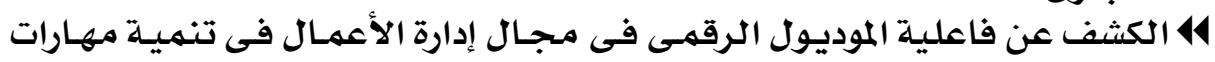

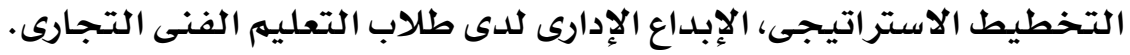

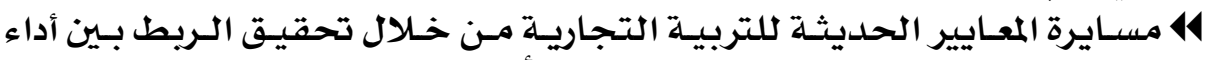

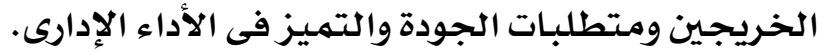

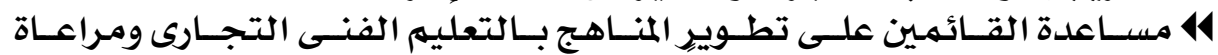

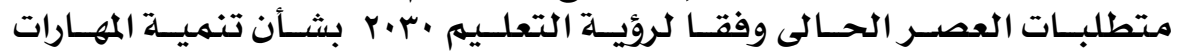
الوظيفية لدى الطلاب.

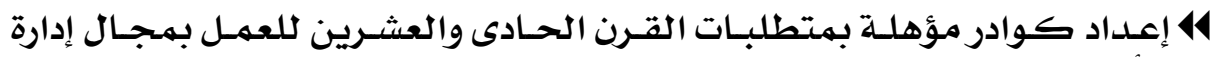

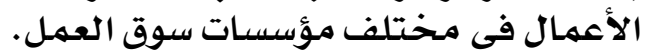

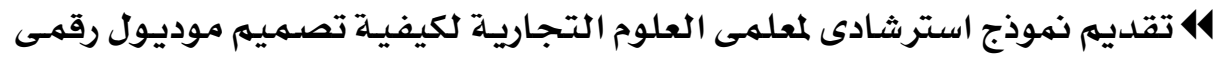

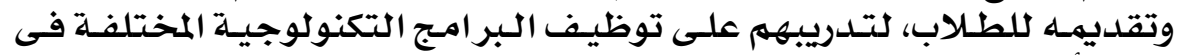

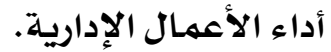

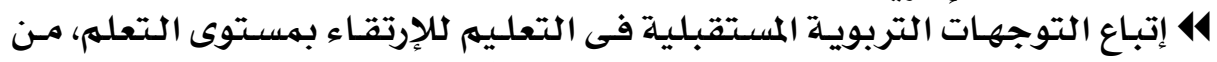

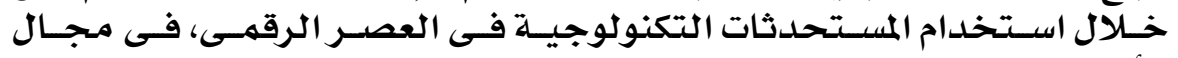

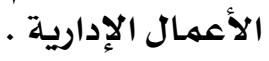

يتضمن البحث الحالى المثير المتغيرات التالية:

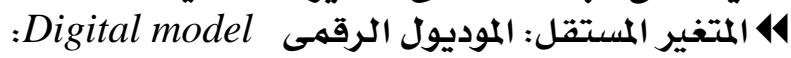

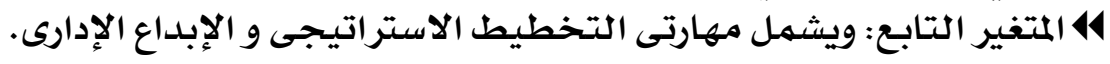

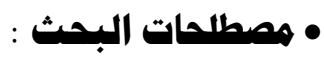

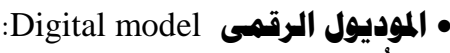

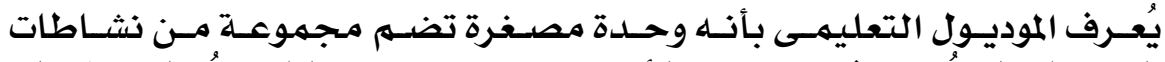

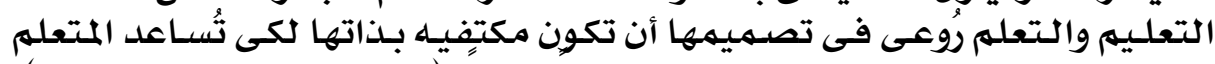

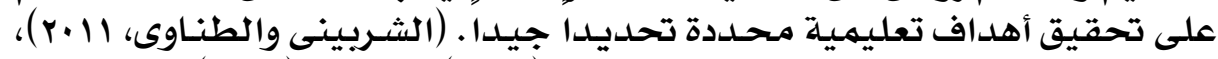

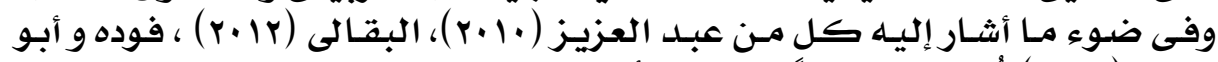

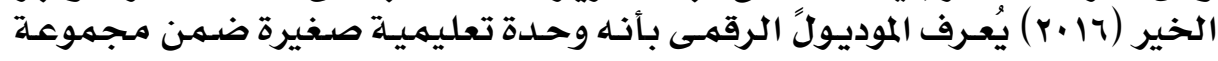

\section{$\boldsymbol{r}$}




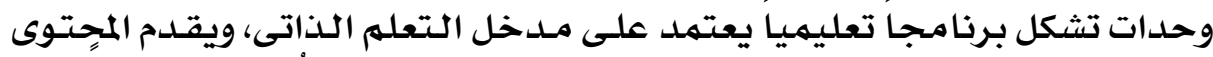

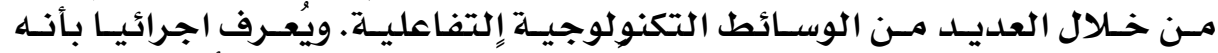

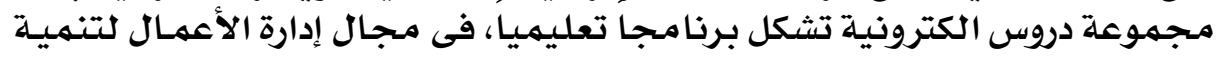

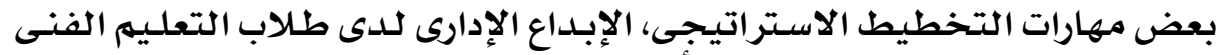

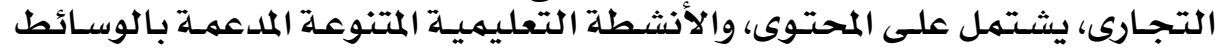

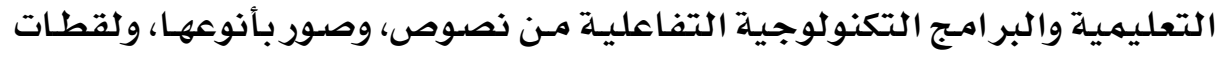

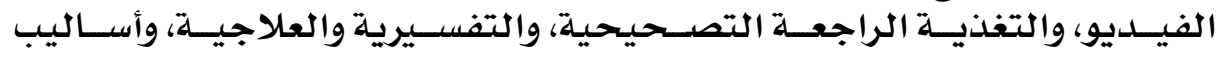
التقويه.

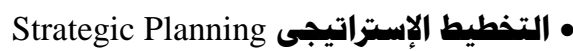

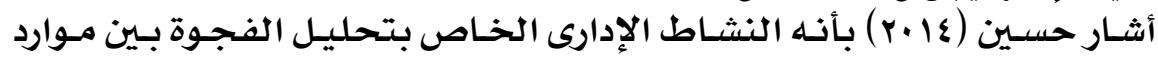

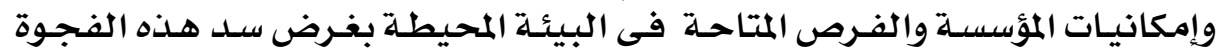

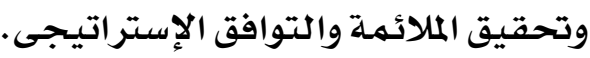

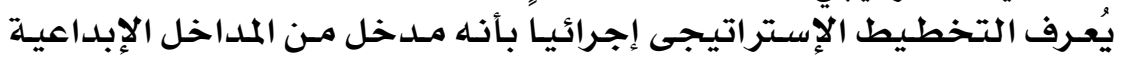

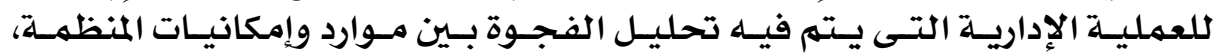

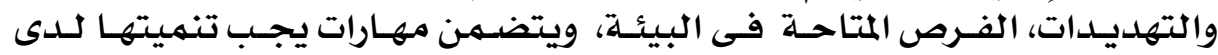

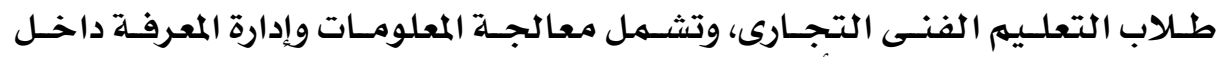

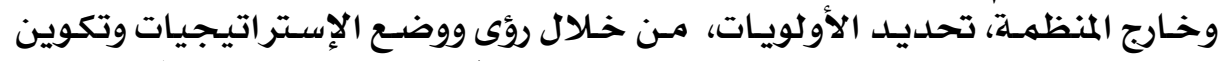

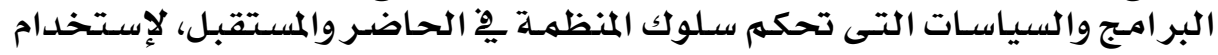

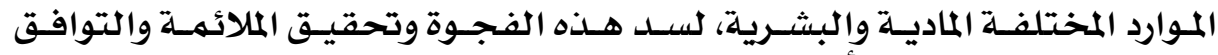

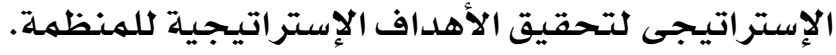

• • الإبداع الإدارى Administration Creativity:

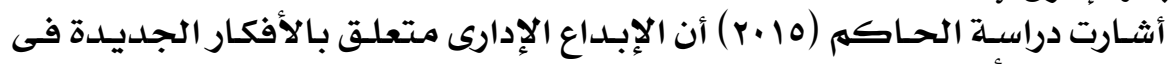

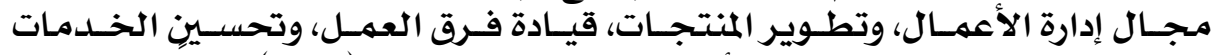

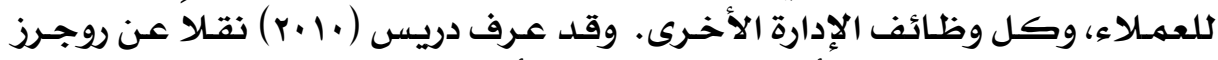

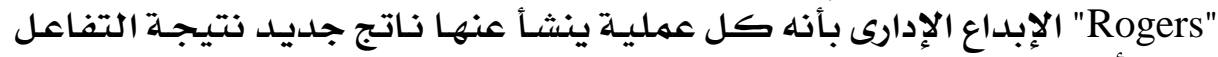

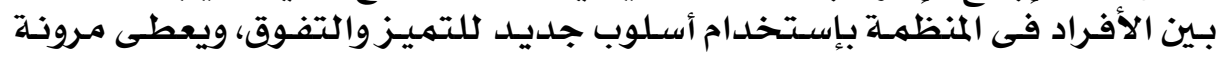
أكبر داخل المنظمهة.

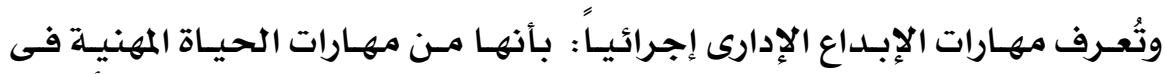

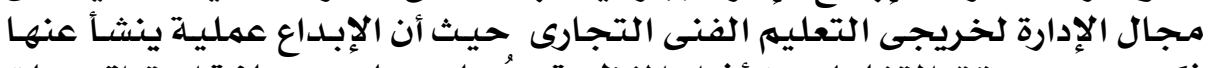

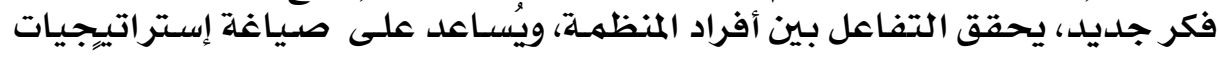

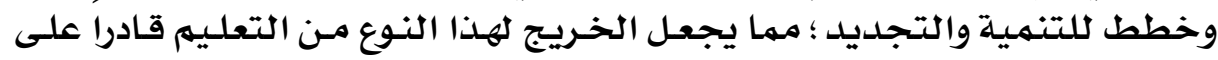

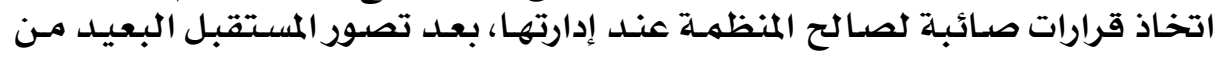

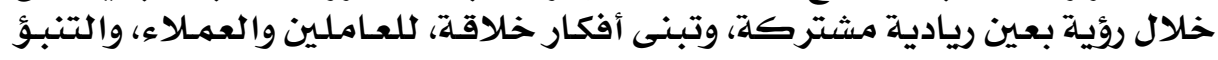

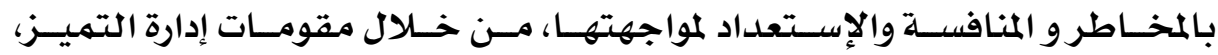

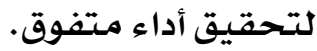




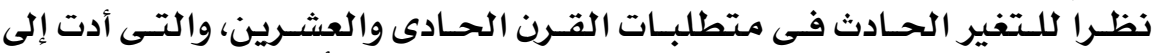

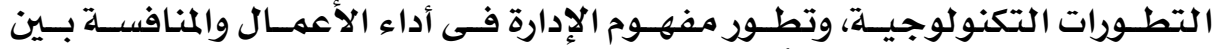

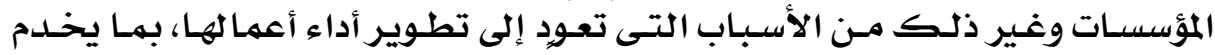

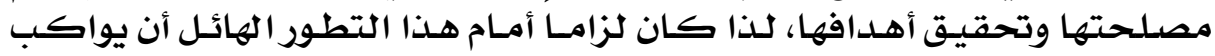

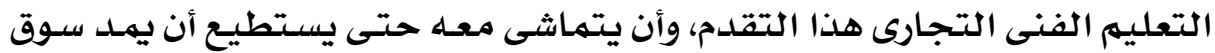

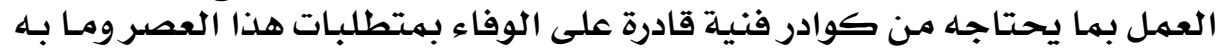

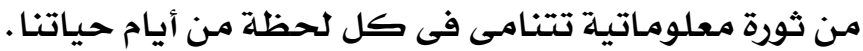

\section{• المعور الأول : همارات التخطيط الإستزاتيبمي:}

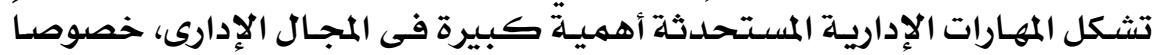

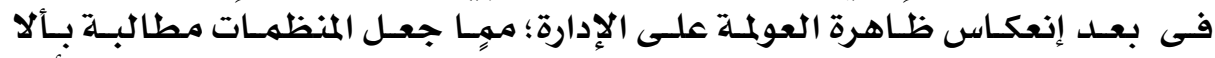

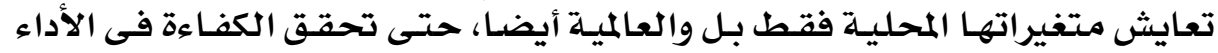

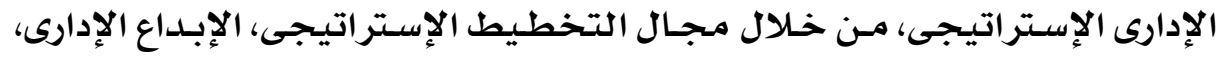

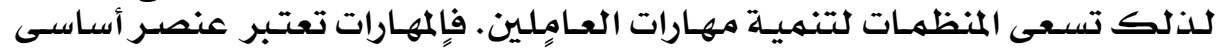

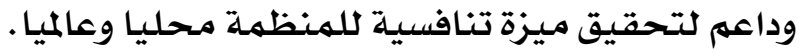

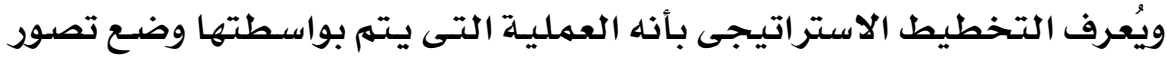

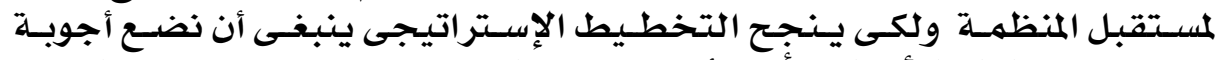

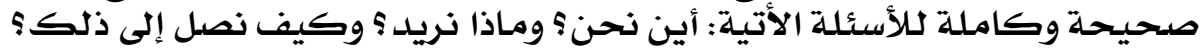

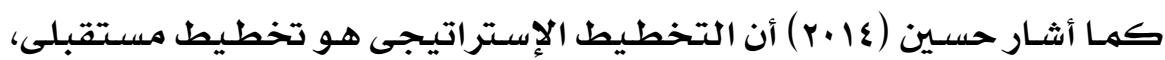

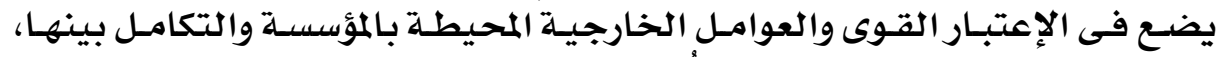

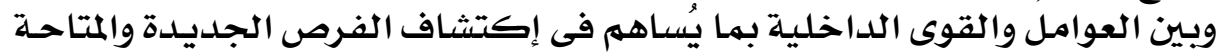
فى المستتقبل.

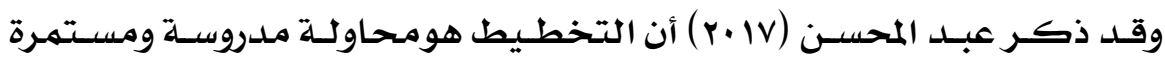

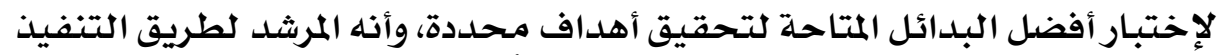

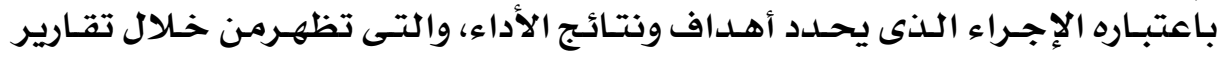
النشاطات.

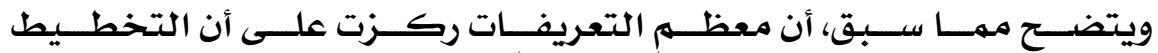

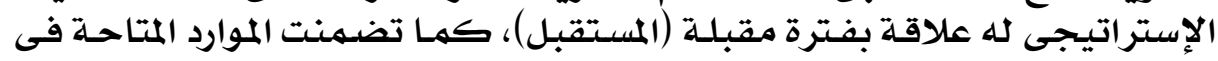

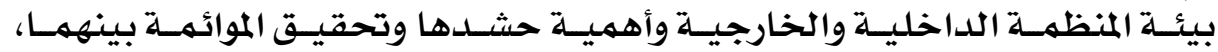

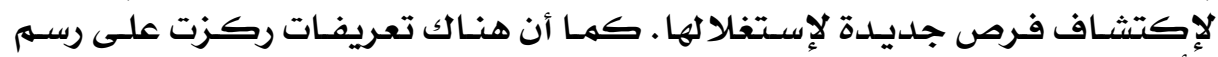

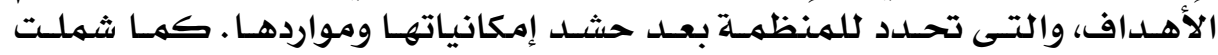

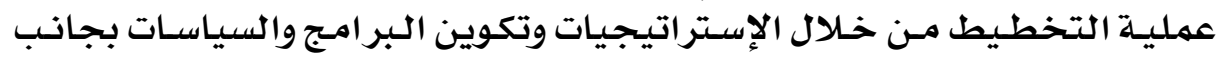
الموارد .

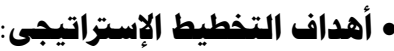

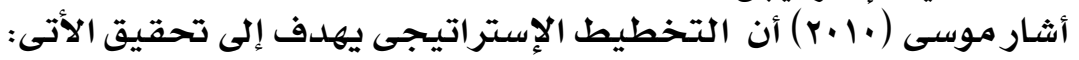




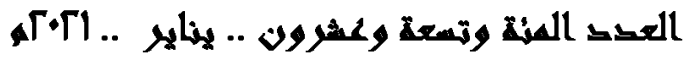

14 نظرة مستقبلية لتحقيق الرؤية، من خلال خطلة عامـة طويلـة المدى تبـين المهام

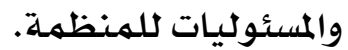

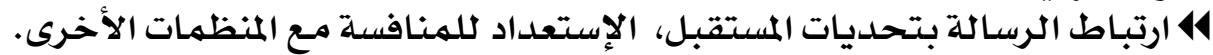

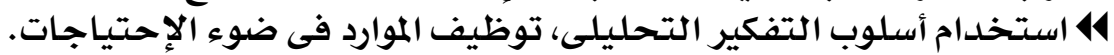

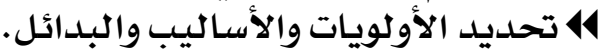
44 التعرف على نقاط القوة والضعف في في المنظمية.

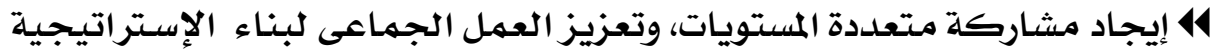

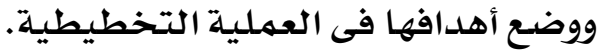

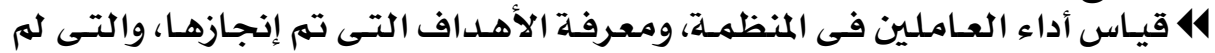
تتمم انجازها.

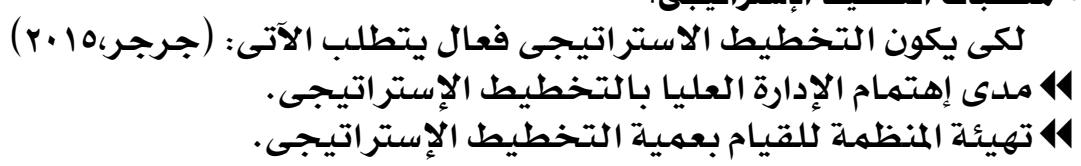

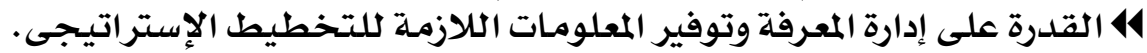

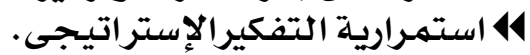

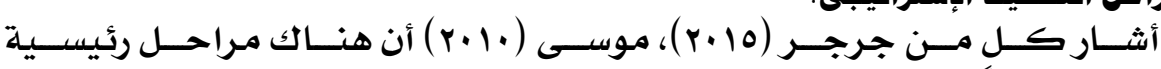

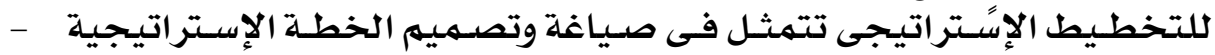

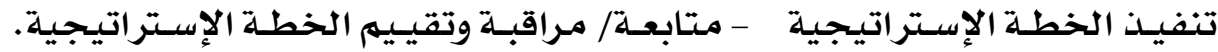

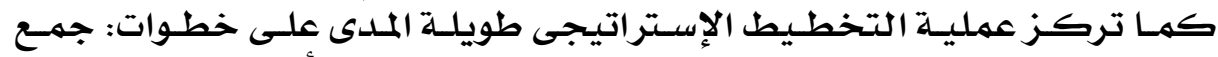

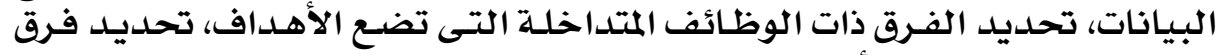

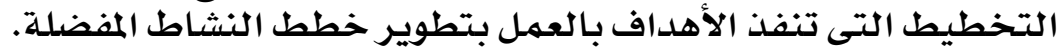

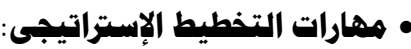

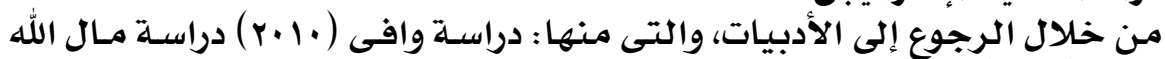

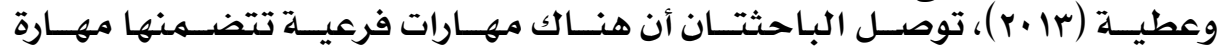

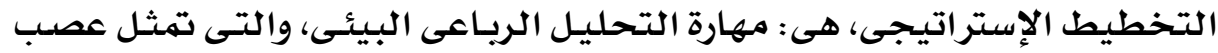

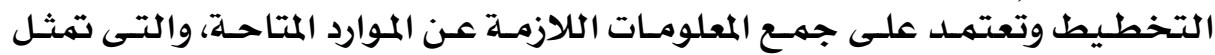

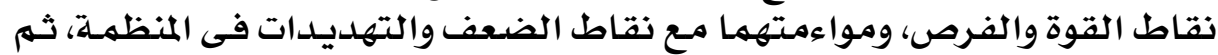

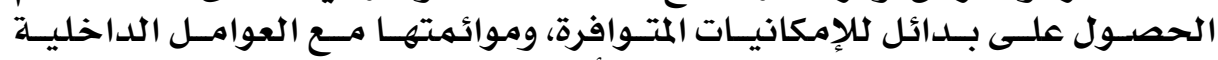

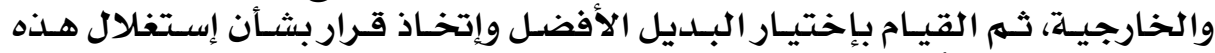

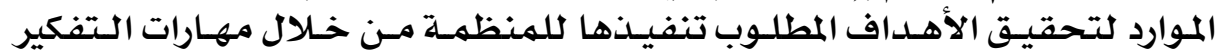

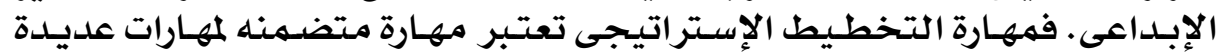

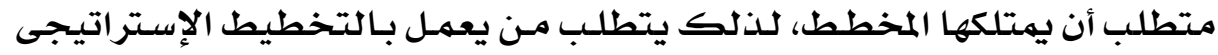

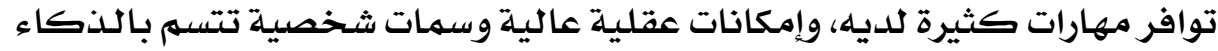

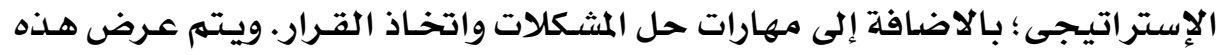

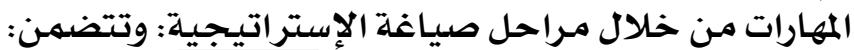

\section{Yr}




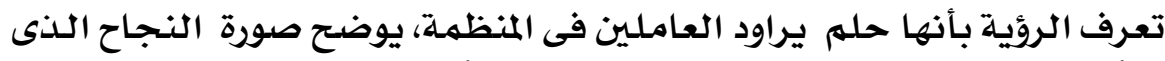

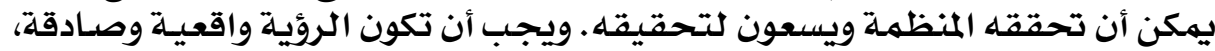

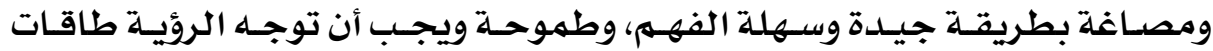

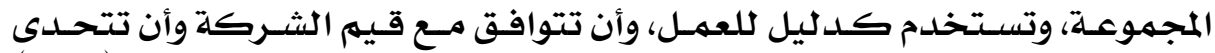

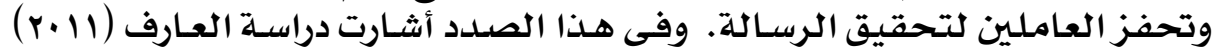

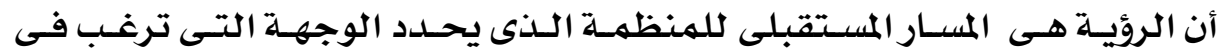

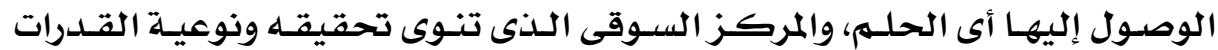

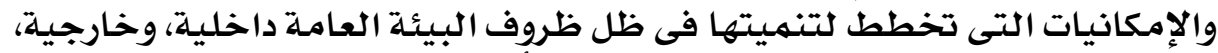

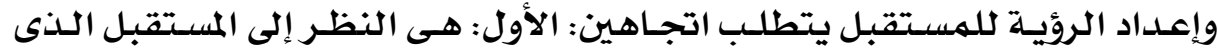

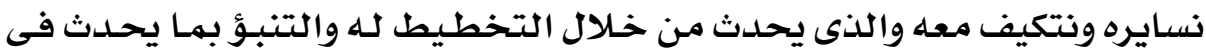

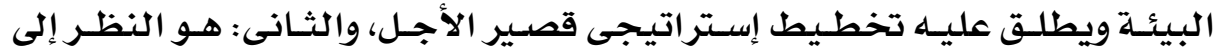

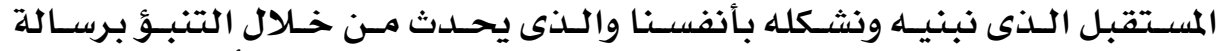

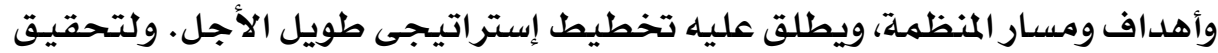

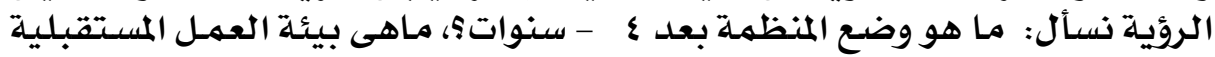

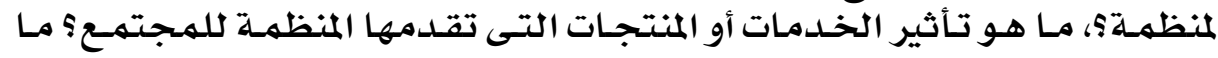

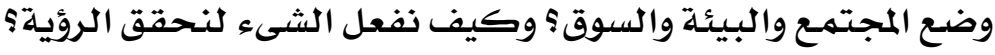

r - إعداد الرسالة والتى توضع عدة عناصر أهمها:

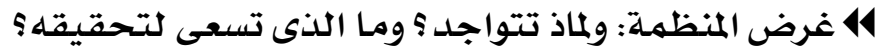

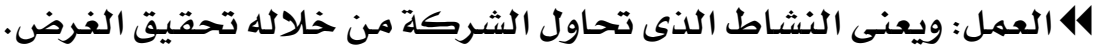

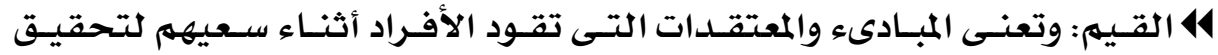

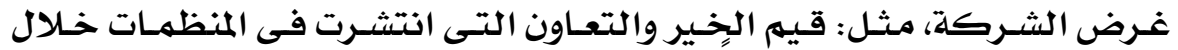

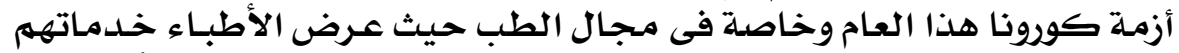

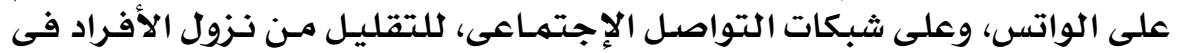

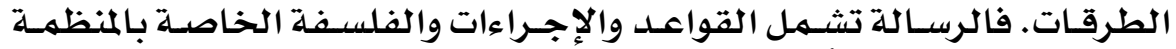

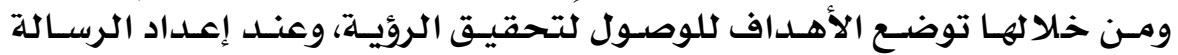

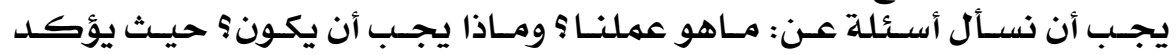

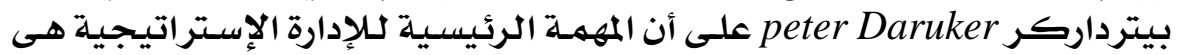

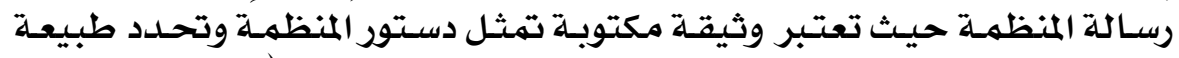

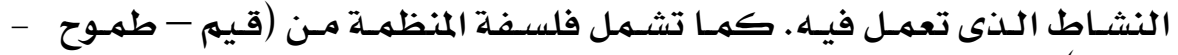

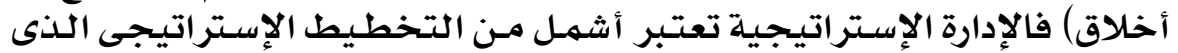

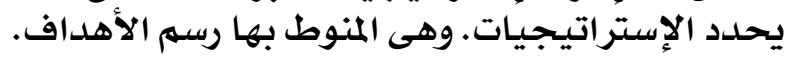

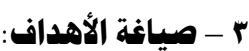

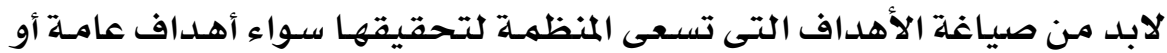

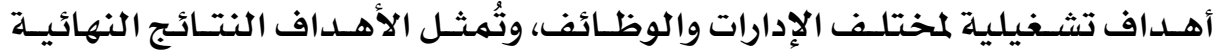

\section{$r \varepsilon$}




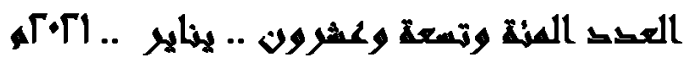

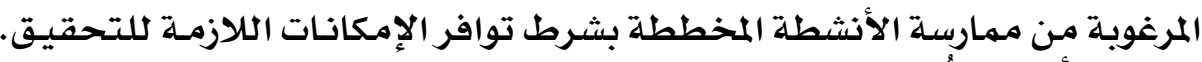

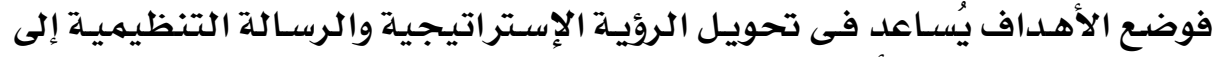

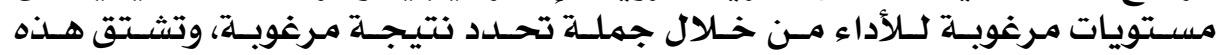

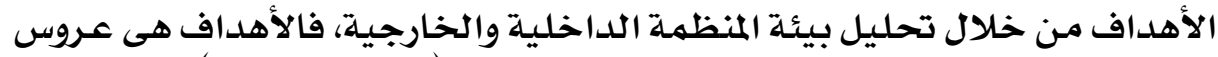

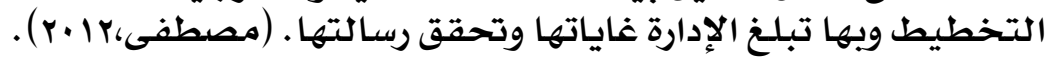

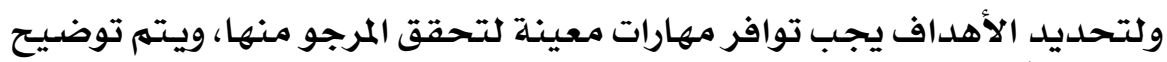
أنواعها كالآتى :

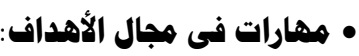

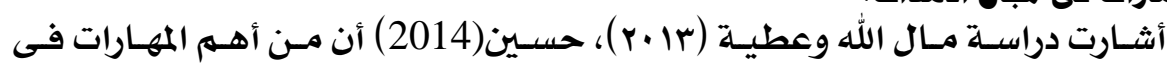

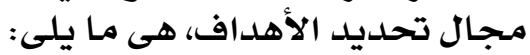

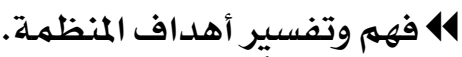

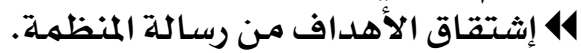

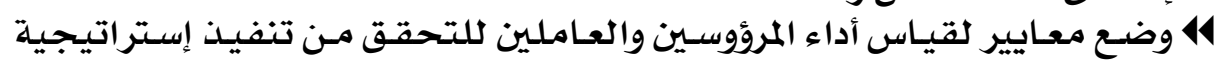
المنظمة.

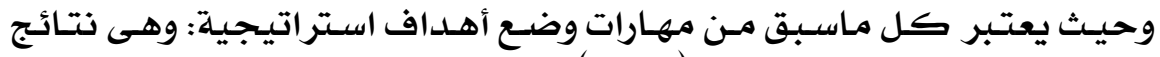

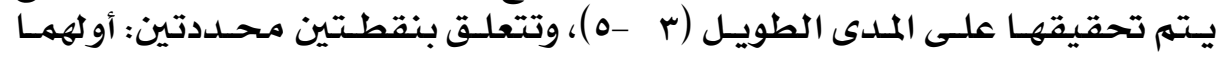

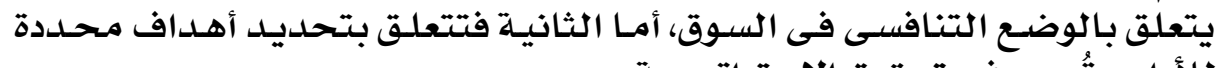

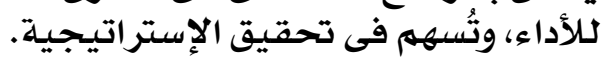

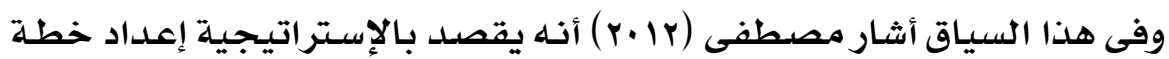

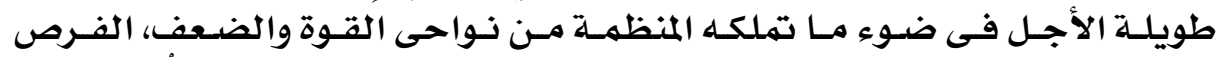

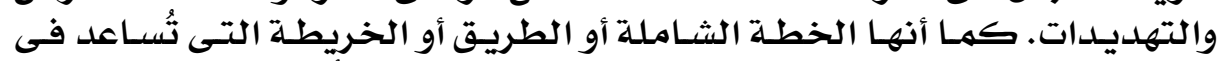

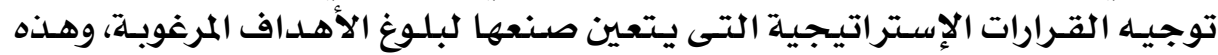

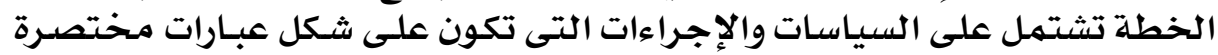

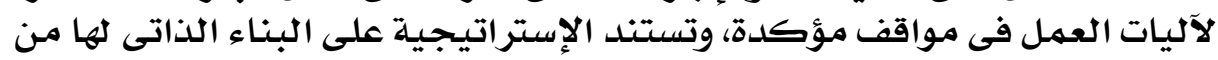

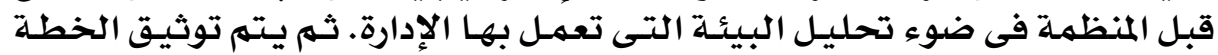

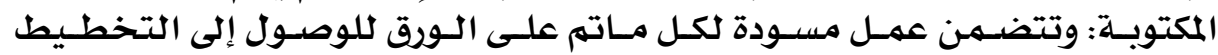

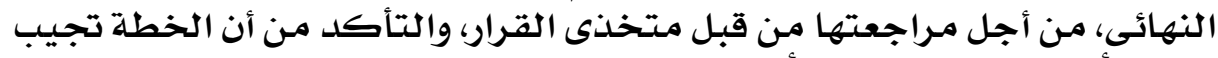

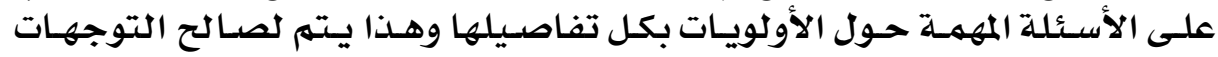

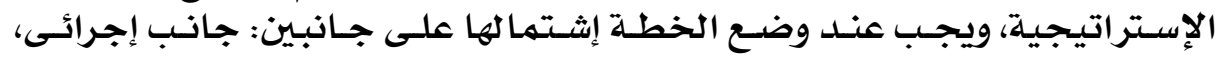

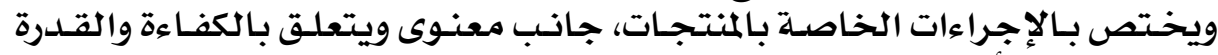

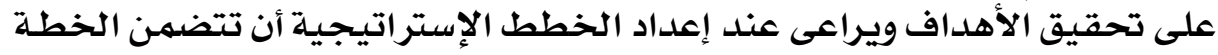

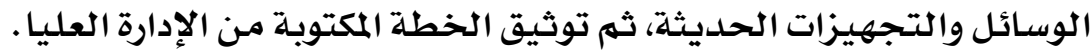

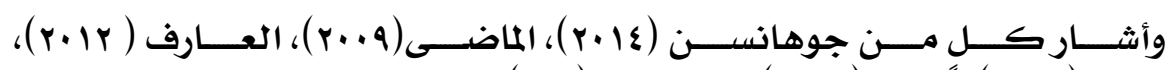

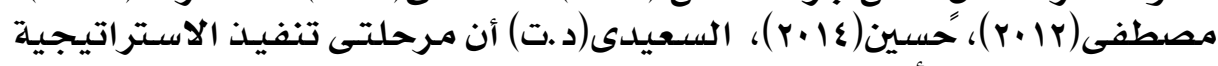
وتقويهها تتضمن (r)، آلأتى: 


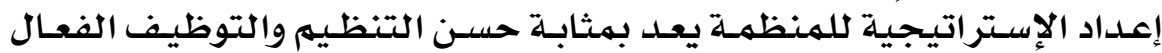

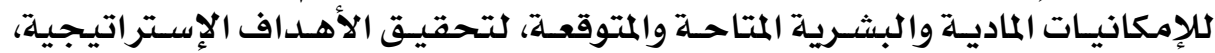

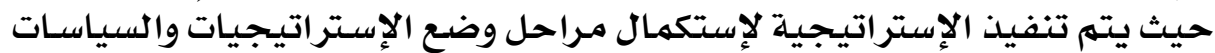

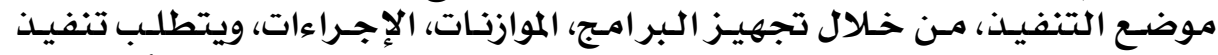

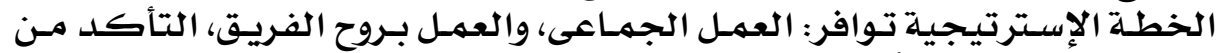

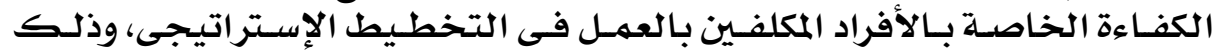

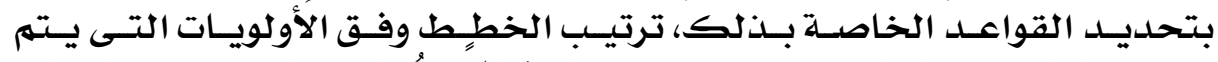

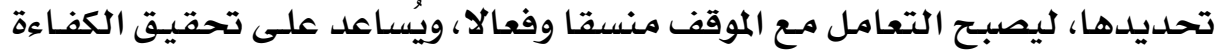

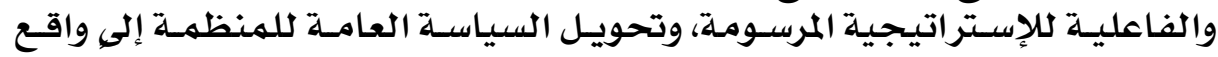

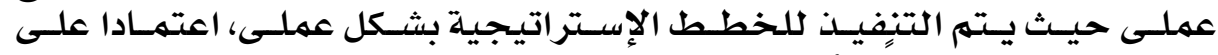

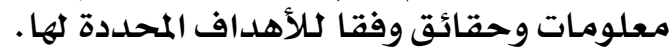

• المرحلة الثالثة: تقييم الإستراتيجية:

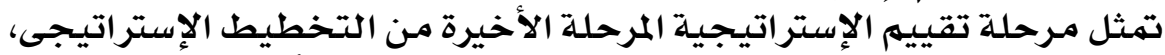

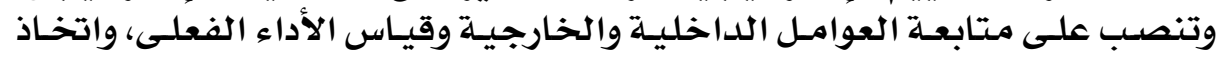

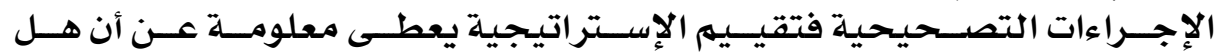

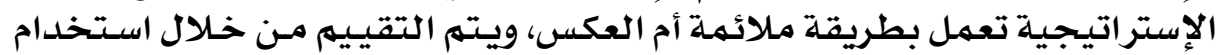

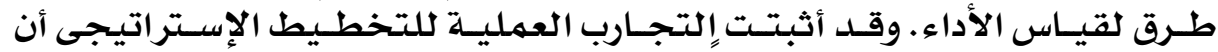

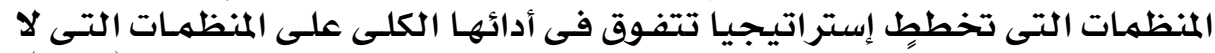

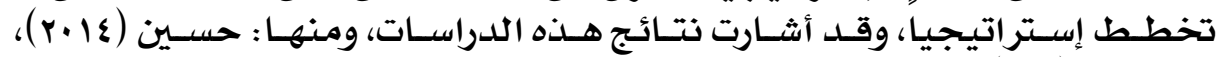

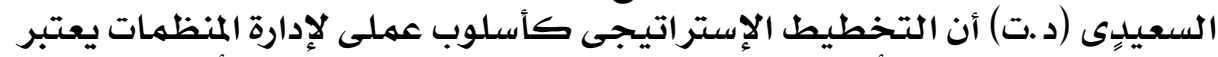

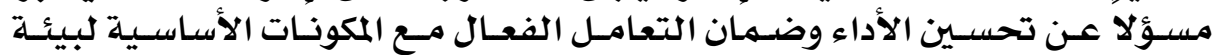

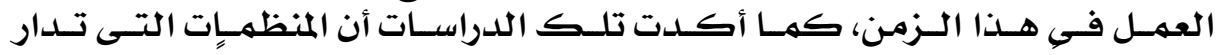
إستراتيجيا تهتعت بأداء يفوق أداء المنظمات التى لا تدار إستراتيجيا .

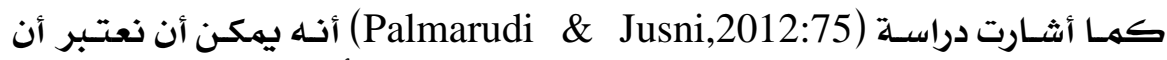

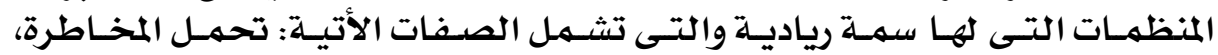

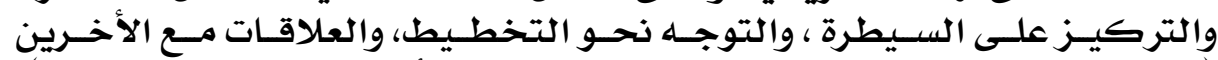

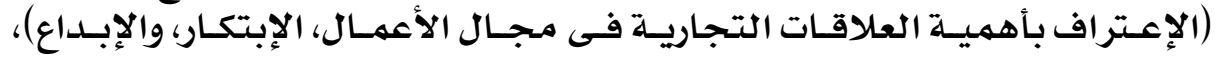

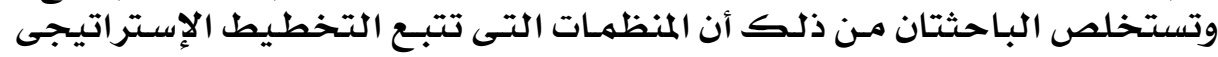

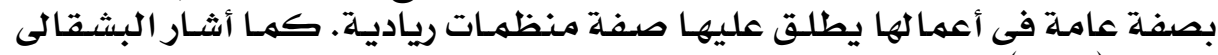

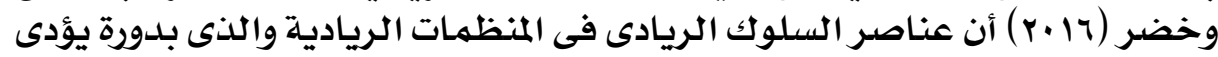

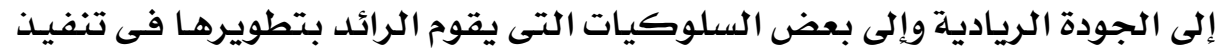

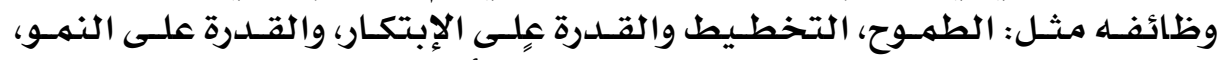

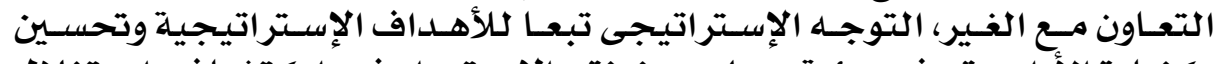

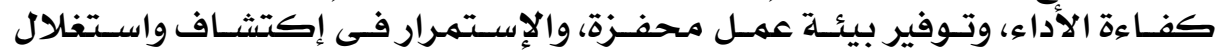

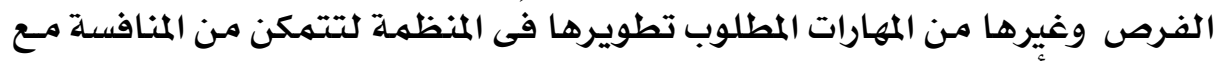
المنظهات الأخرى وعرى

\section{4}




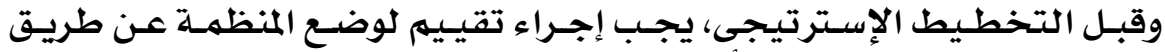

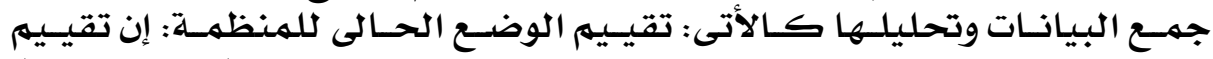

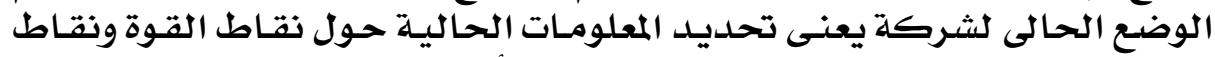

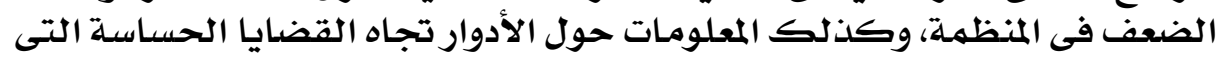

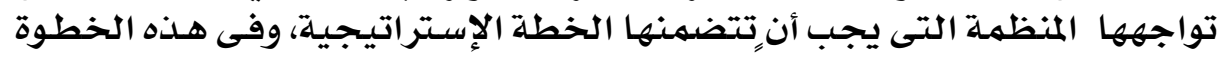

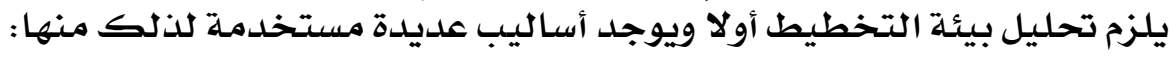

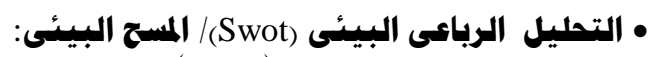

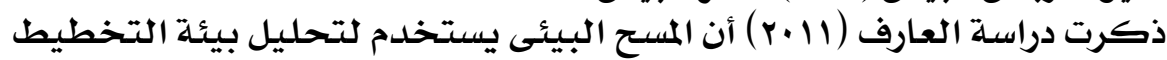

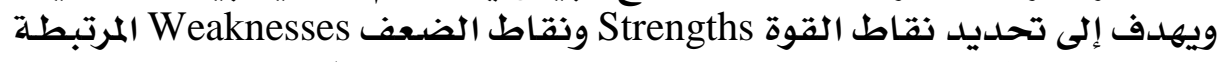

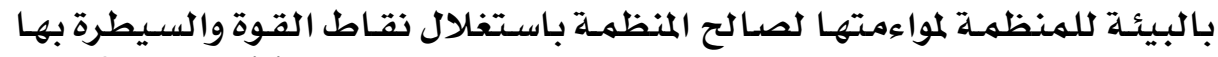

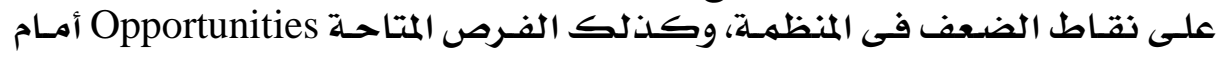

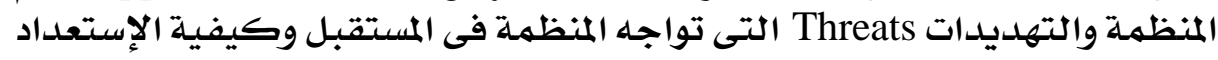

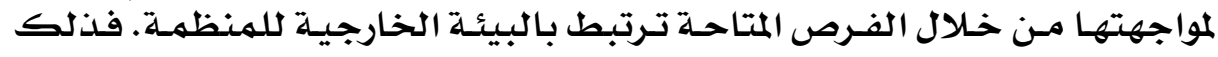

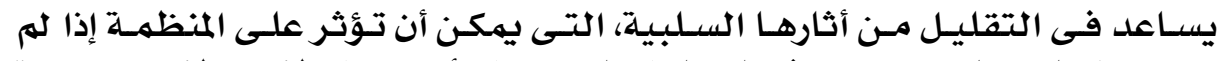

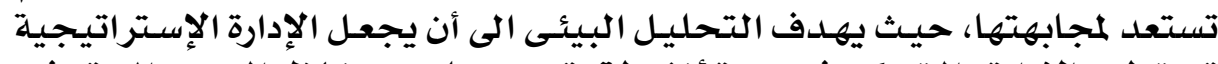

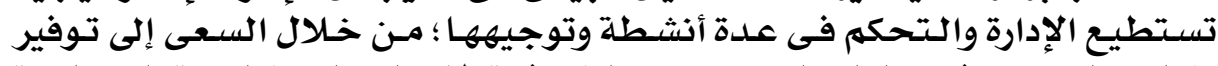

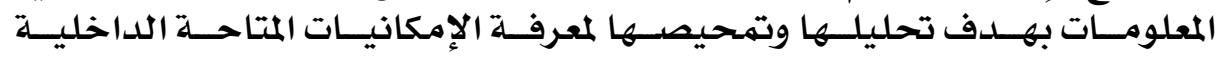
والخارجية للمنظمهة.

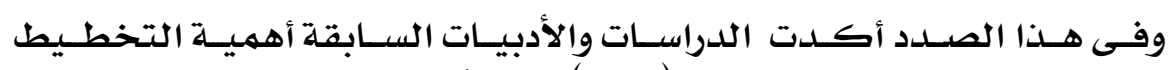

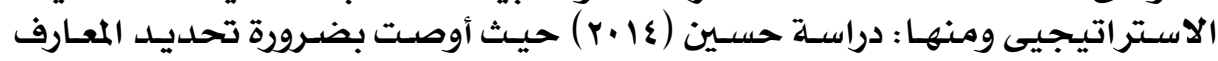

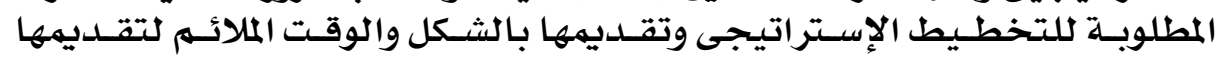

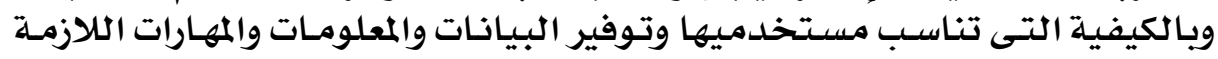

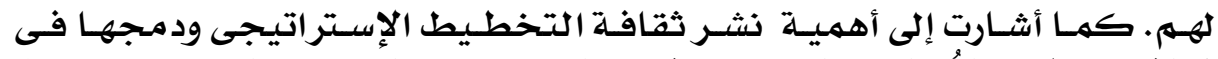

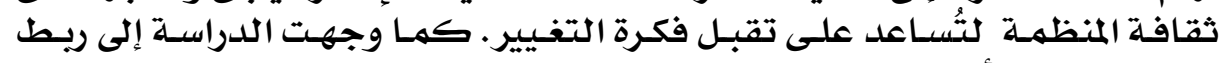

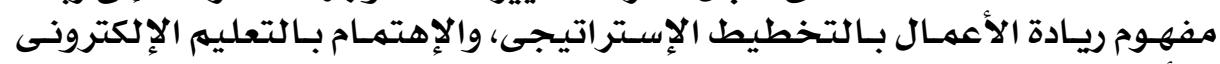
كأحد أدوات نشر المعرفة

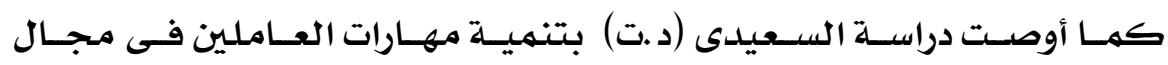

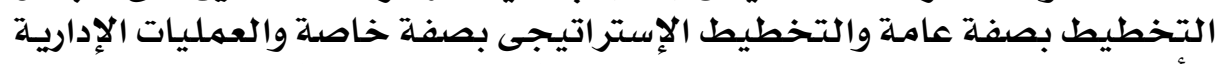

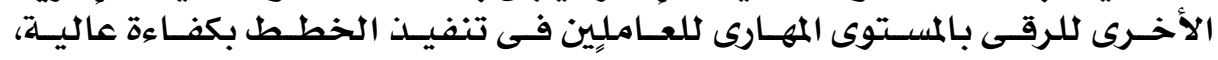

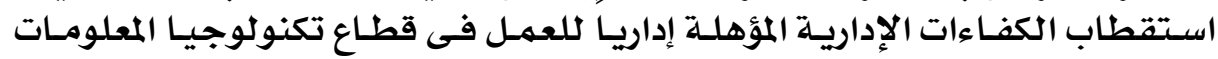

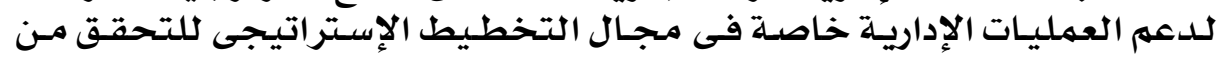

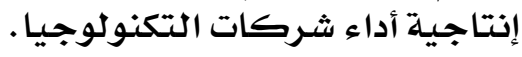

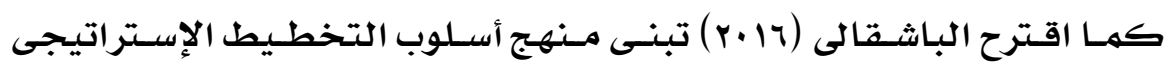

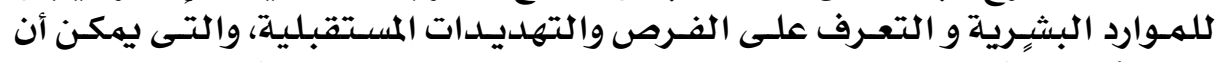

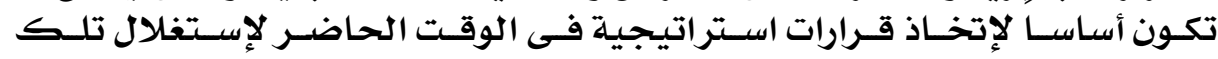




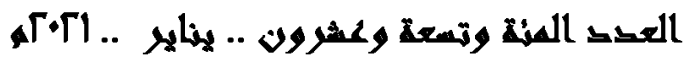

الفـرص، وتجنـب تلـك التهلديـات، كهـا أن التخطـيط يعنى تصسميهم مسـتقبلى فيلى

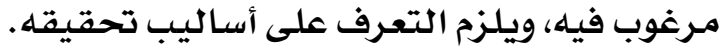

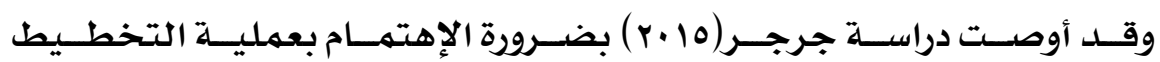

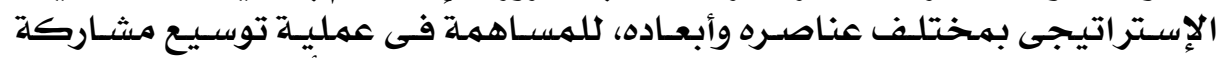

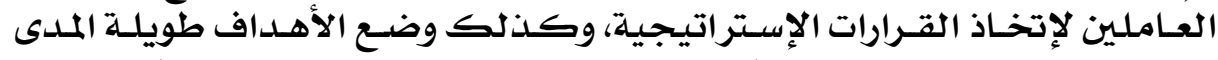

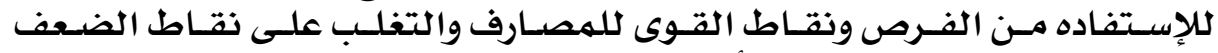

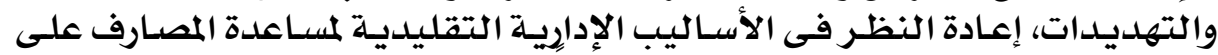

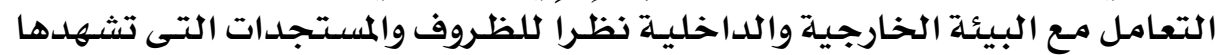
انبلاد.

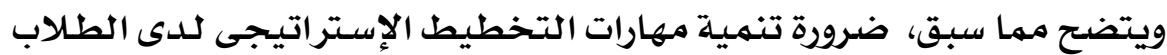

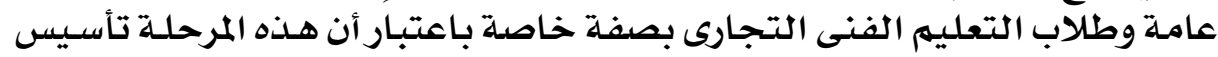

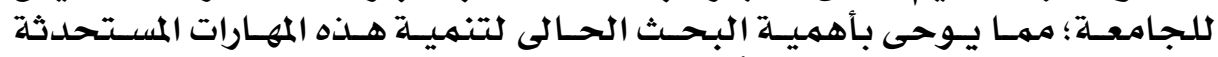

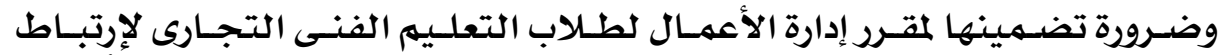

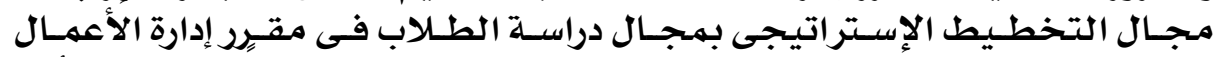

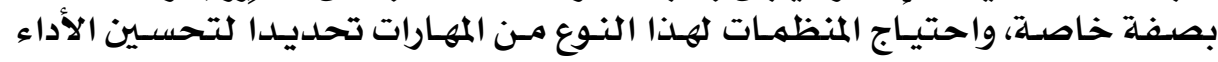

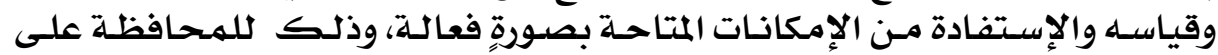

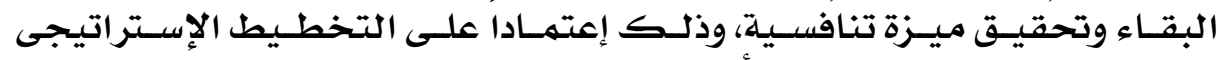

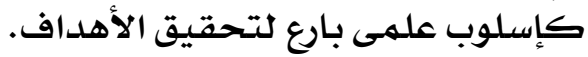

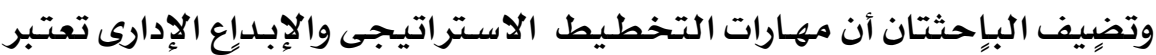

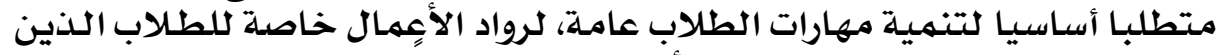

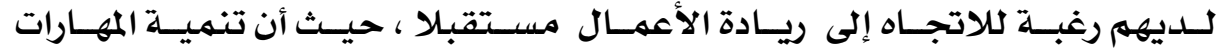

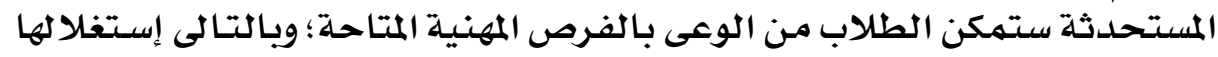

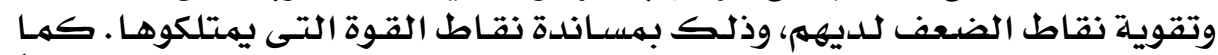

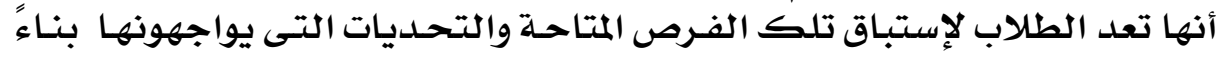

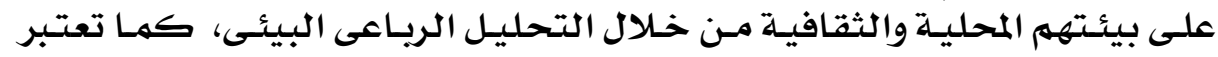

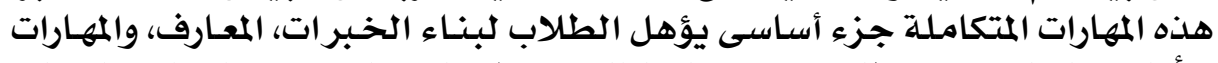

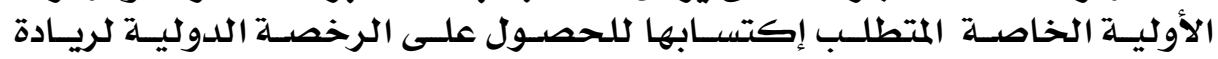

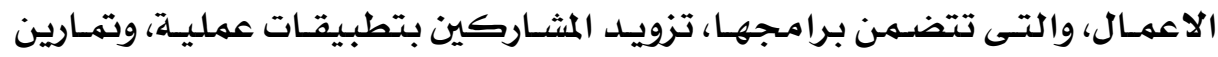

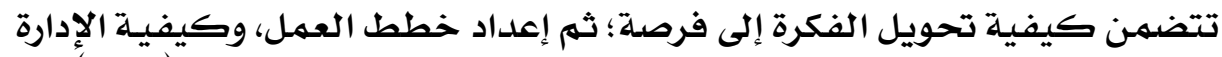

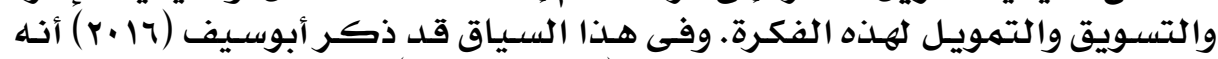

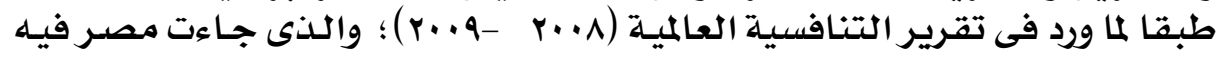

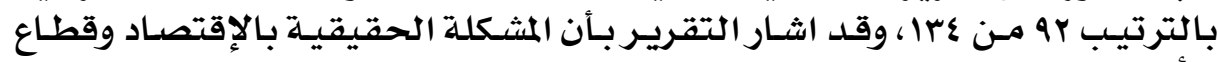

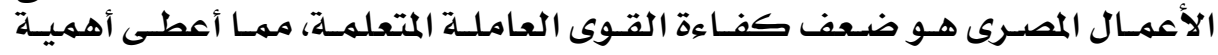

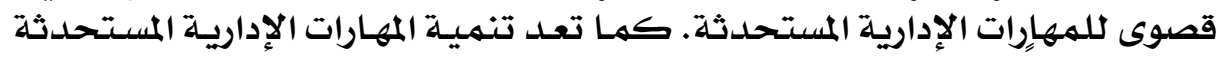

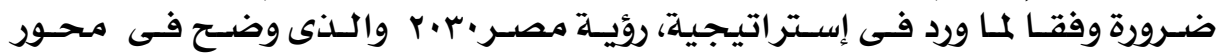

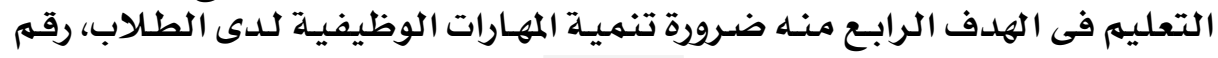

\section{rᄉ}




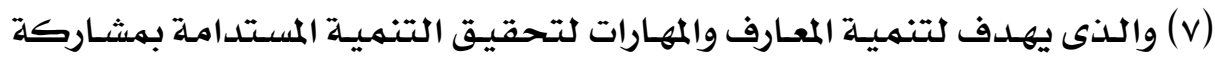

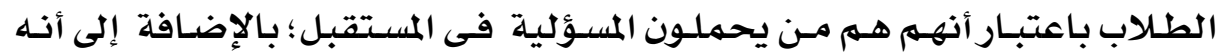

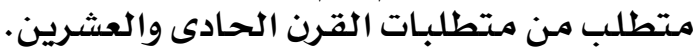

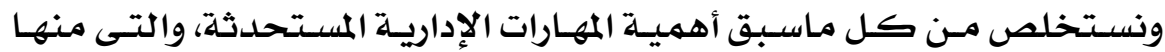

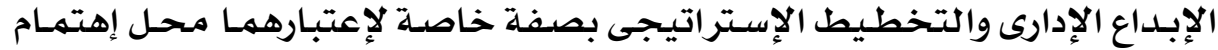

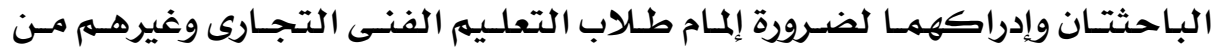

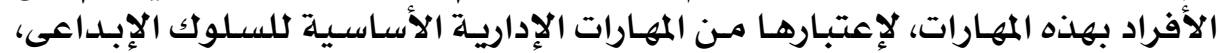

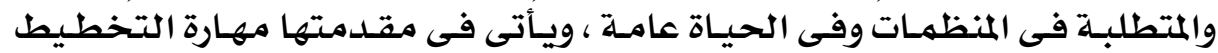

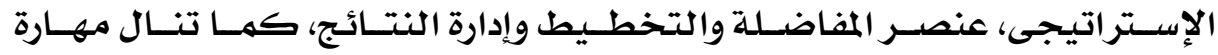

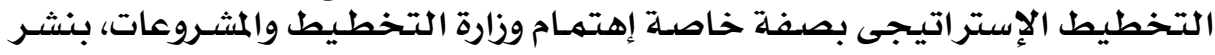

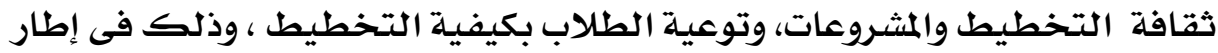

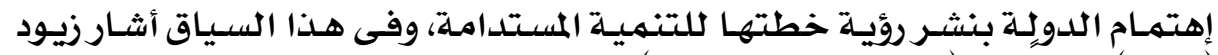

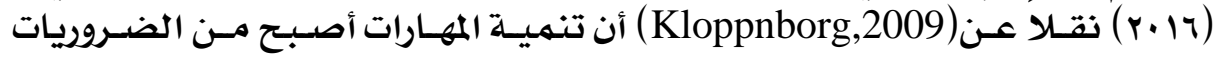

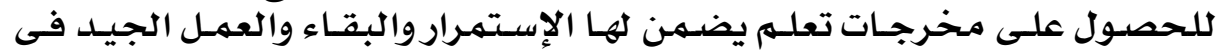

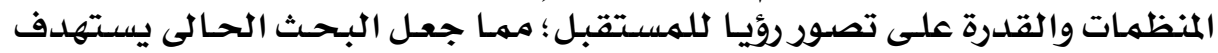

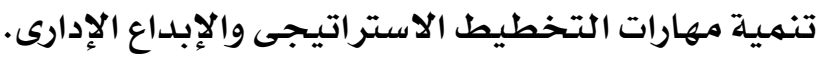

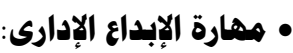

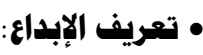

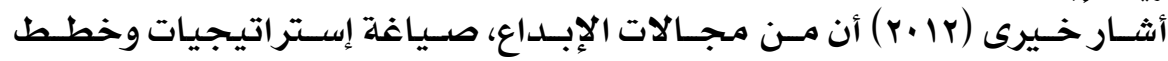

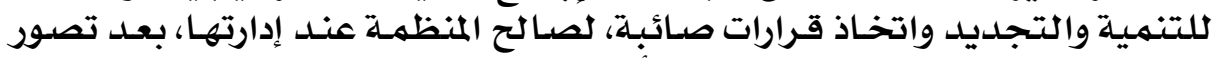

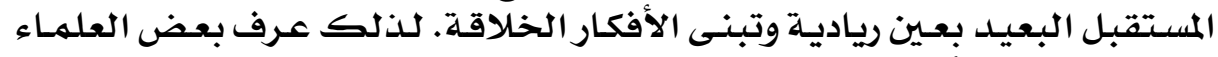

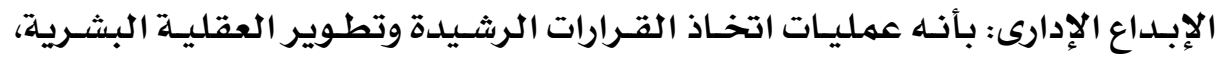

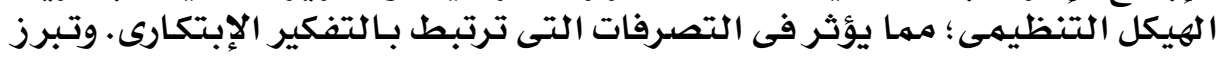

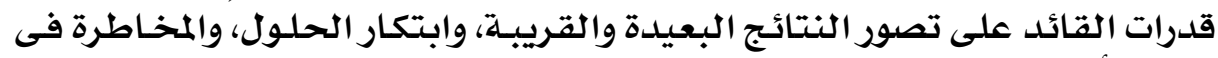

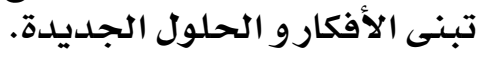

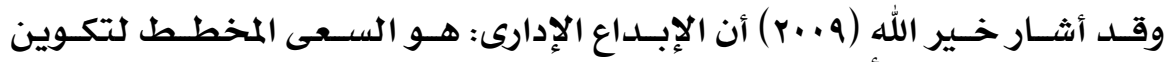

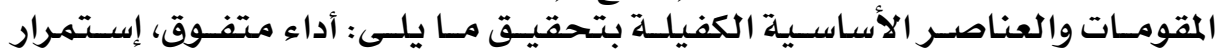

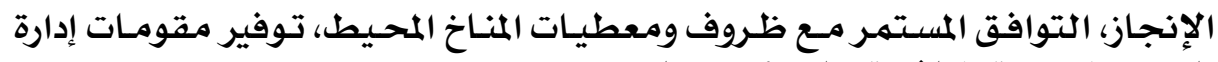

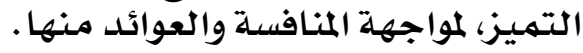

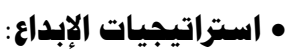

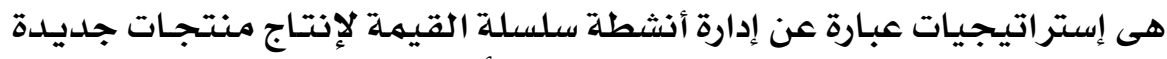

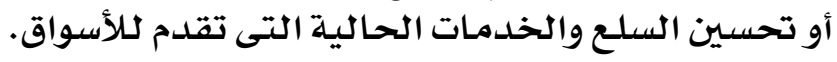

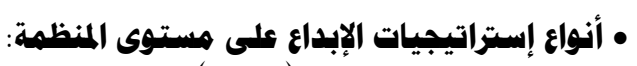

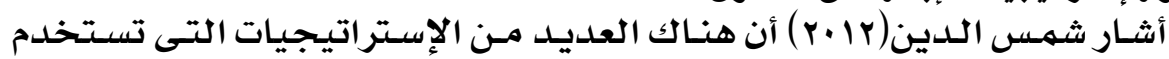

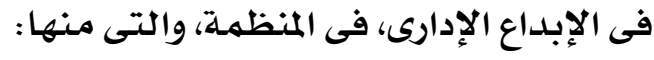

\section{pq}




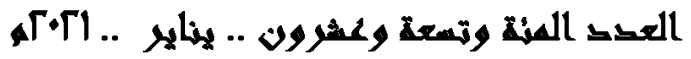

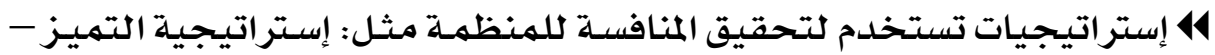

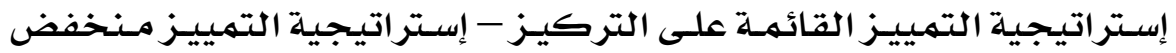

التكلفة.

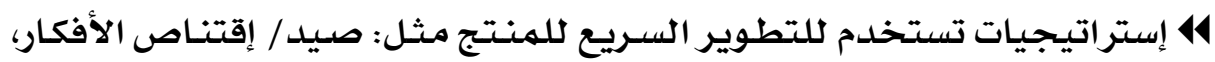

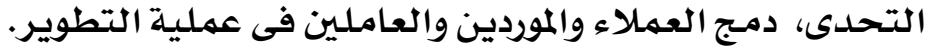

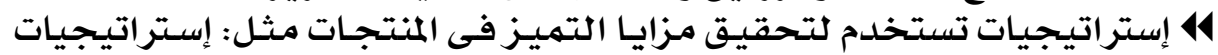

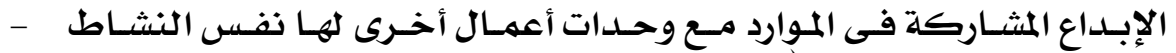

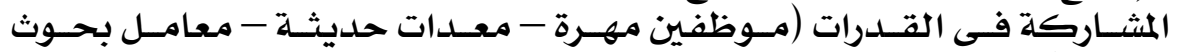

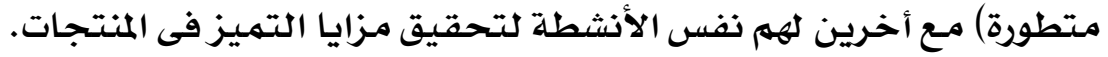

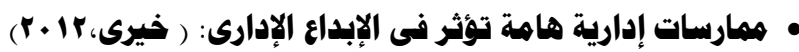

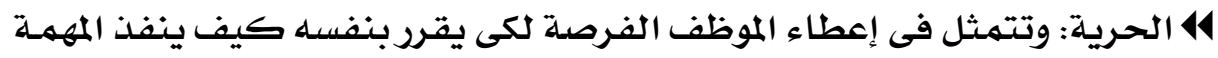
المسدة إليه

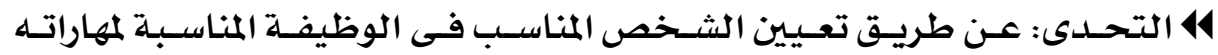

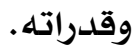

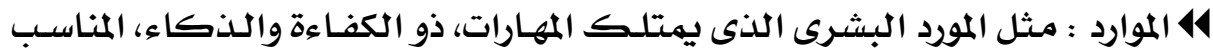

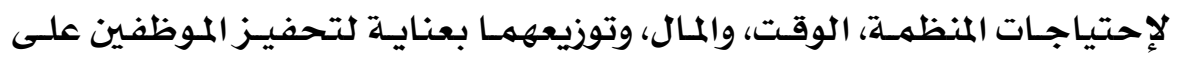

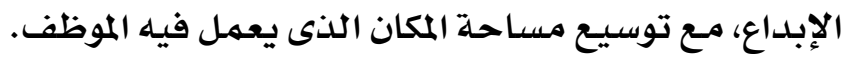

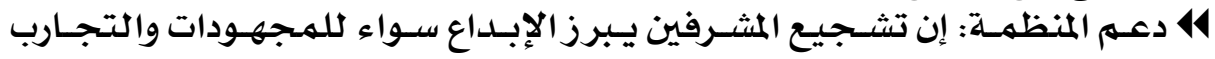

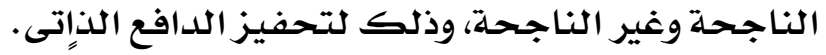

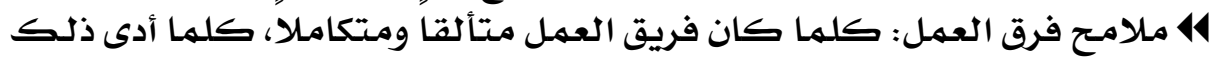

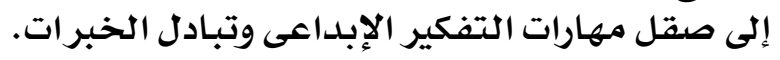

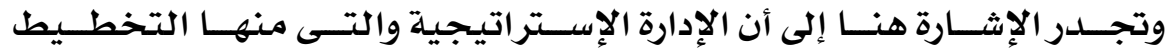

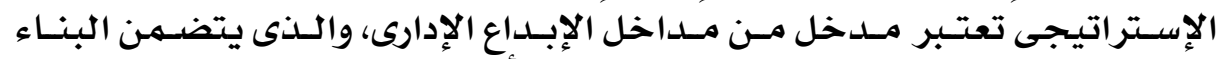

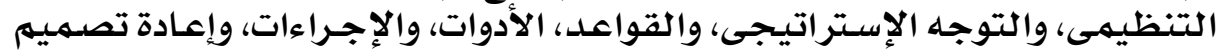

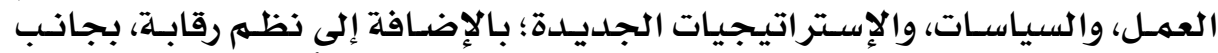

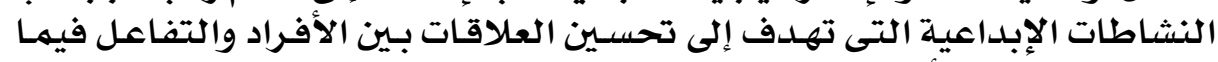

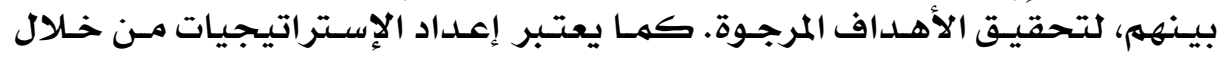

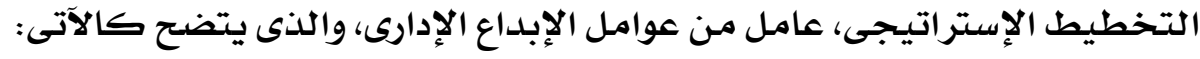

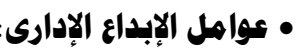

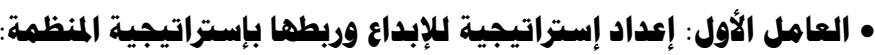

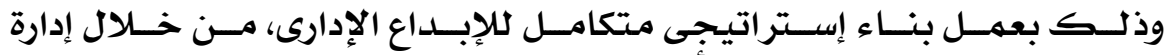

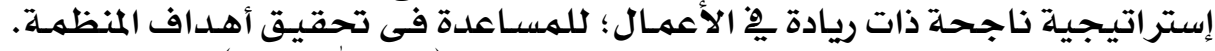

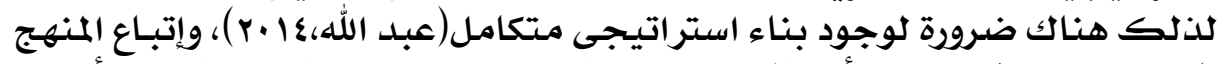

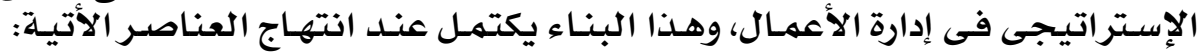

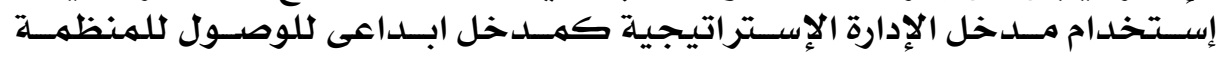

\section{$\varepsilon$}




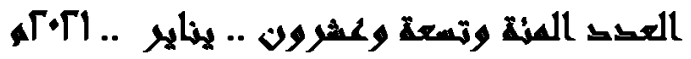

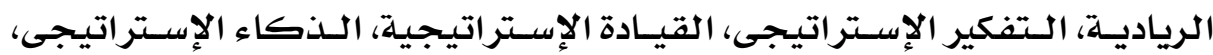

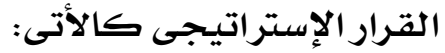

• إستخدام هدخل الإدارة الإستراتيجية كمدخل ابداعى للإوصول للامنظمة الريادية:

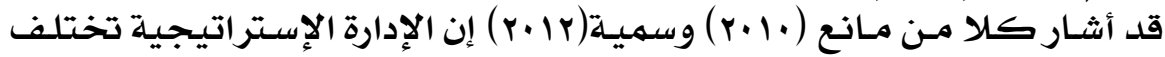

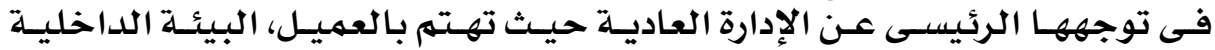

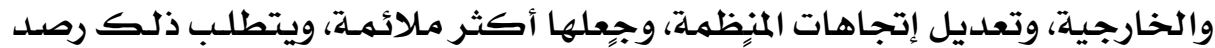

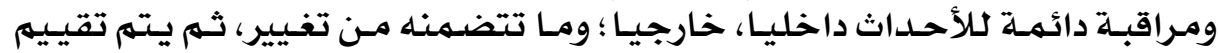

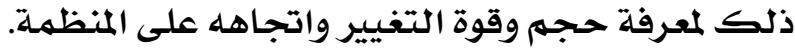

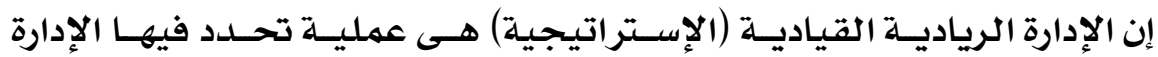

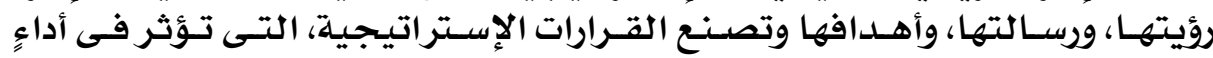

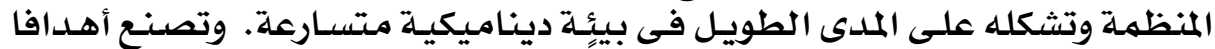

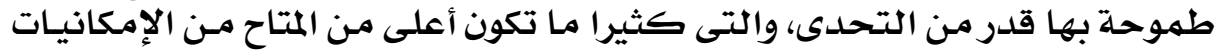

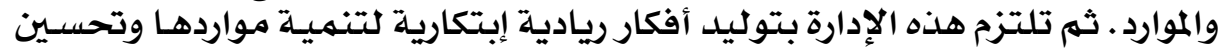

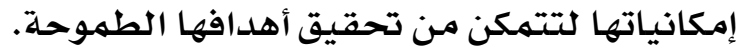

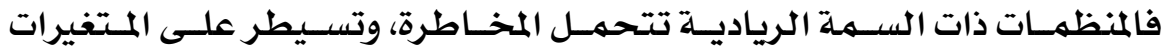

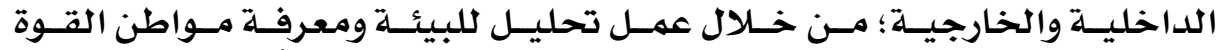

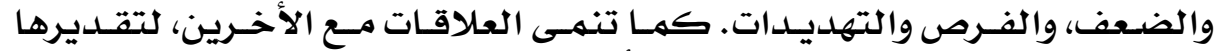

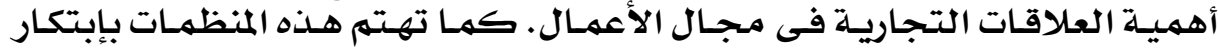

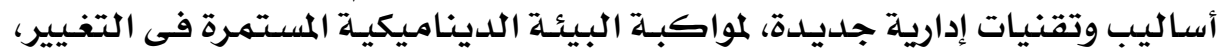

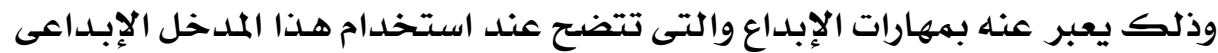
فى المنظمات.

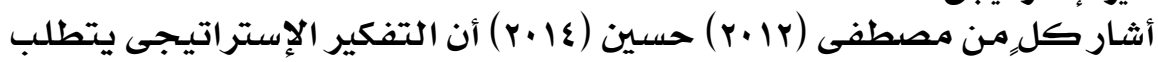

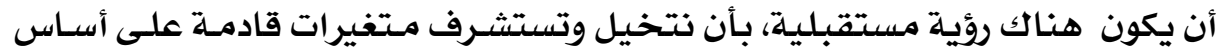

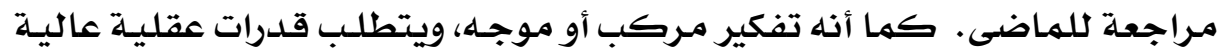

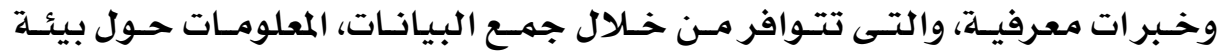

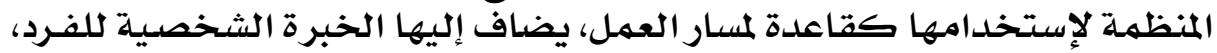

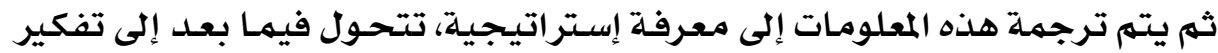

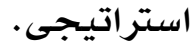

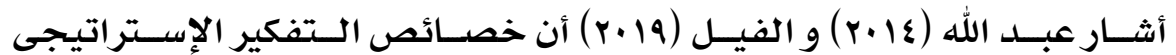

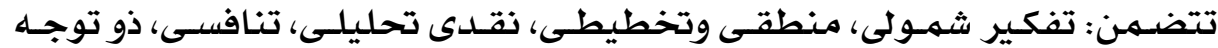

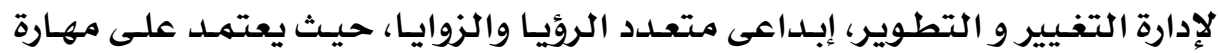

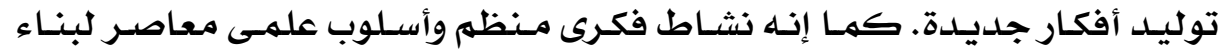

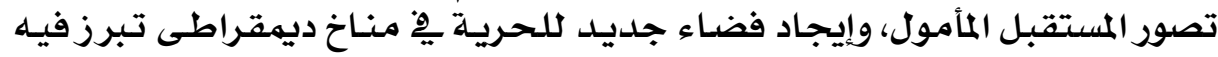

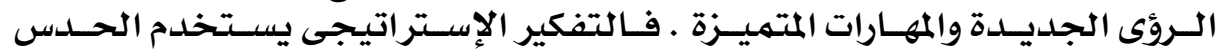

\section{$\varepsilon 1$}




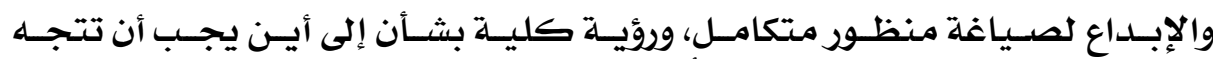

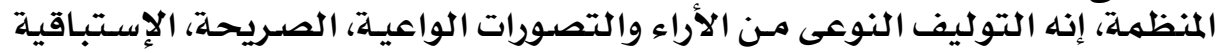

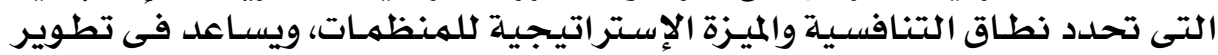

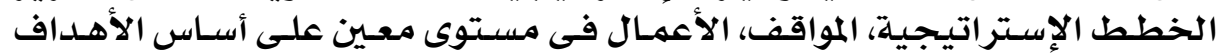

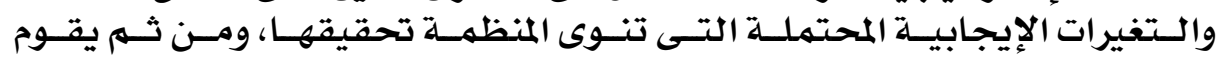
التخطيط بوضـع الإجراءاتات.

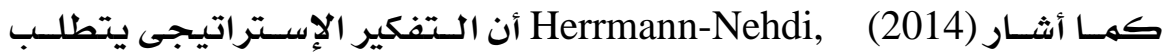

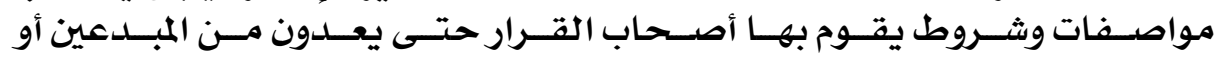

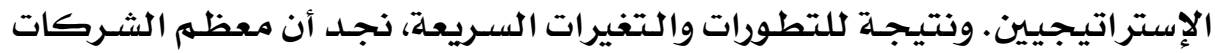

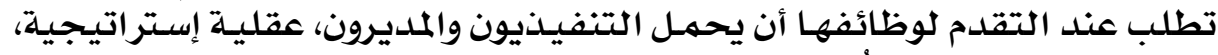

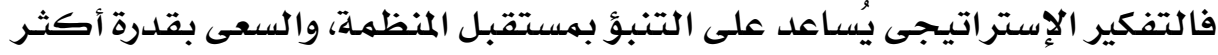

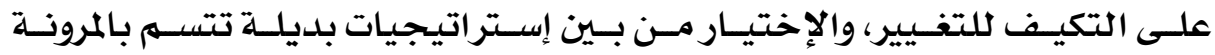

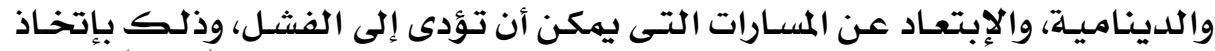

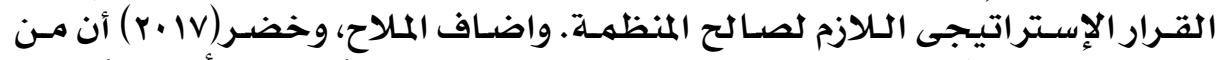

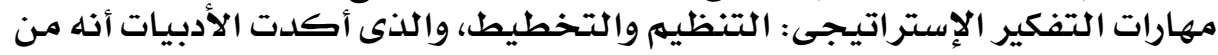

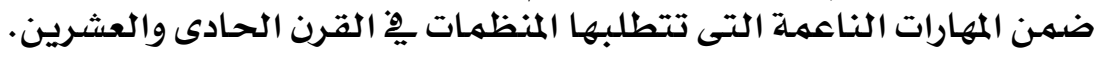

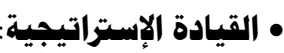

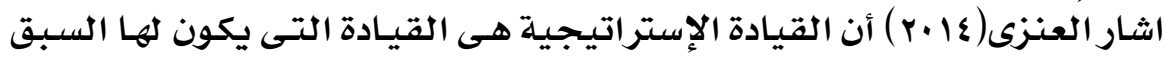

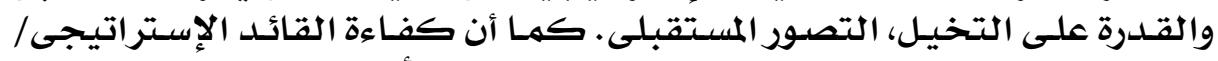

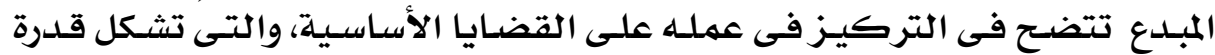

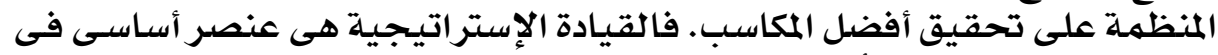

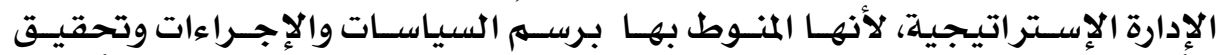

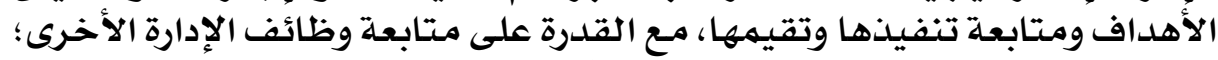

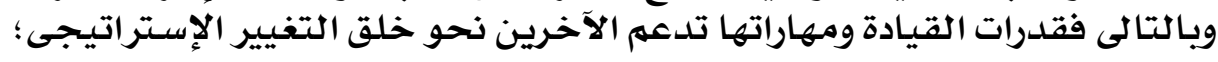

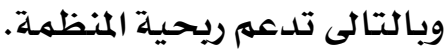

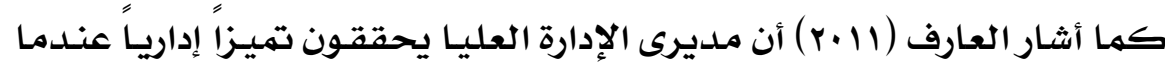

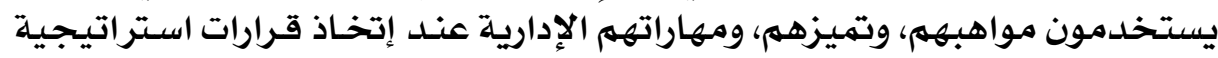

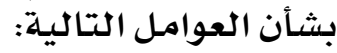

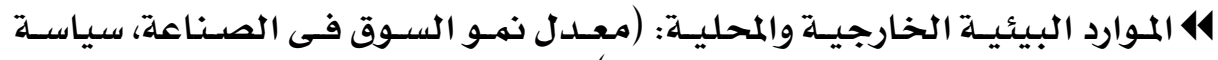

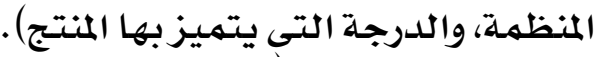

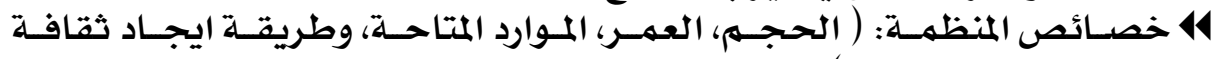
التخطيط في المنظمهة).

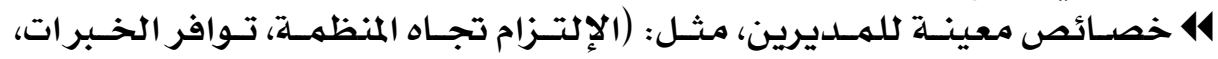

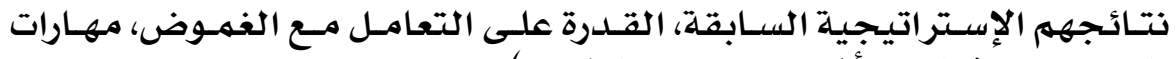

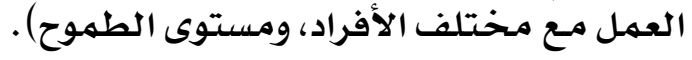

\section{$\varepsilon Y$}




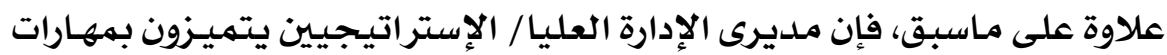

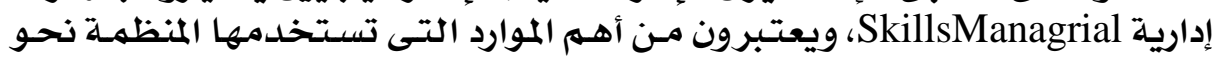

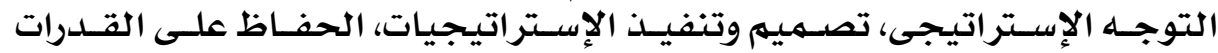

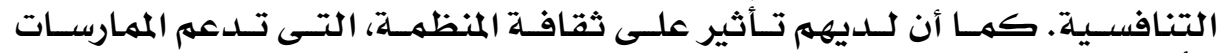

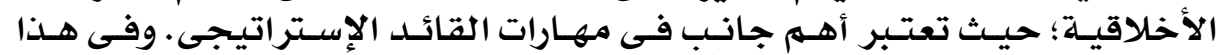

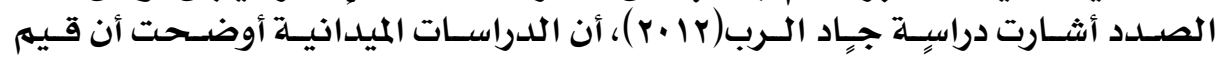

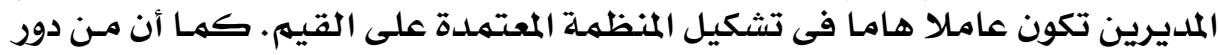

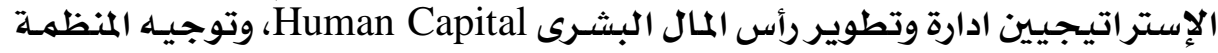

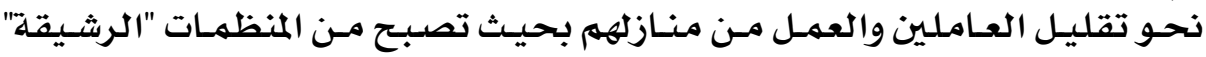

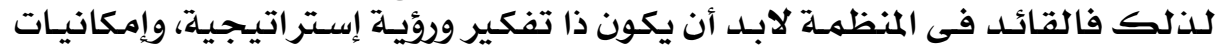
مهاريـة عالية.

\section{• القرار الإستراتيجى:}

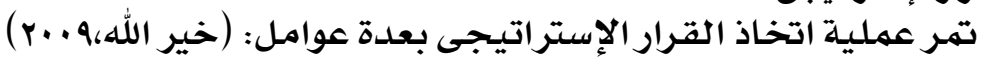

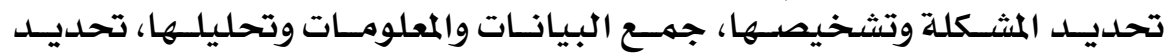

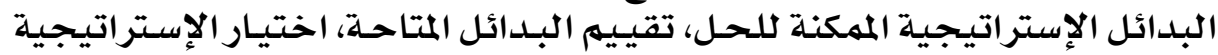

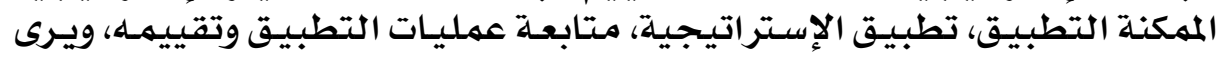

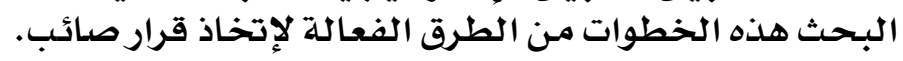

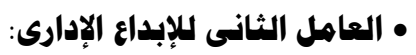

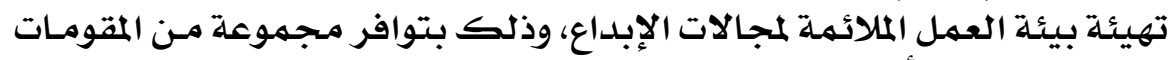
وسيتم عرضيئها بئة كالأتى:

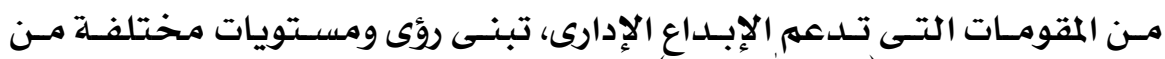

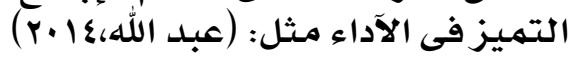

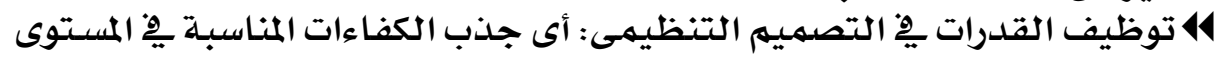

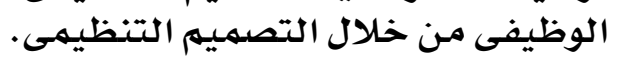

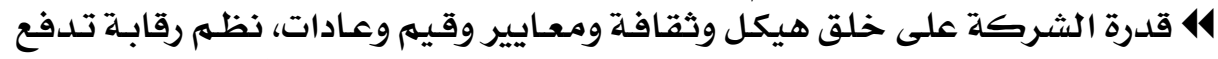

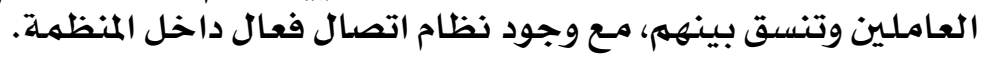

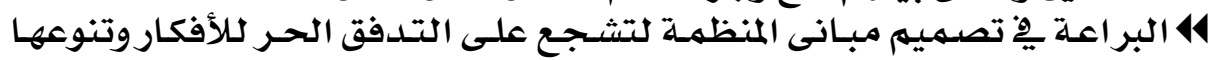

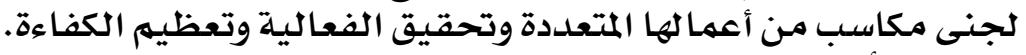

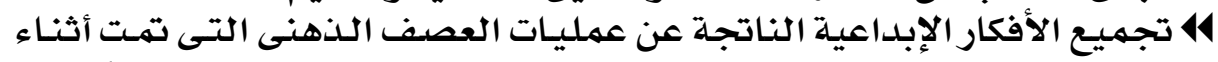

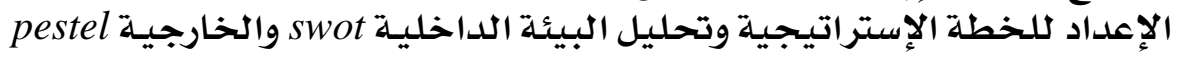

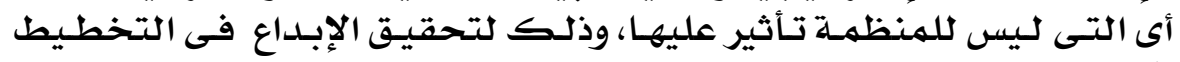

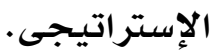

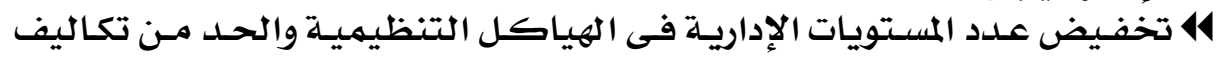
التشغيل.

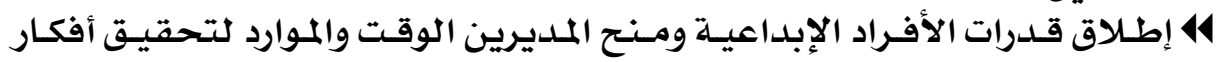

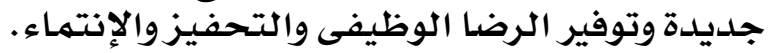

\section{$\varepsilon r$}




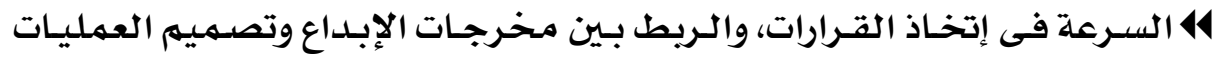

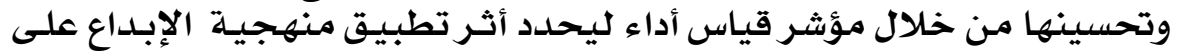
أداء المؤسسـة. آحسئ.

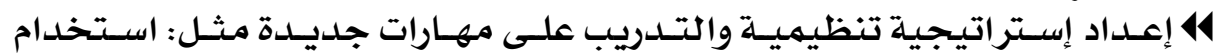

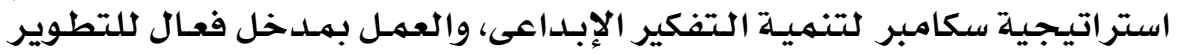

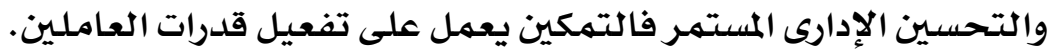

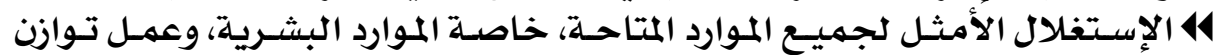

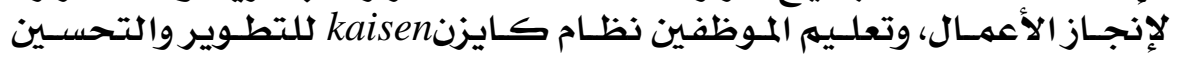

وبذ لك يظهر دور التخطـيط الإسـتراتيـى وتأثيره في ريـادة الأعهـال، الجـودة

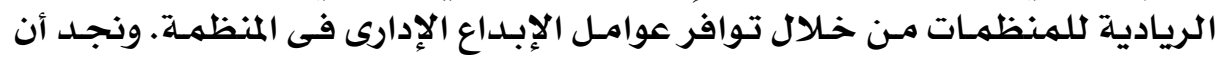

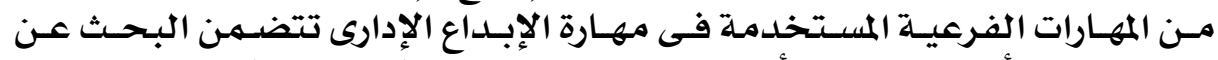

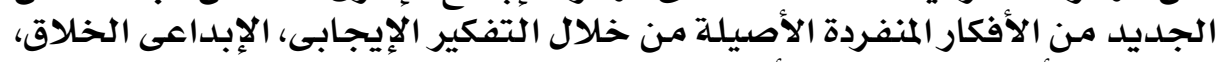

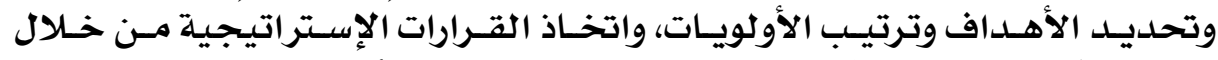

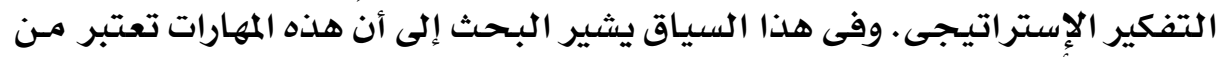

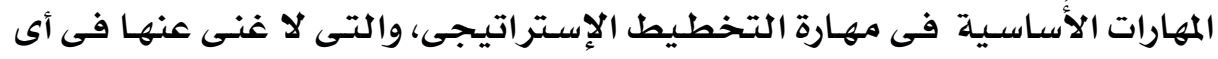

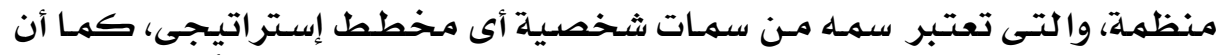

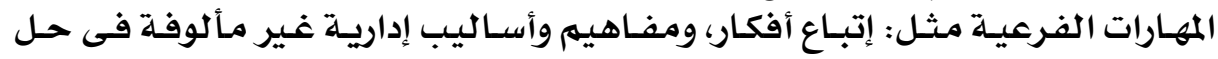

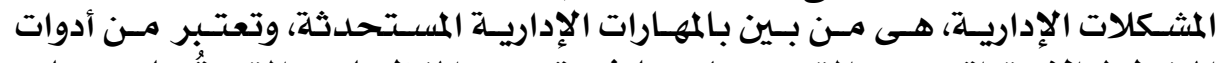

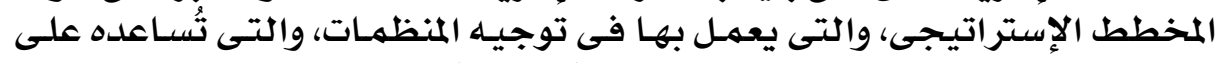

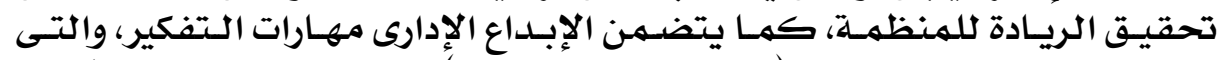

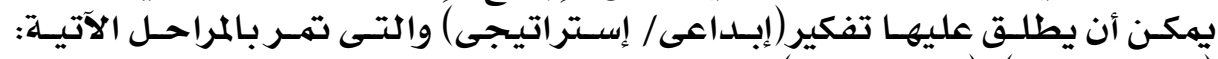

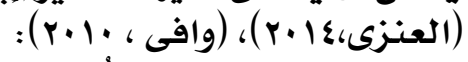

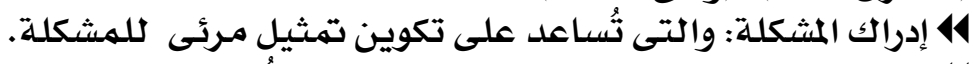

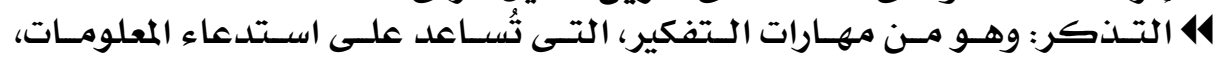

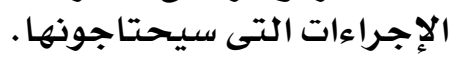

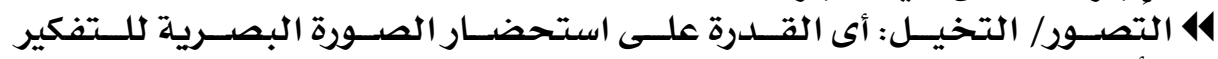

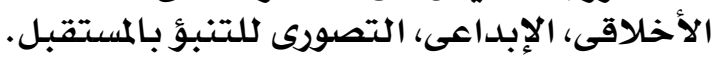

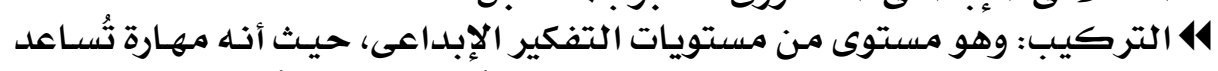

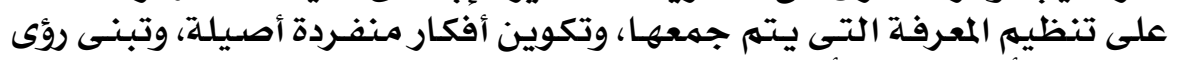

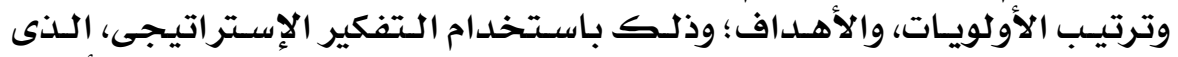

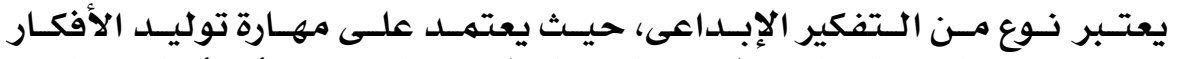

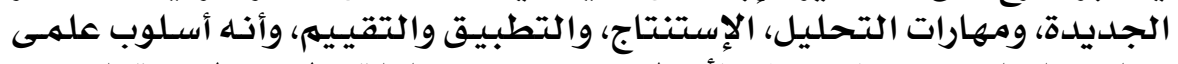

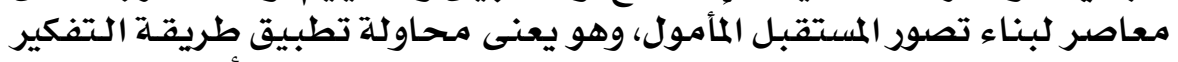

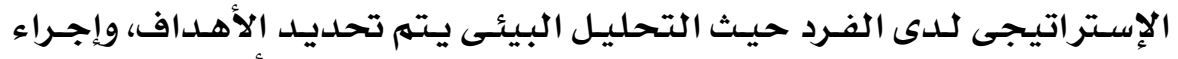

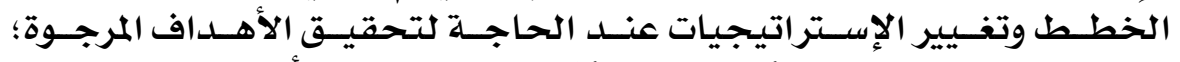

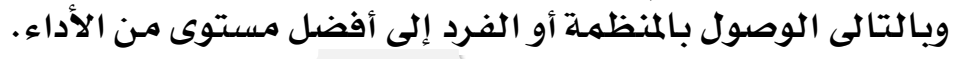

\section{$\varepsilon \varepsilon$}




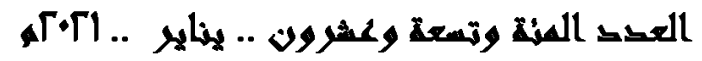

41 التقييم للقرار الإستراتيجى الذى تم اتخاذه .

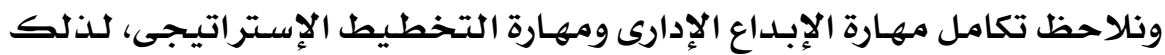

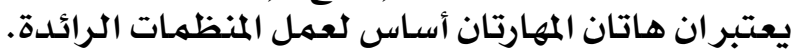

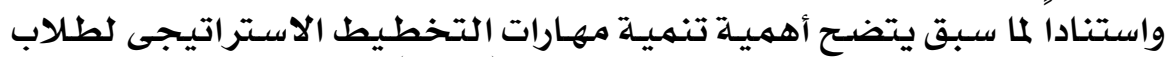

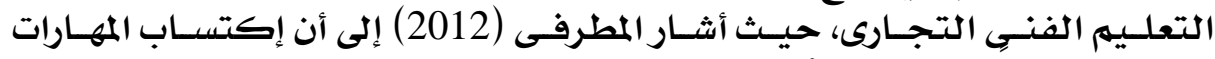

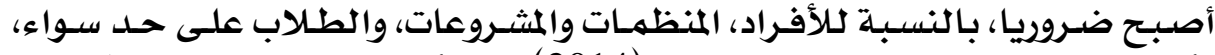

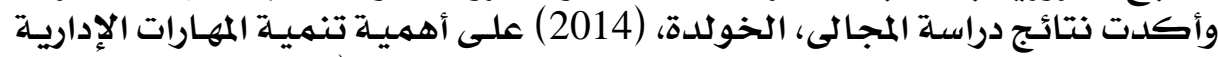

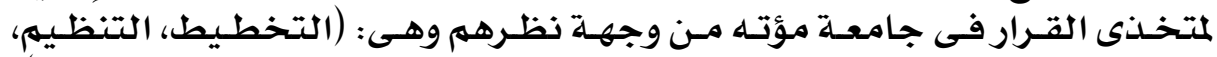

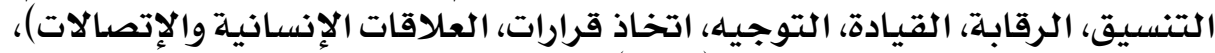

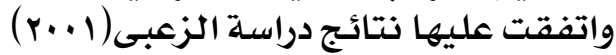

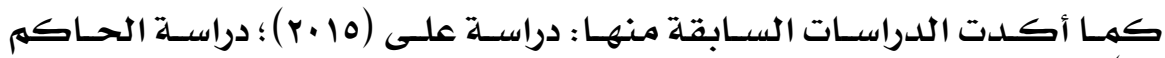

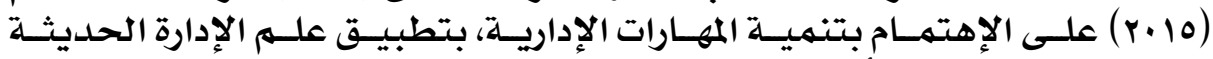

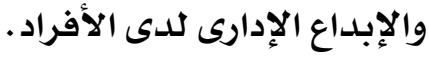

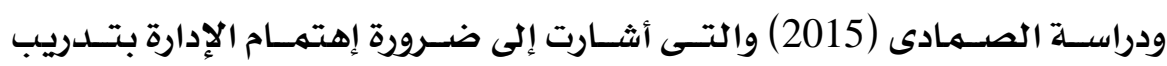

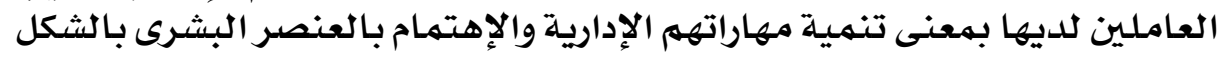

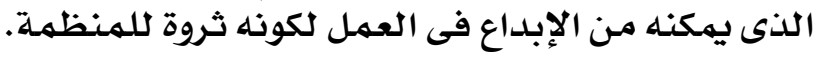

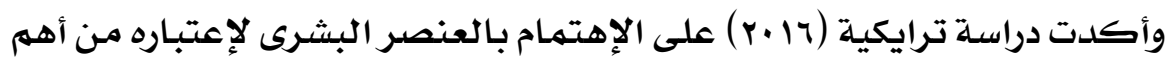

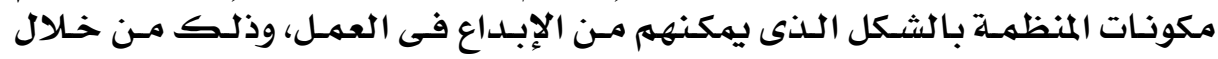
الإهتمام بالتدريب وتنمية المهارات.

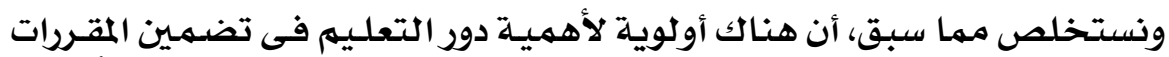

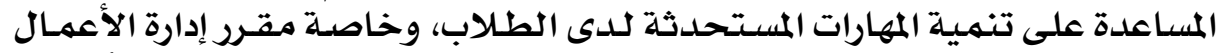

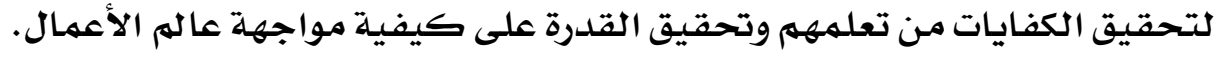

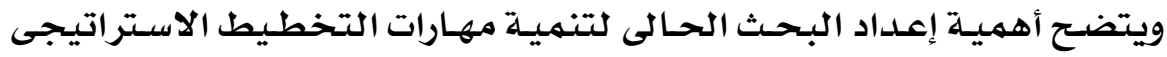

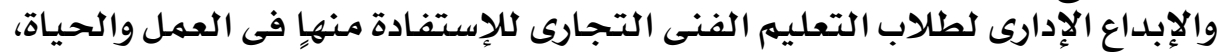

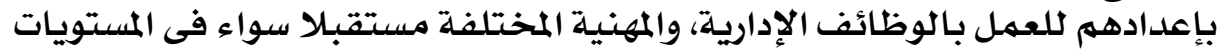

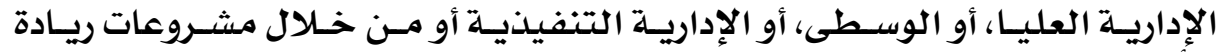

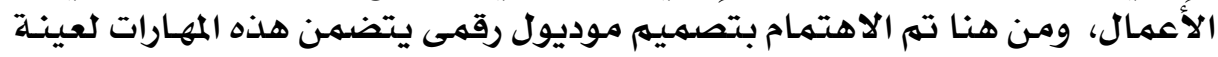

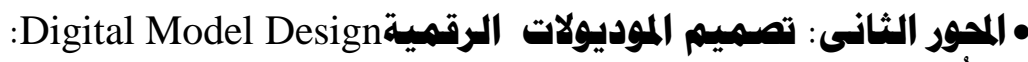

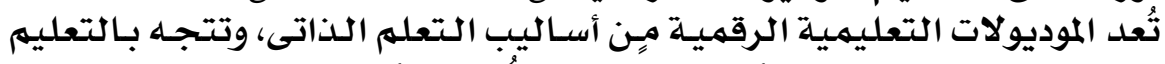

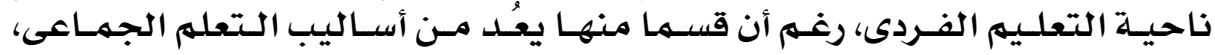

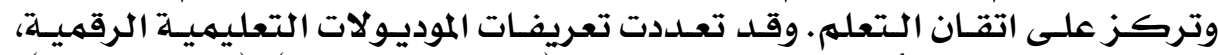

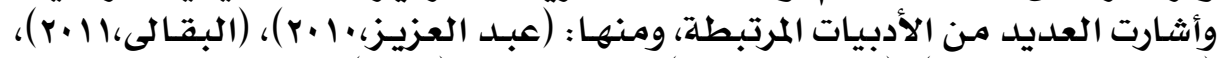

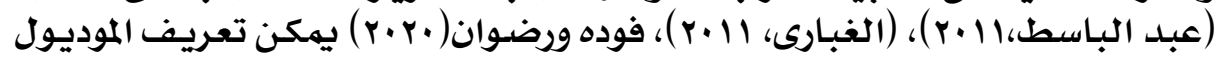

\section{\& 0}




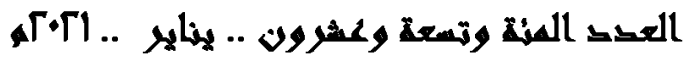

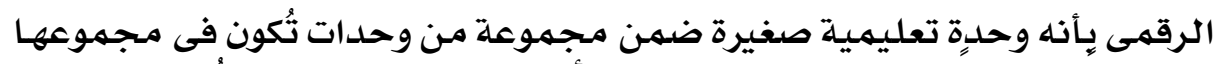

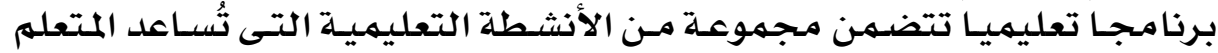

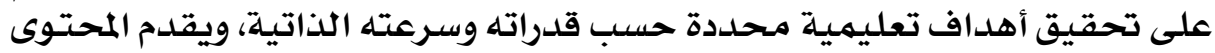

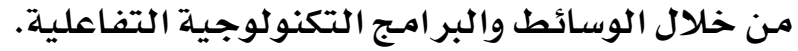

• التصميم التعليمى Instructional Design:

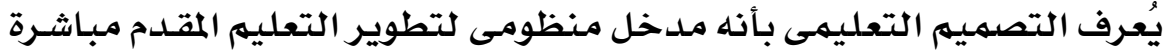

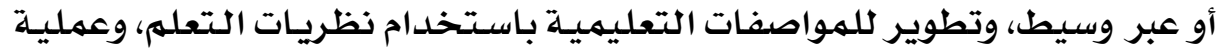

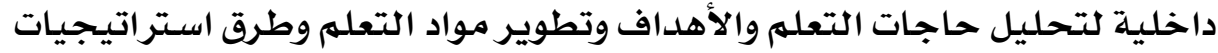

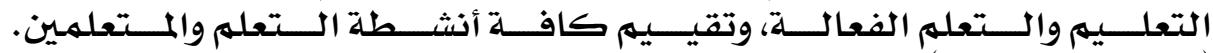

(Simonson,2005)

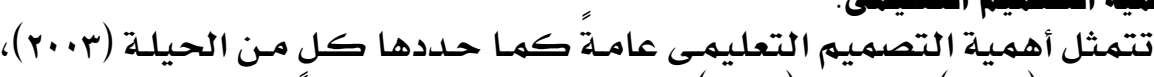

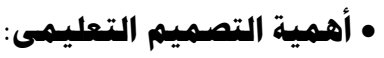

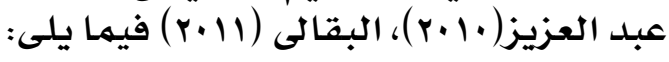

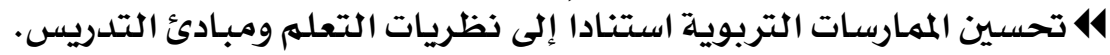

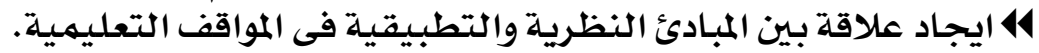

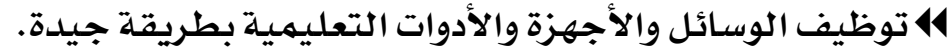

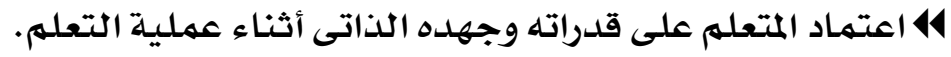

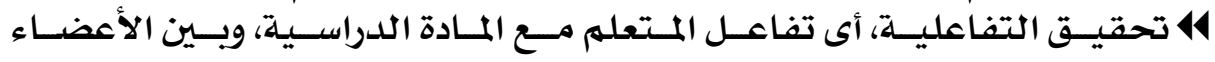

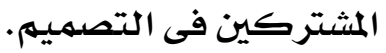
ه تغيير دور المعلمى وجعله التصهيم منظماً للظروف البيئية التى تُسهل حدوث التعلهم. • الأسس التربوية لتصميم الموديولات الرقميمية:

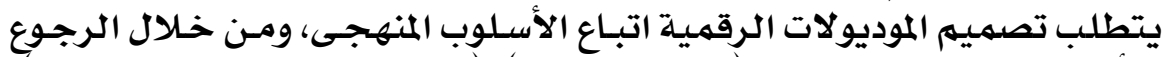

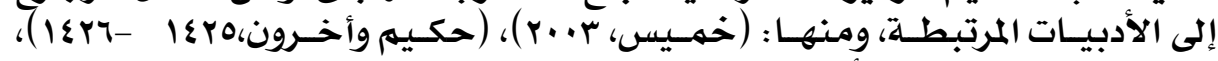
خلصت الباحثتان إلى الأسس التسب التالية:

14 تحديد الأهداف التعليمية المرجو تحقيقها.

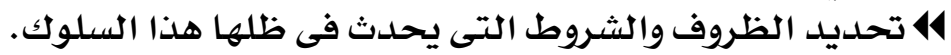

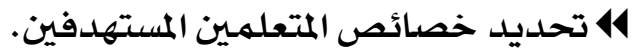

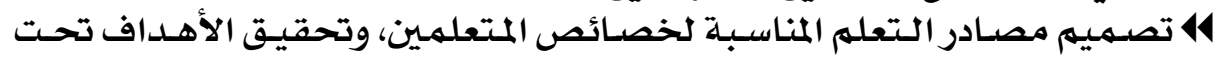
هذه الشروط.

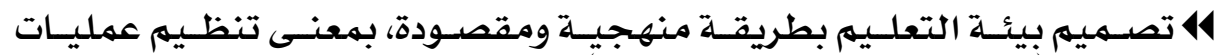

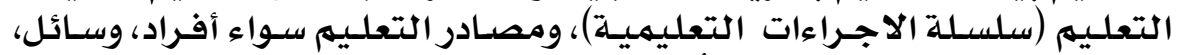

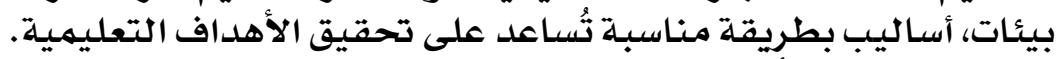

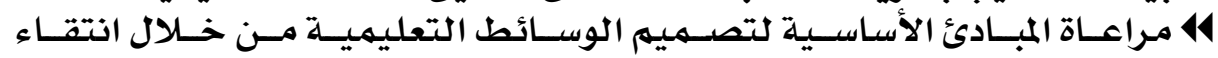

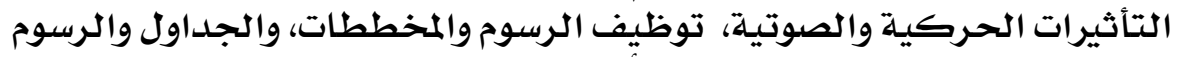

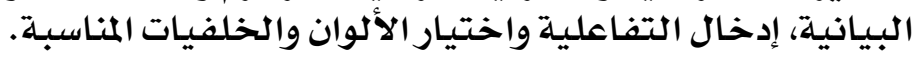




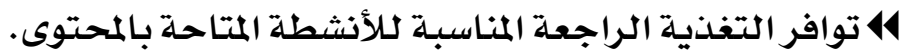

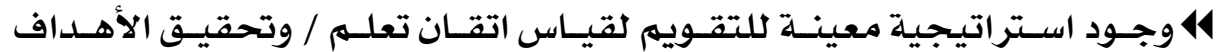

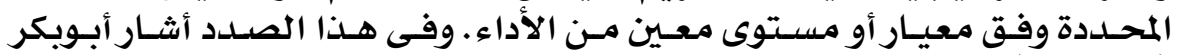

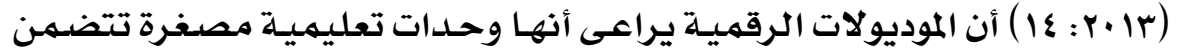

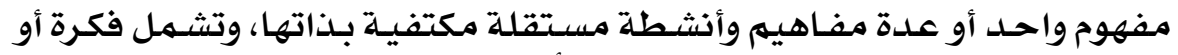

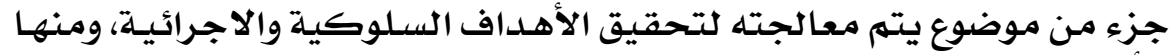
الأهداف العامة موفوع للمنهج الدراسى.

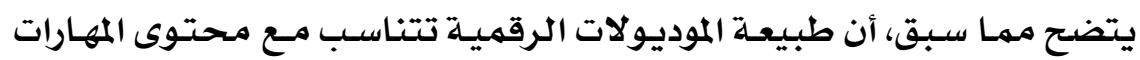

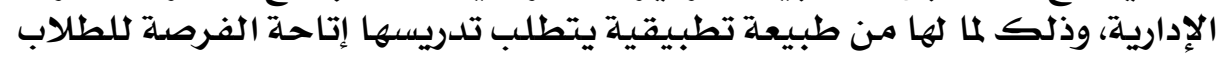

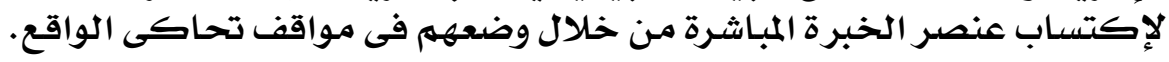

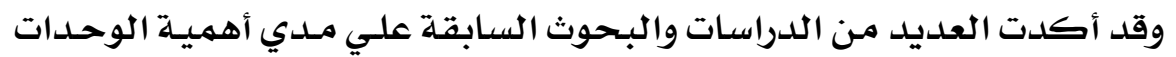

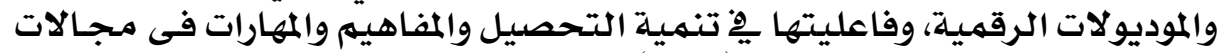

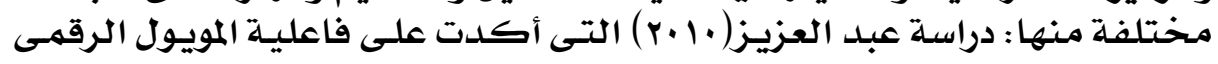

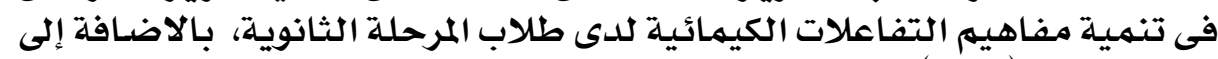

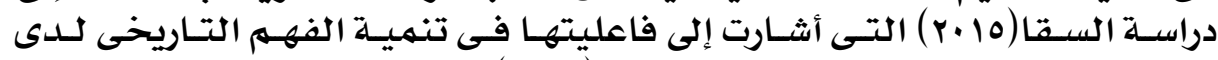

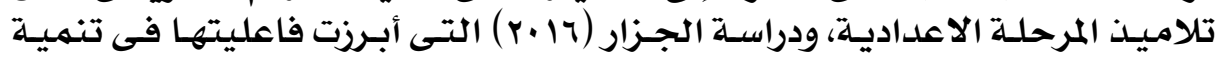

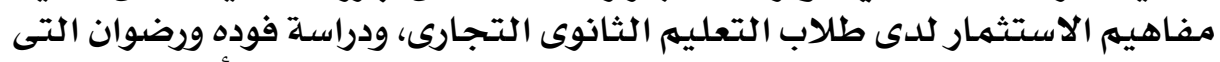

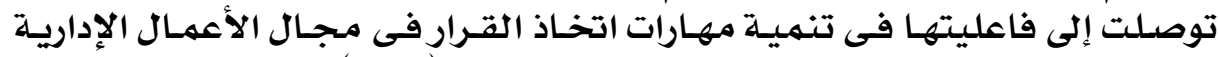

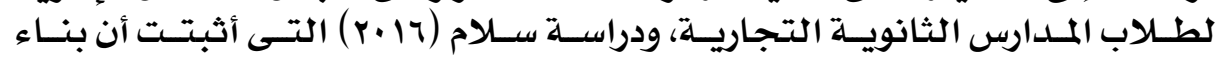

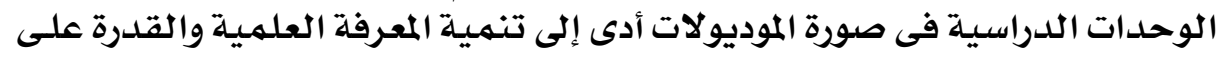

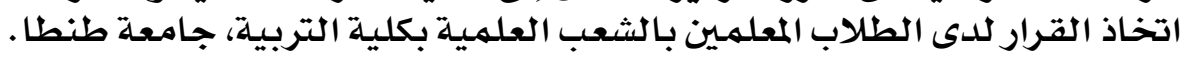

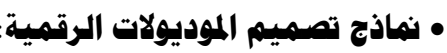

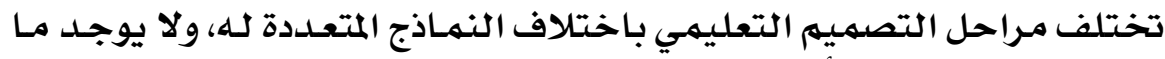

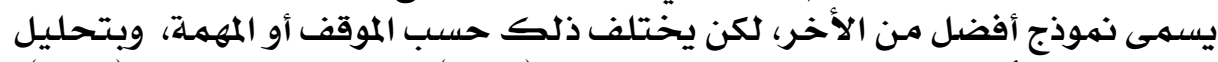

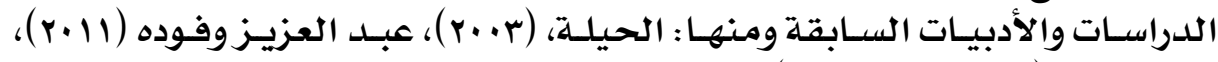

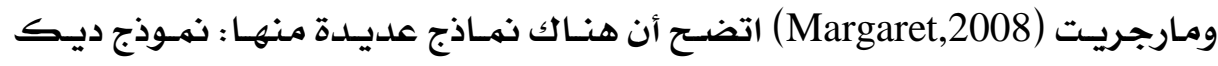

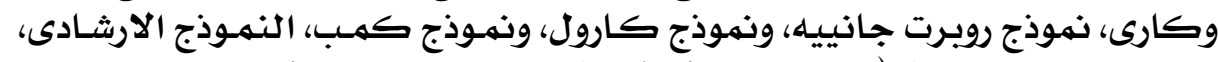

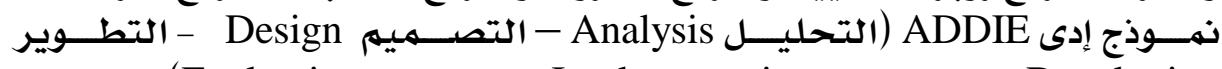
البحت Developing البحث الحالى على نهوذج إدى.

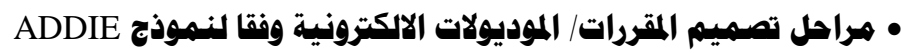

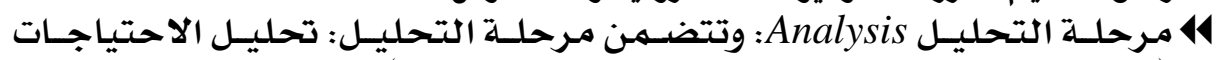

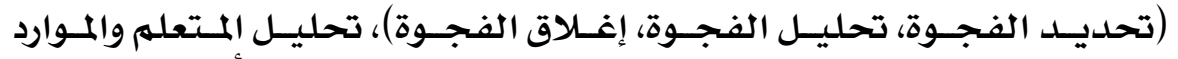

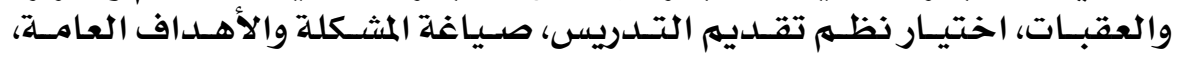
تحليل المحتوى، تحليل التيسار نظميس. تقديم. 


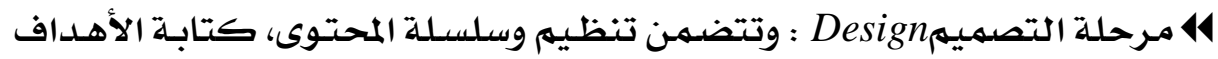

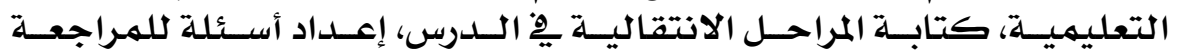

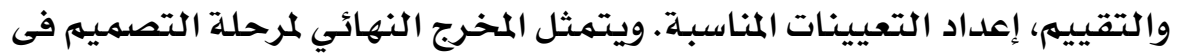
كتابة السيناريوهات الخاصدة بالدروس Storyboards

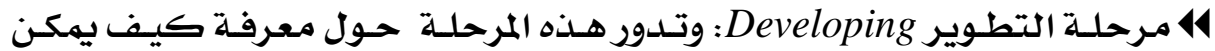

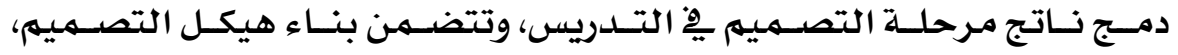

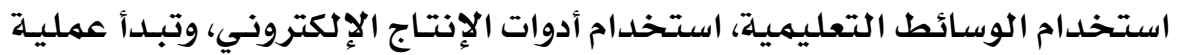

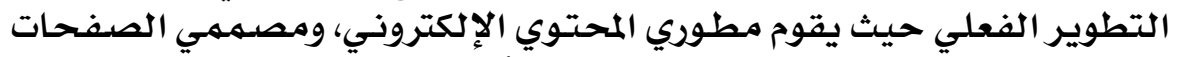

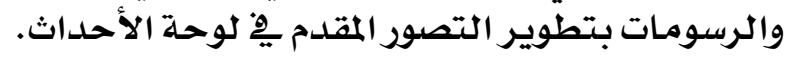

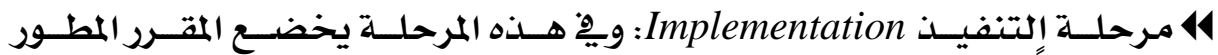

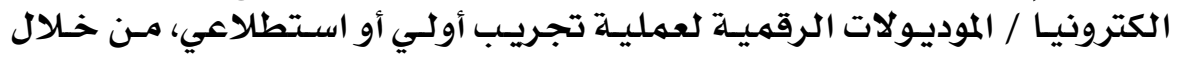

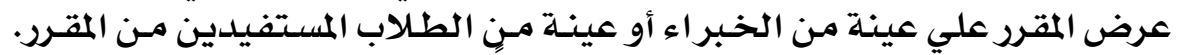

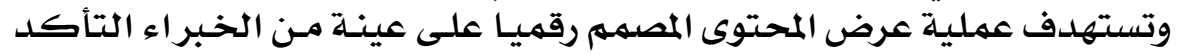

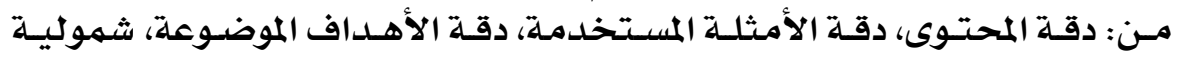

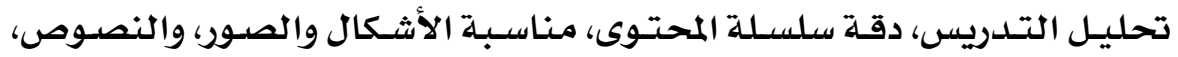

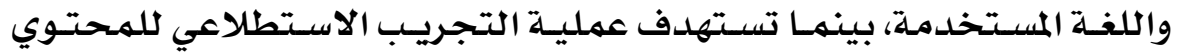

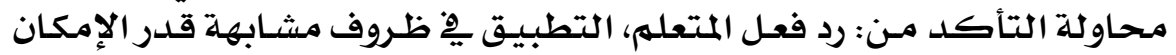
لظروف التطبيق الفعلية.

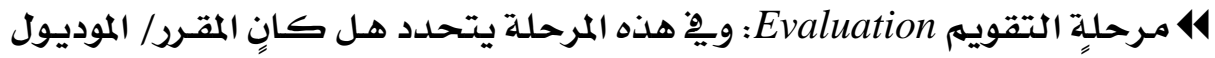

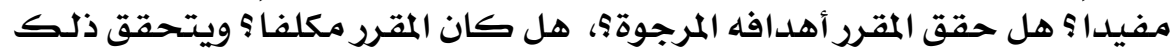

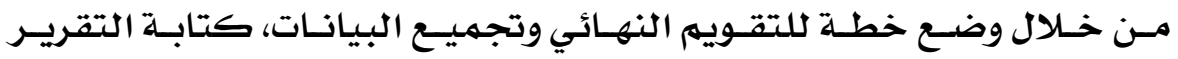

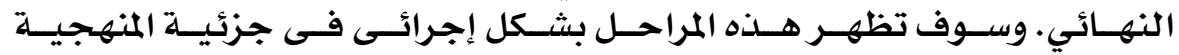
والاجراءات.

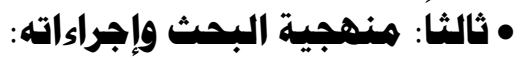

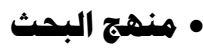 \\ اتبـع الباحثتان فى هذا البحث كلٍ من :

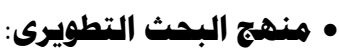

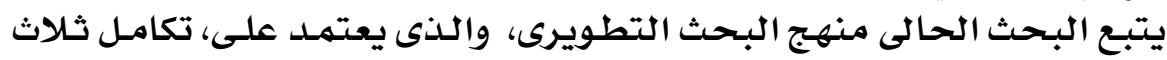

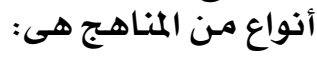

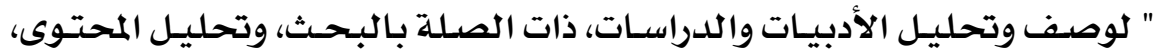

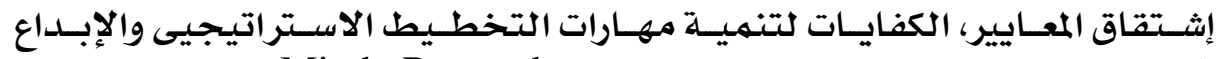

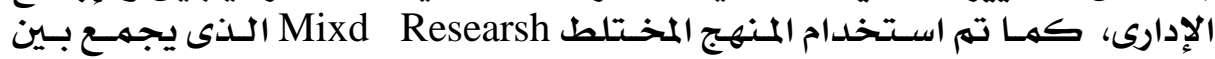

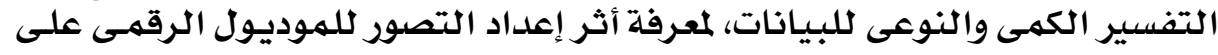

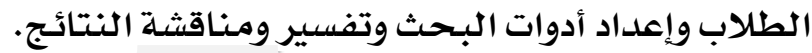

\section{$\varepsilon \wedge$}




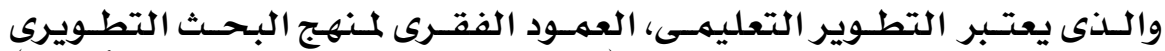

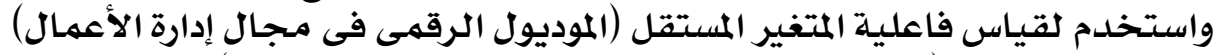

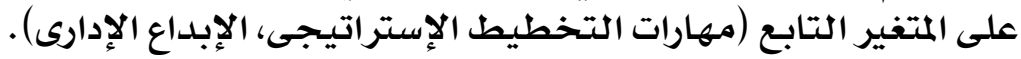

• منهمج تطوير المنظومات،

وذلك بتطبيق نهاذج التطوير (التصهميهم التعليهى) ومـا تتضهمنهـ مـن التقـويهم

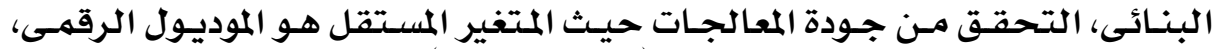

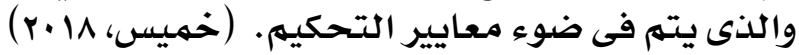

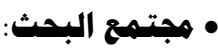

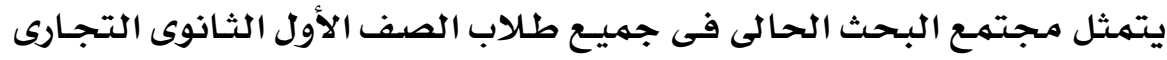

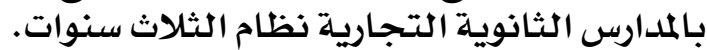

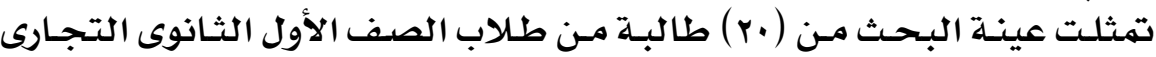

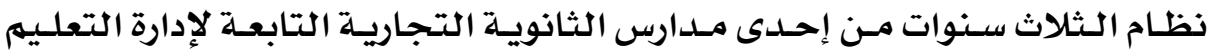

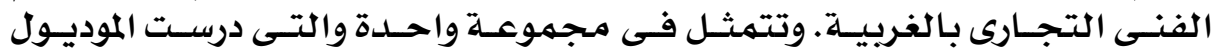

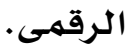

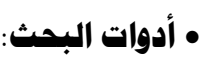
اشتمهل البـحث على الأدوات الآتية:

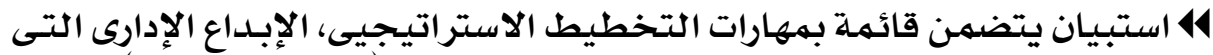

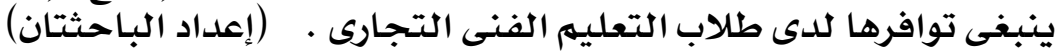

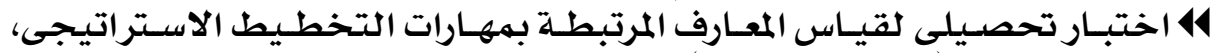

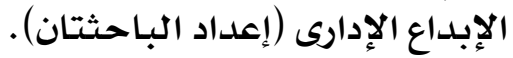

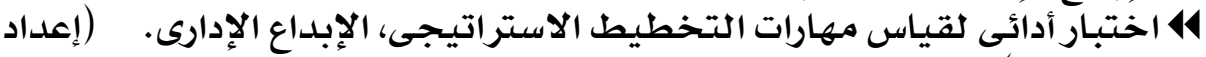
الباحثتان) • إجراءات الدراسة التحليلية، وإعداد أدوات البحث: ا - إجراءات إعداد قائمة المهارات فى شكل استببيان:

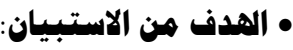

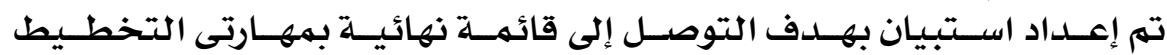

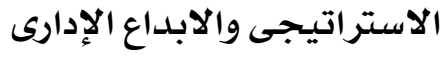

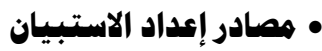

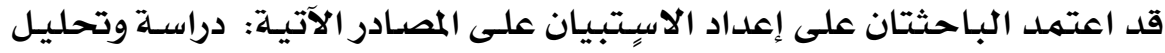

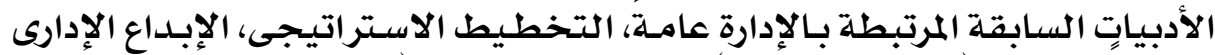

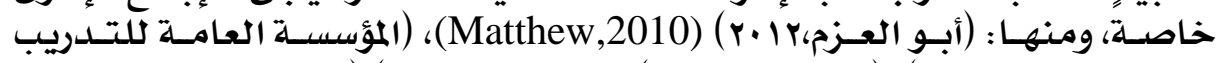

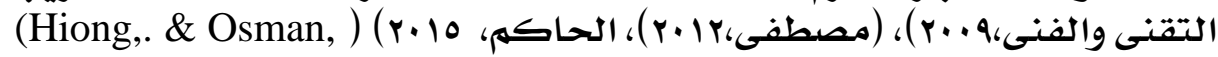

\section{$\varepsilon 9$}




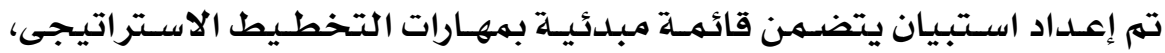

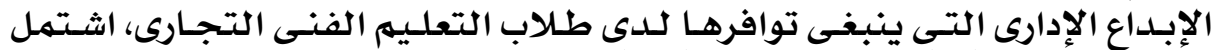

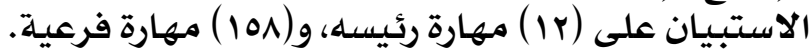

• مدرق الاستبيان:

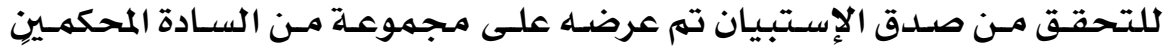

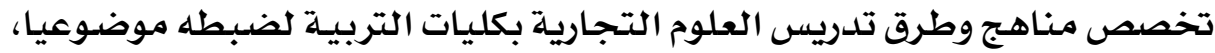

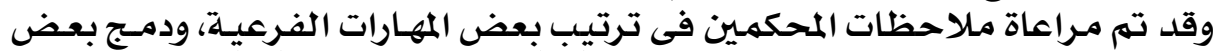

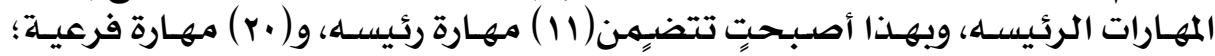

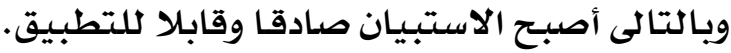

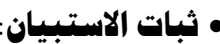

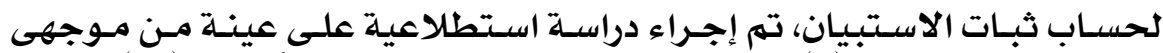

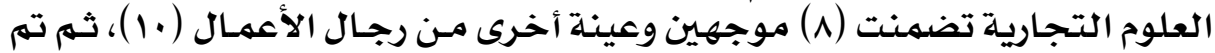

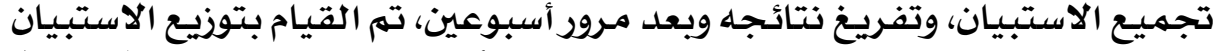

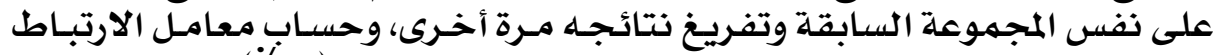

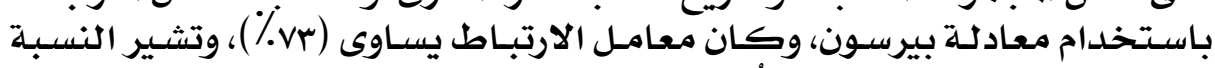

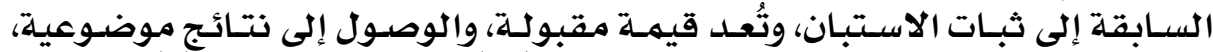

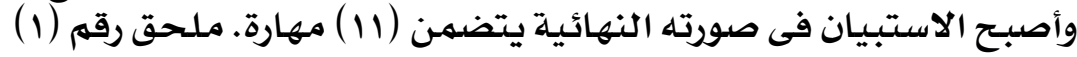

r-اجراءات تصسيم الموديول الرقمي:

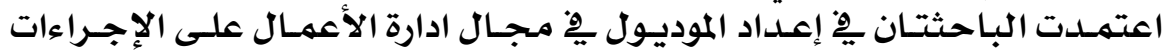

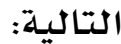

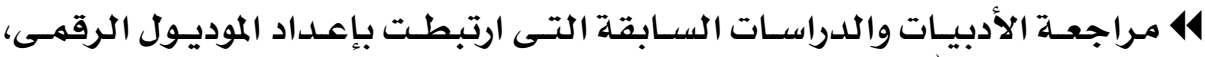

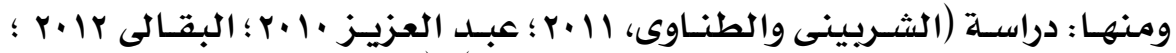

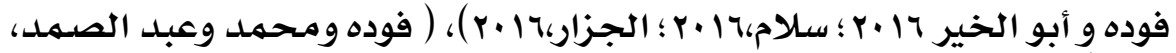

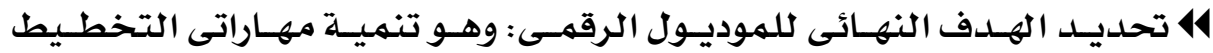

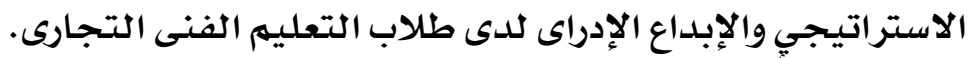

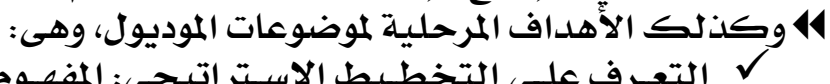

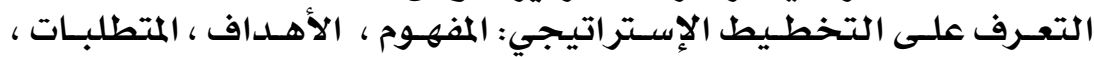
المراحل.

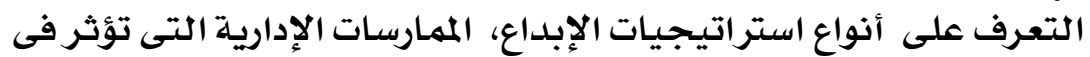

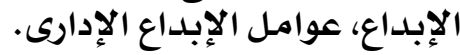

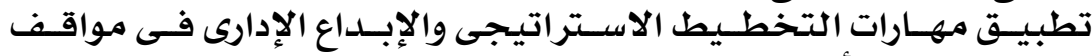

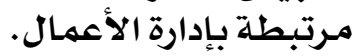

تم تصهيهم الموديول الرقهي المقترح وفق خطـوات مـراحل نهوذج إدى (ADDIE) كها يلى :ته

\section{$\boldsymbol{\theta}$}




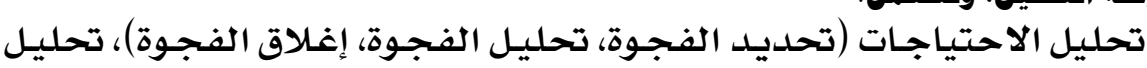

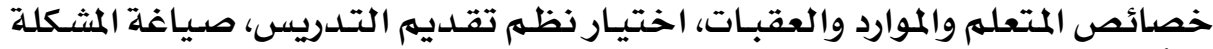

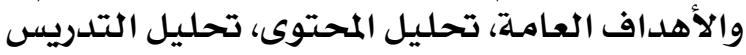

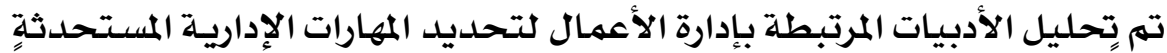

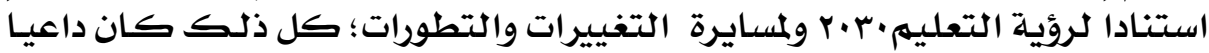

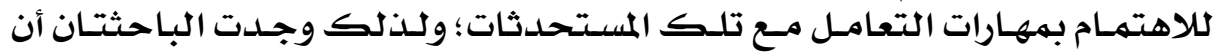

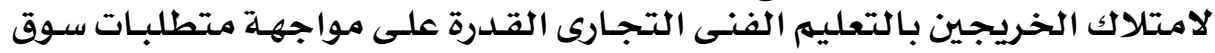

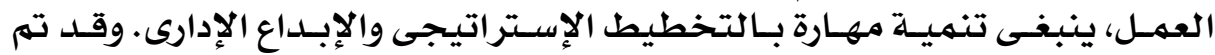

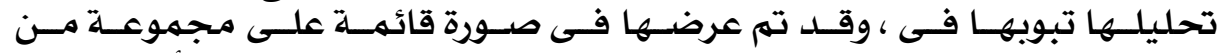

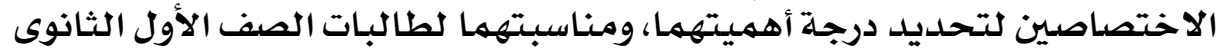

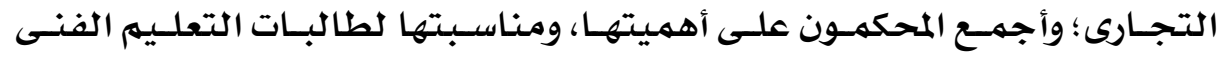

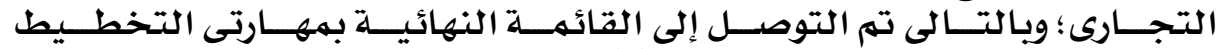

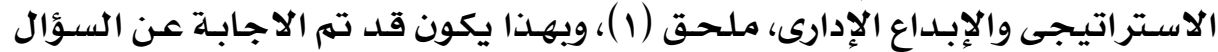

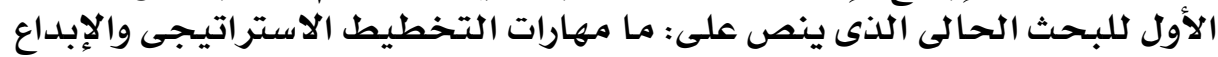

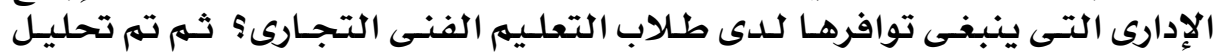

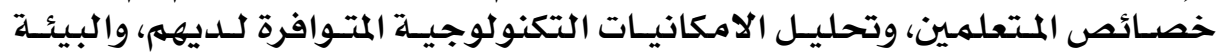

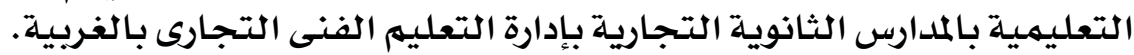

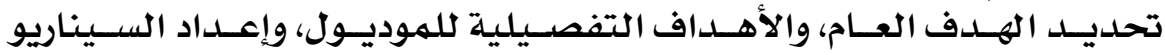

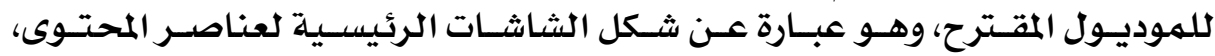

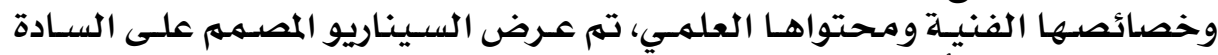

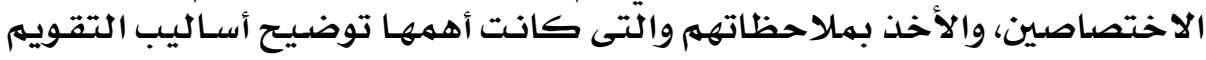

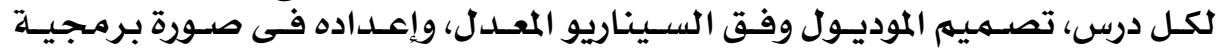

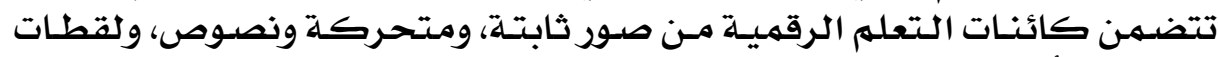

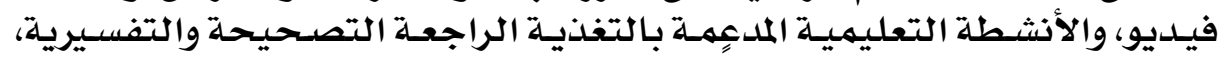

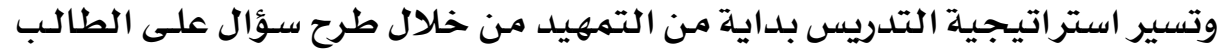

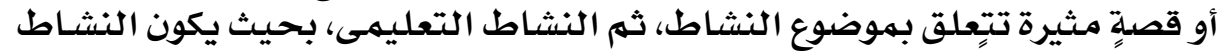

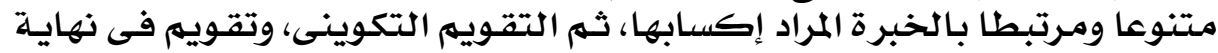

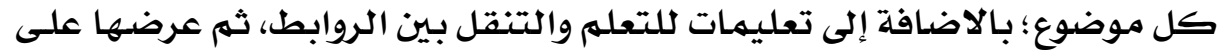

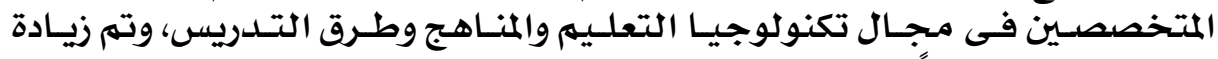

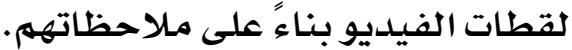

• هرحلة التطوير:

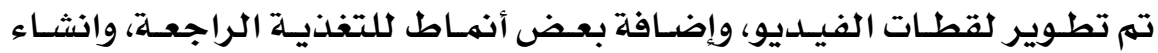

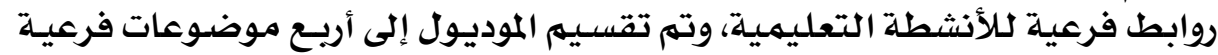

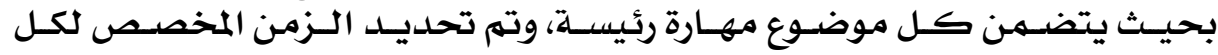




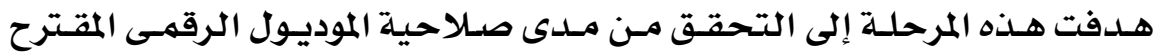

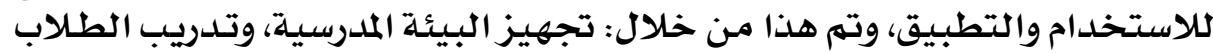

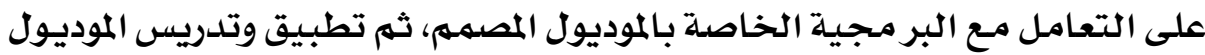

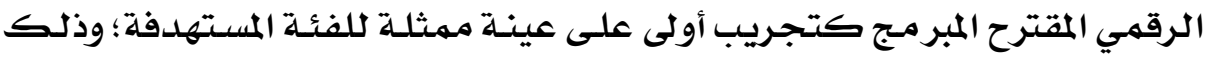

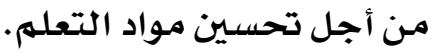

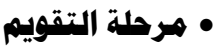

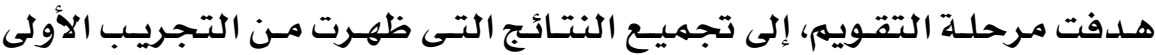

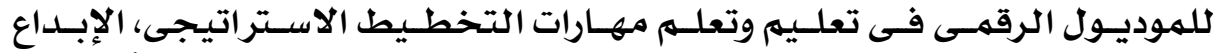

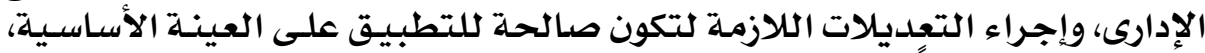

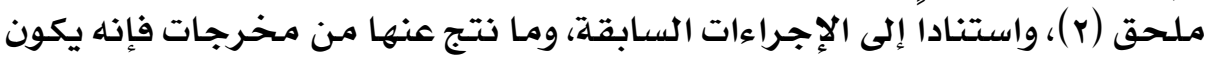

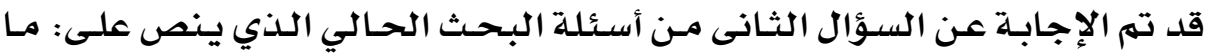

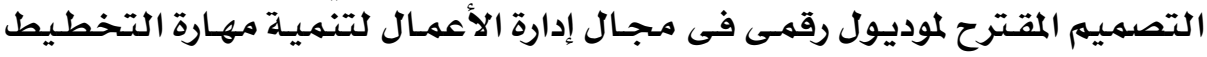

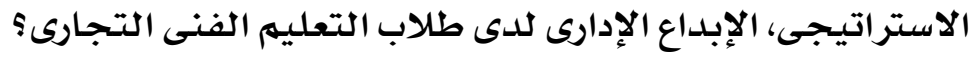

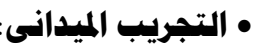

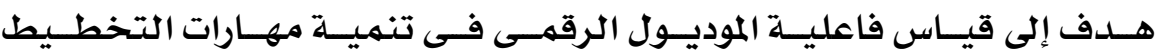

الاستراتيجىى، الإبلداع الإدارى ولتحقيق هذا الهدف تم تنفيذ الخطوات التاليـة:

ه تطبيق أدوات القياس (اختبـار المِعارف، اختبـار المهارات) تطبيقاً قبليـاً على عينـة

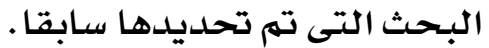

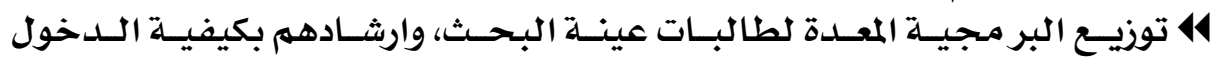

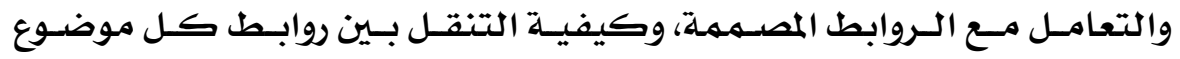

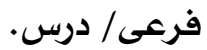

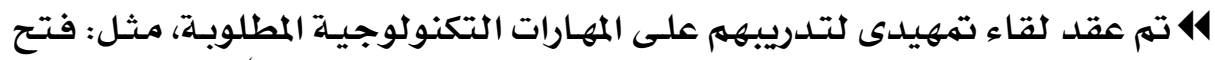

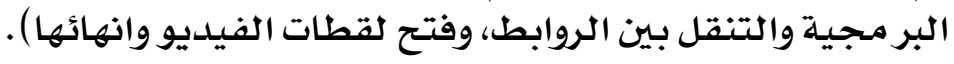

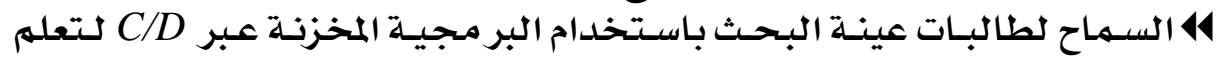

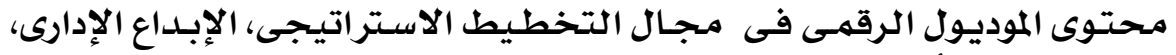

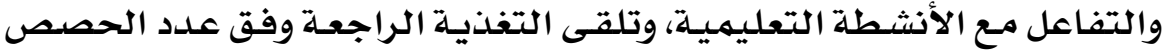
المحلدد.

ه تطبيق أدوات القياس تطبيقاً بعدياً على عينـة البـحث.

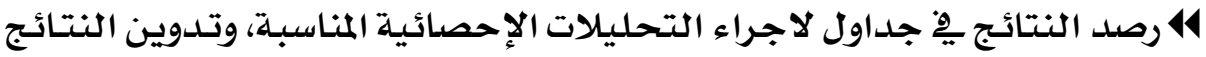

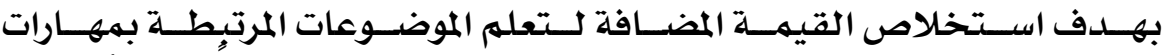

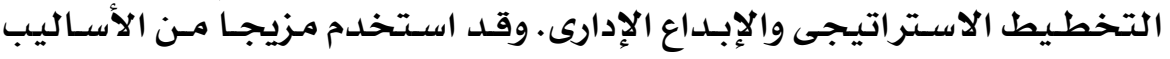

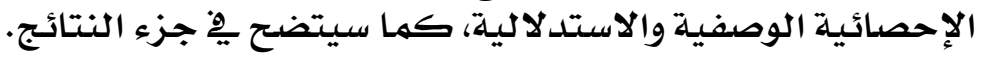

\section{$\bullet Y$}




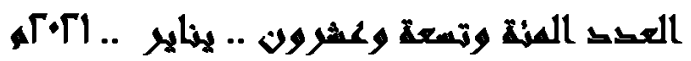

• أدوات القياس:

ا - إعداد اختبار المعارف المرتبطة بمهارات التخطيط الاستراتيجى، الإبداع الإدارى.

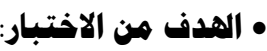

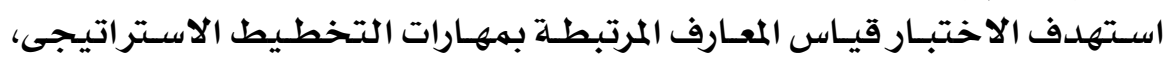

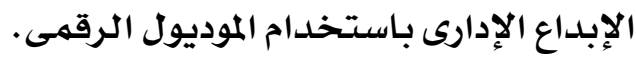

• وصف الاختبار:

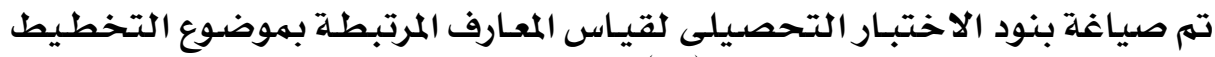

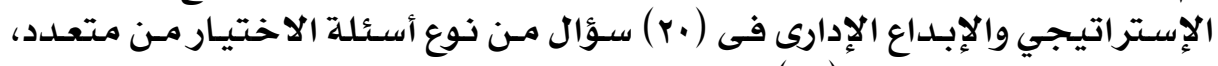

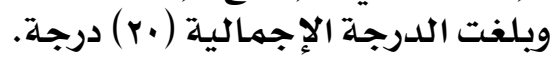

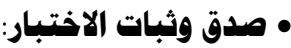

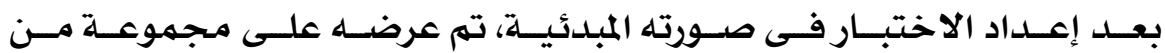

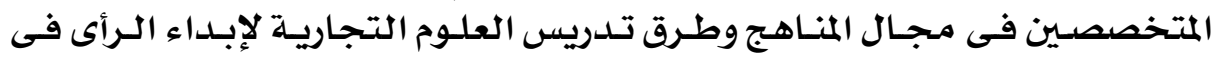

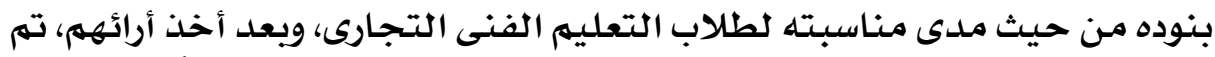

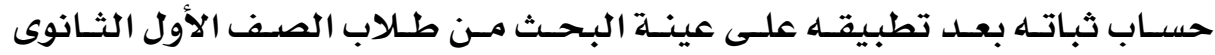

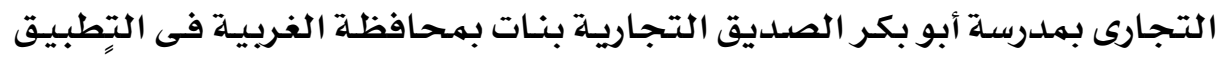

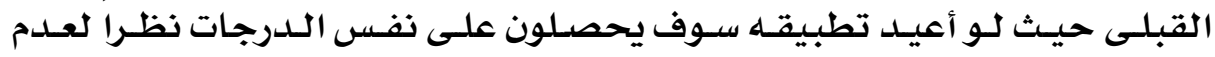

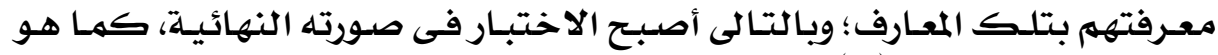

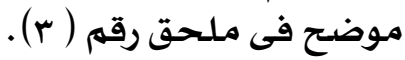
r- إعداد الاختبار الأدائى للاهمهارات: • الهدف هن الاختبار:

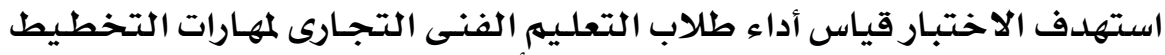

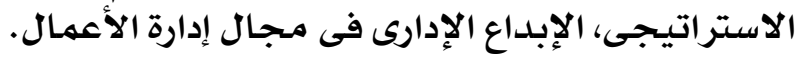

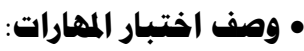

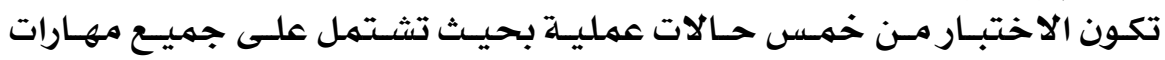

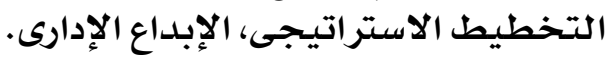

• مدرق الاختبار:

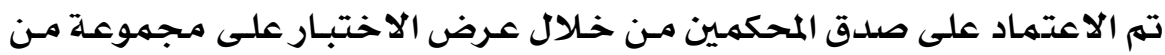

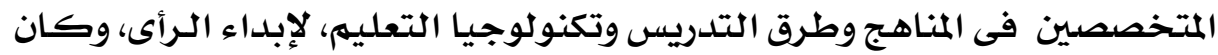

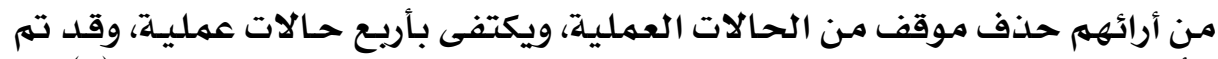

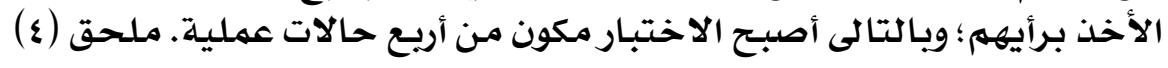
r-إعداد بطاقة هرشد التقدير الوصفى:

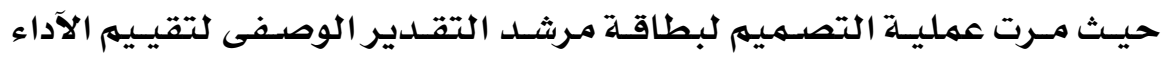
المهارى بالخطوات التتادية:

\section{$\theta$}




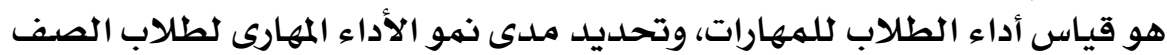

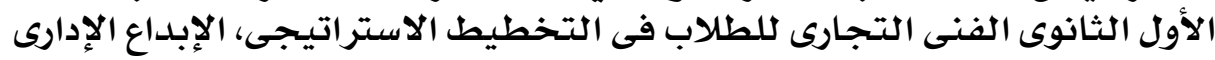

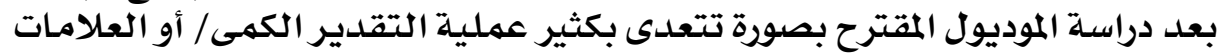

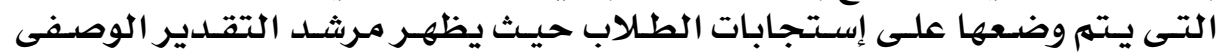

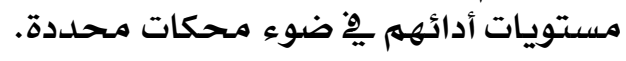

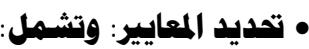

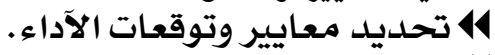

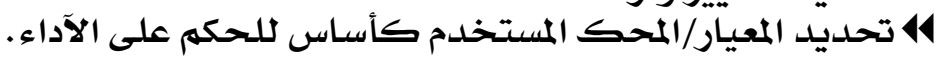

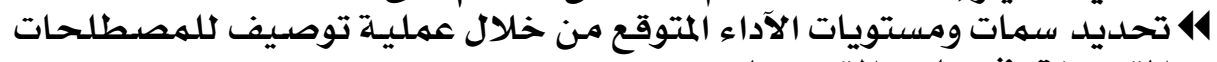

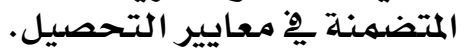

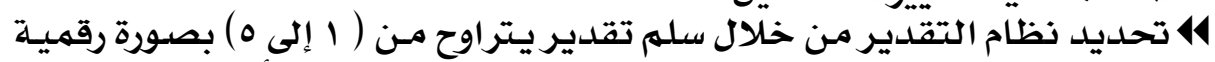

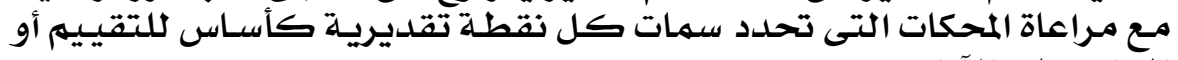
الحكمه على الآداء.

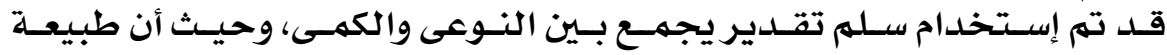

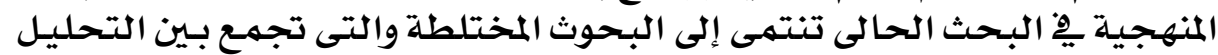

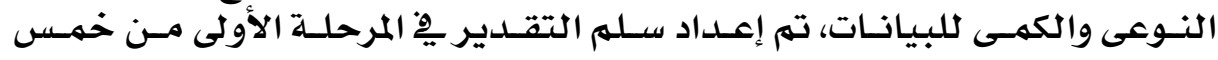

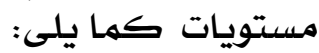

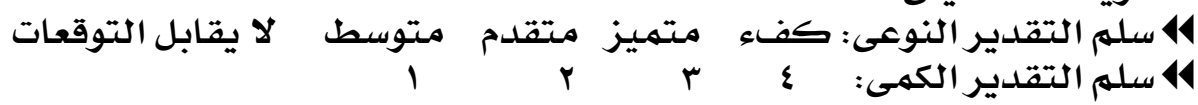
• مصادر إعداد البطاقة:

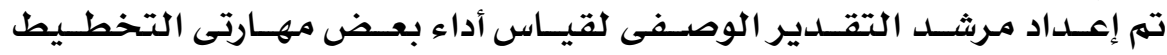

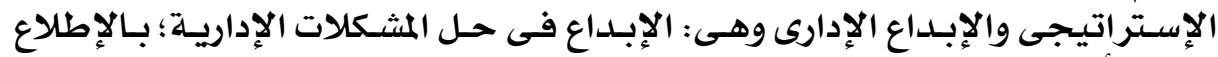

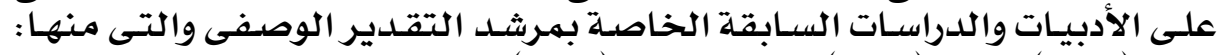

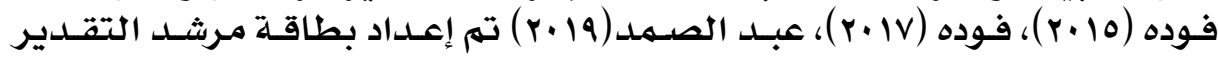

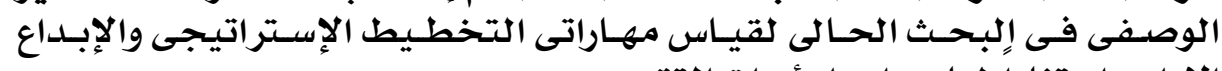

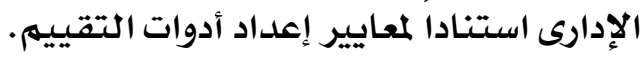

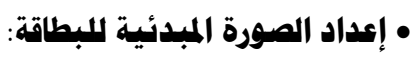

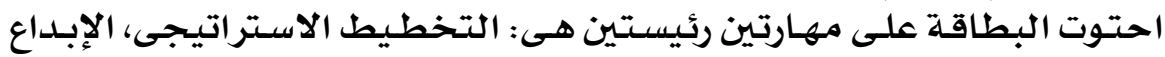

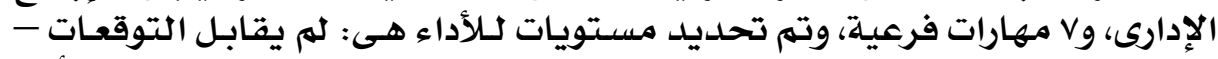

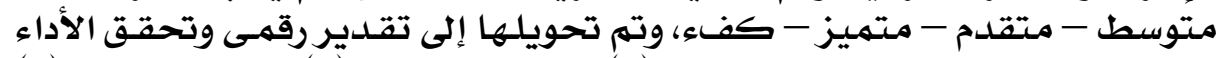

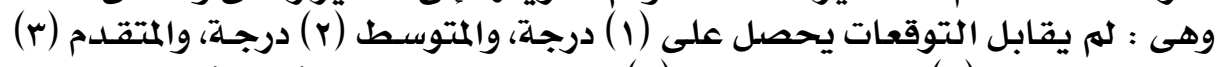

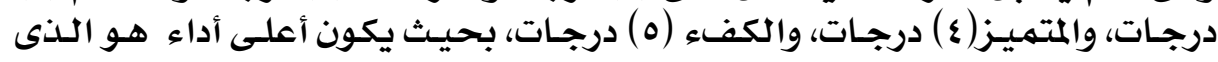

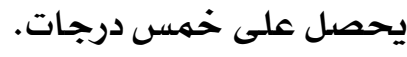

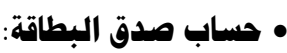

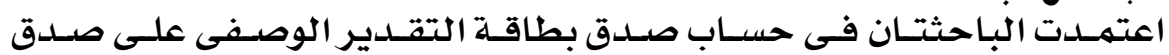

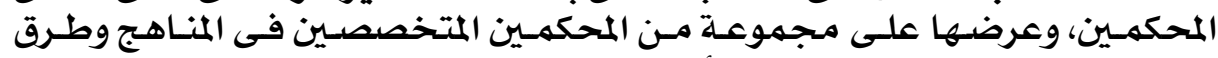
تدريس العلوم التجارية وذلكيا ملك للتأكسد مها ميلى: 


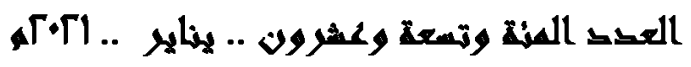

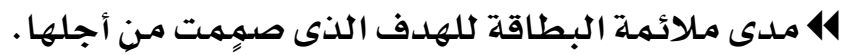

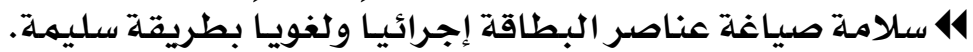

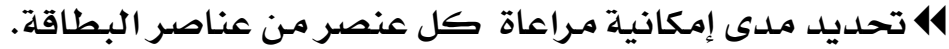

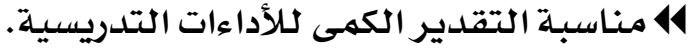
وقد أبدى المحكمون بعض الملاحظات من أهمها مـا يلى:

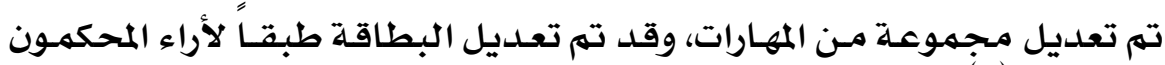
وتحتوى على (v) مهارة فرعيله.

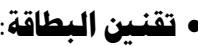

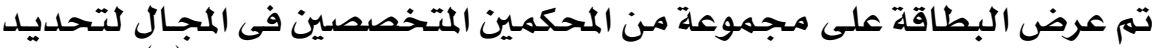

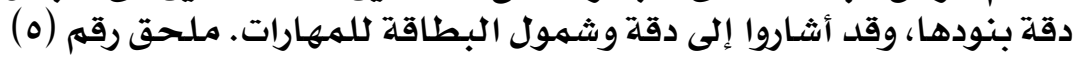
• • إجراءات التطبيق، وتحليل البيانات:

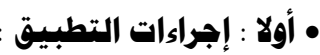

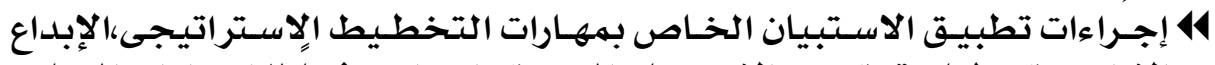

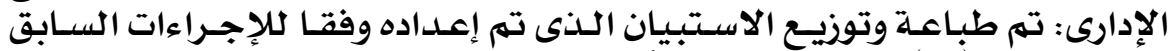

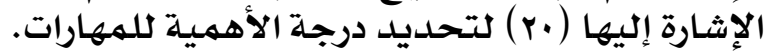

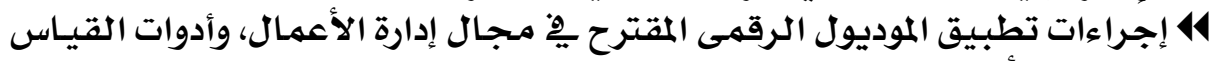

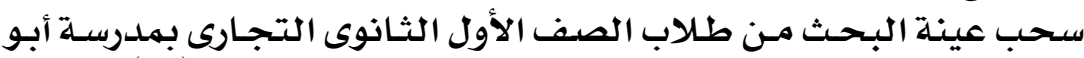
تضمنت الأتى: أطبيق

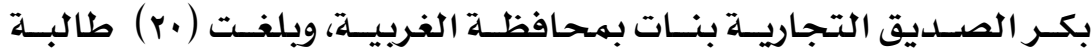
كمـجموعة تجريبية الصبية. تطبيـق الاختبـارات: اختبـار المعـارف وكـذلك الاختبــار الادائسى لمهـارات

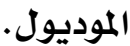

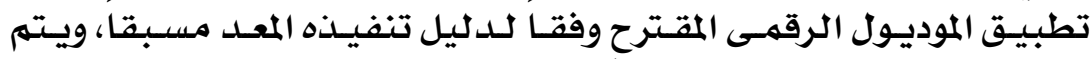

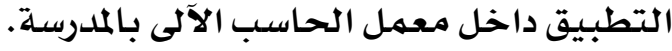

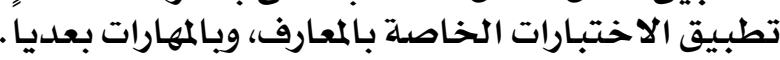

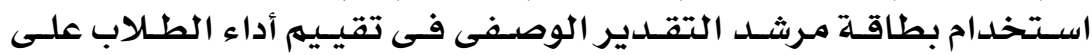

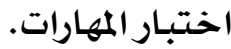

• بانيا : إجراءات تهليل البيانات الخاصة بالأدوات:

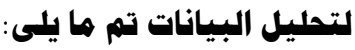

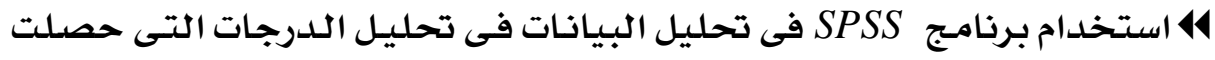

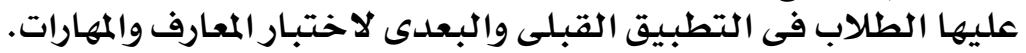

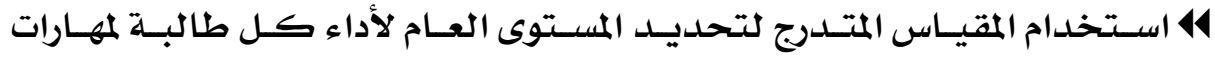

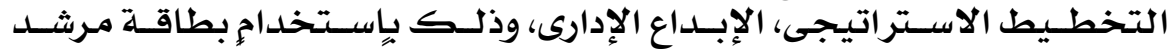

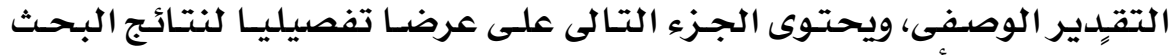
وفقا لترتيب الأسئلة.

\section{$\bullet \bullet$}


فيهـا يلى عرض ائح تفصِيلى لنتائج البحث للإجابـة عن أسئلة البحث، واختبـار

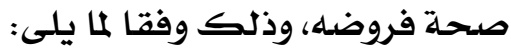

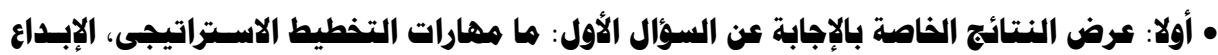

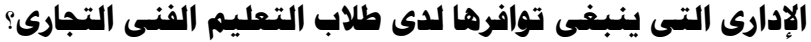

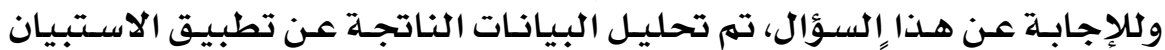

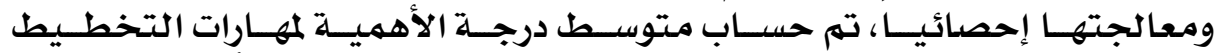

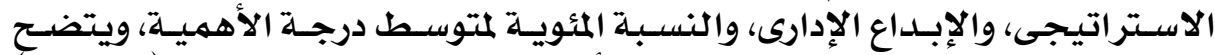

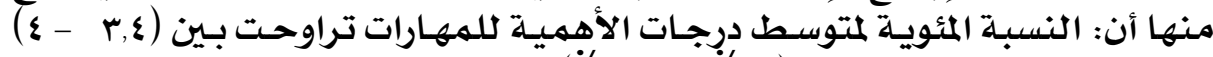

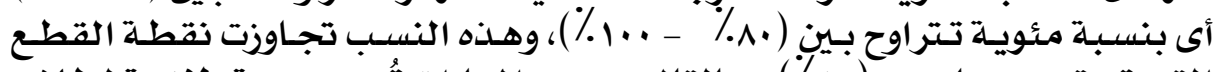

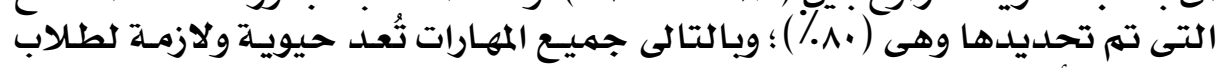

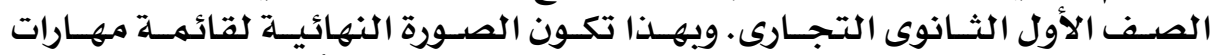

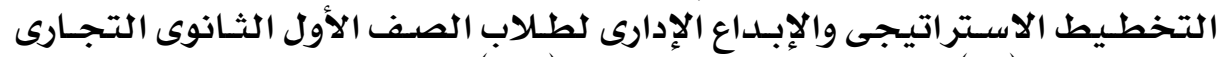

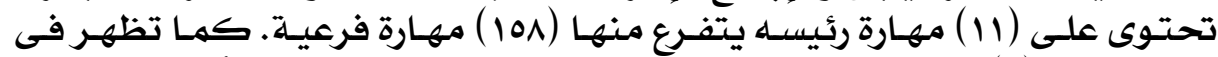

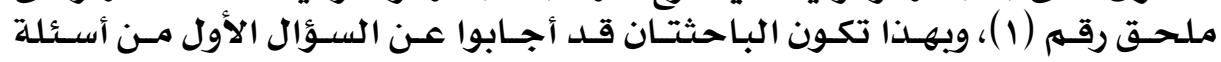

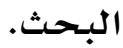

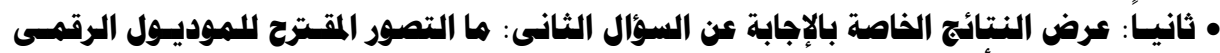

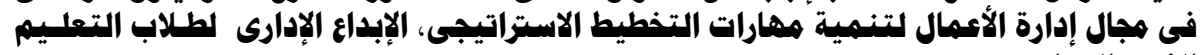

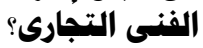

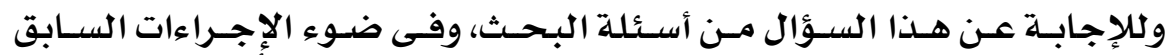

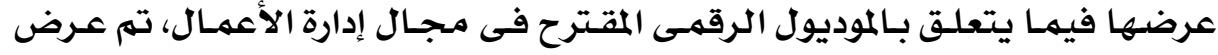

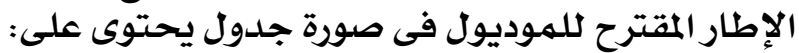
14

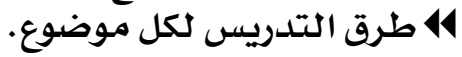

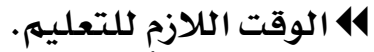
414 الوسائل والأنشطة التعليمية. 14 14 أساليب التقويم المقترحة. 14

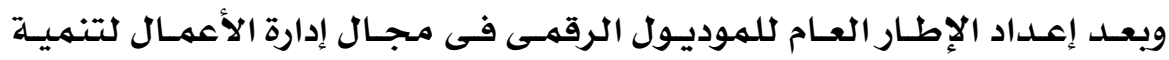

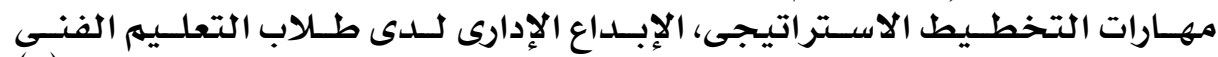

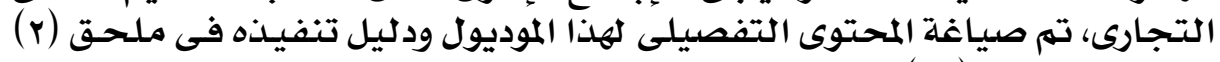

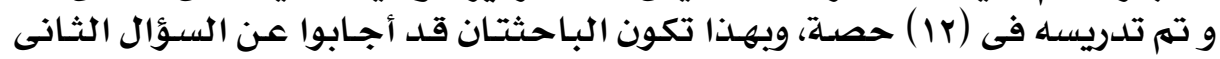

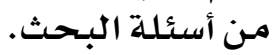

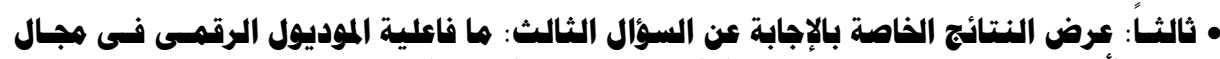

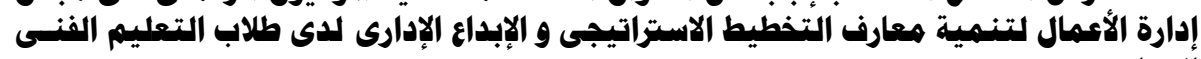

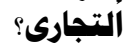

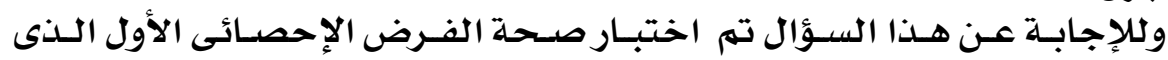

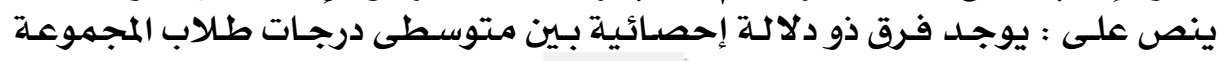

\section{7}




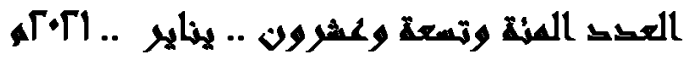

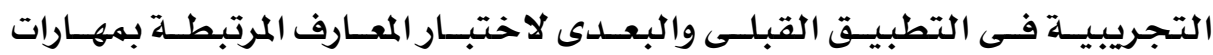

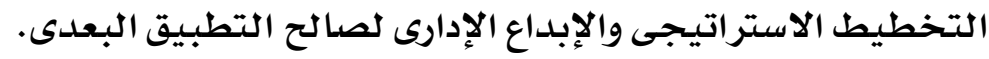

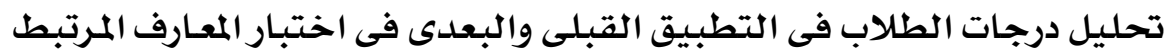

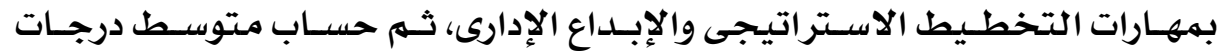

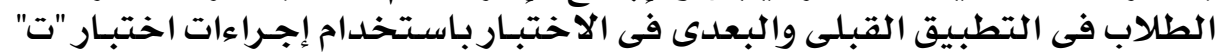

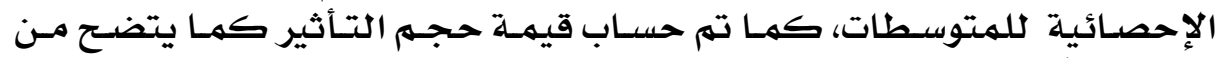

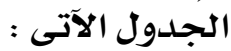

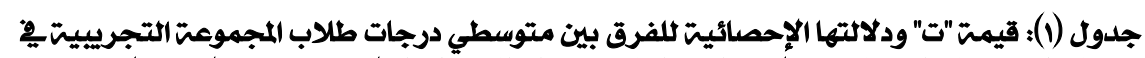

\begin{tabular}{|c|c|c|c|c|c|c|c|}
\hline 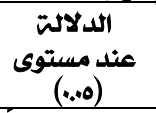 & "تيم" & مستوى & الحريتً & الالحمراف & الحسابي & ن & المجموعت \\
\hline دالت إحصائيا & PQ.81 & $(\cdots \cdots 1$ & 19 & $\begin{array}{l}7.24 \\
r .94\end{array}$ & $\begin{array}{l}79.00 \\
11.10\end{array}$ & r. & التجريبيتي بعديا \\
\hline
\end{tabular}

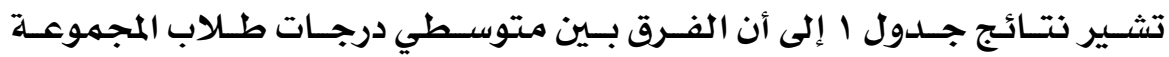

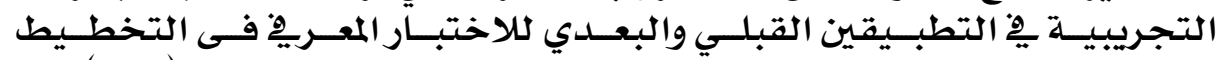

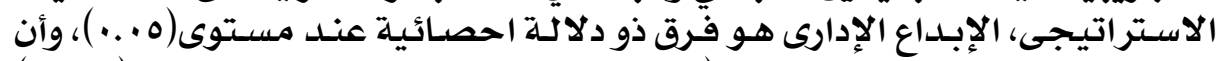

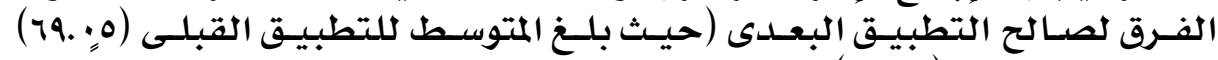

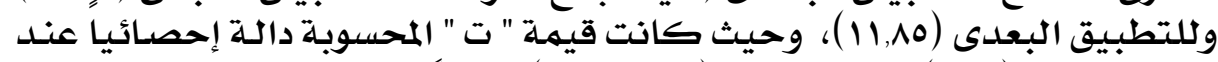

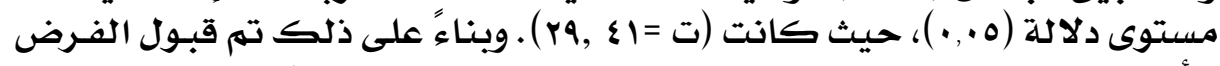

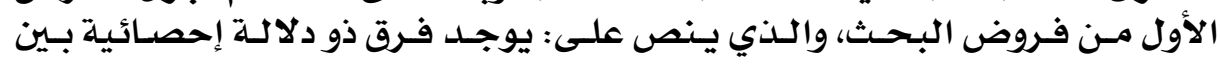

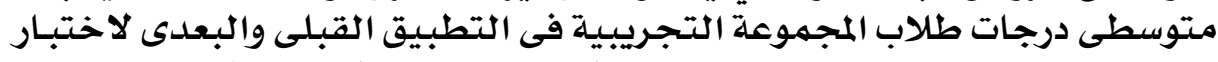

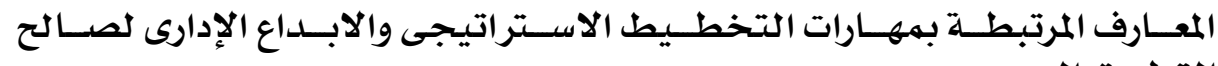
التطبيق البعدى.

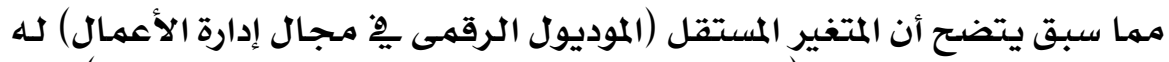

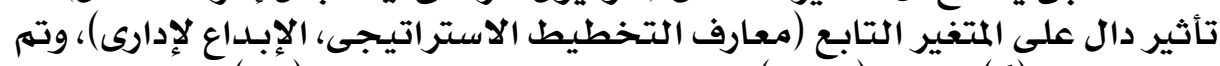

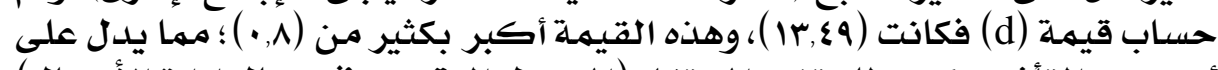

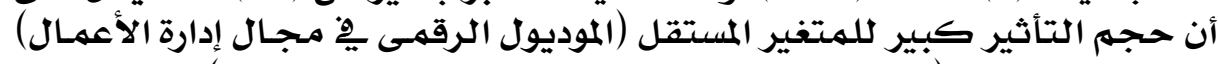

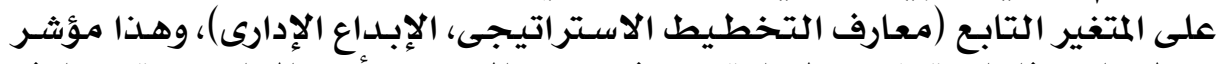

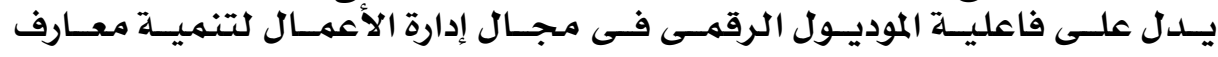

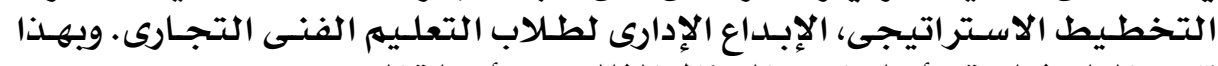

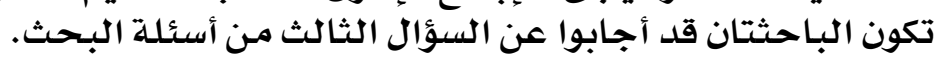

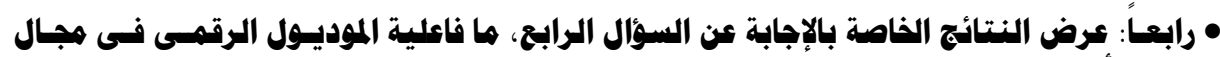

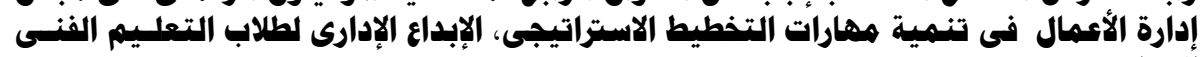

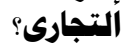

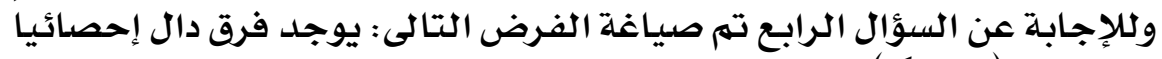

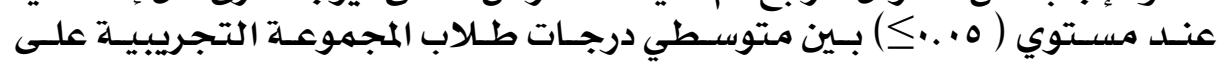

\section{$\bullet V$}




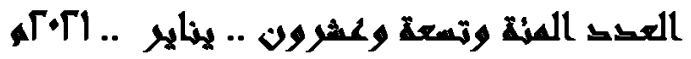

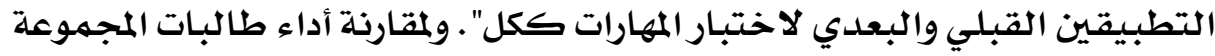

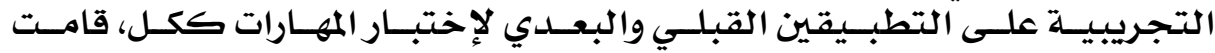

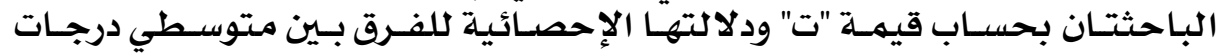

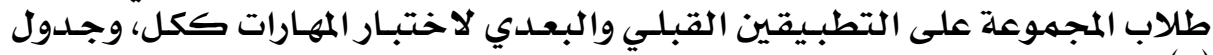

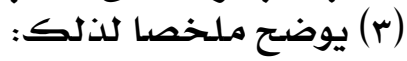

جدول ץ: قيمة "ت" ودلالتها الإحصائية للفرق بين متوسطي درجات طلاب المجموعت التجريبيت على لإئي التطبيقين القبلي والبعلي لاختبار المهارات ككل.

\begin{tabular}{|c|c|c|c|c|c|c|c|}
\hline عند مستوى الدالت & "تيمت & مستوى الدلثة & درجتي & الانعياري & الحسابي المتوسط & $\dot{ن}$ & المجحموعت \\
\hline دالت إحصائيا & $01 . \wedge 1$ & 1.+י1) & 19 & O.M & 71.70 & $r$ & التجريبييت بعدييا \\
\hline
\end{tabular}

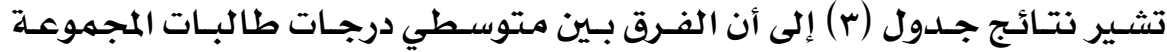

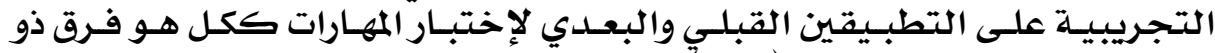

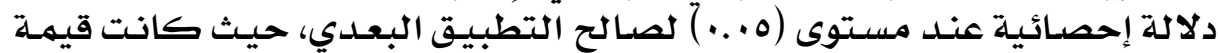

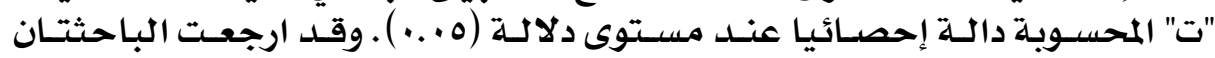

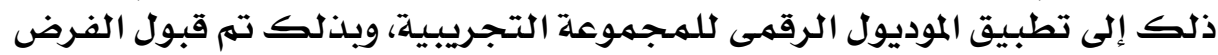

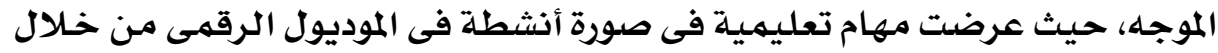

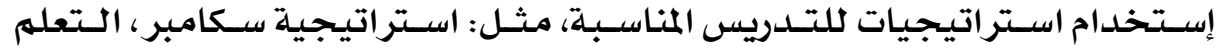

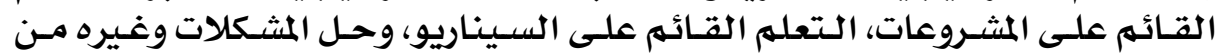

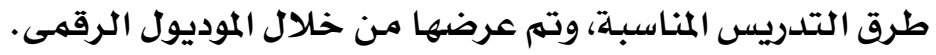

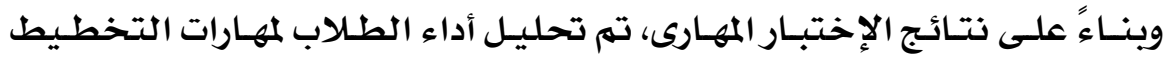

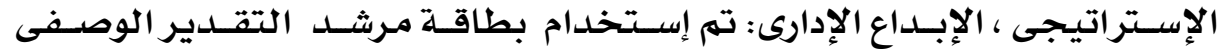

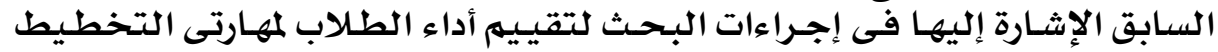

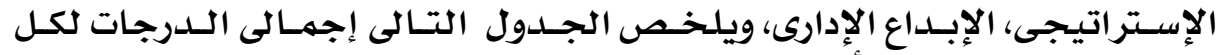

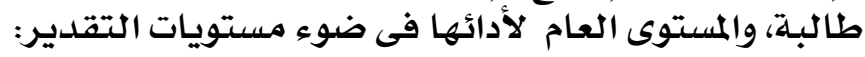

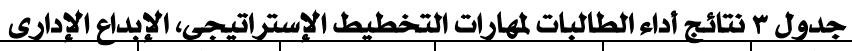

\begin{tabular}{|c|c|c|c|c|c|c|c|}
\hline المستوى & النسبيتي & إجمالى & الطالبت & المستوى & النمبتيتي & إجمالى & الطالبت \\
\hline متميز & 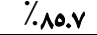 & $r$. & 11 & متقدم & 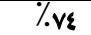 & YT & 1 \\
\hline كفء & $\%$ & $r r$ & Ir & كفي & $\% .9 \varepsilon$ & $r r$ & $r$ \\
\hline متقلدم & \%vv.1 & $P V$ & ir & كفه & $\%$ & $r r$ & $r$ \\
\hline كفو & $\% .9 v .1$ & $r \varepsilon$ & $1 \varepsilon$ & متميز & $\% . \wedge \Lambda .0$ & $m$ & $\varepsilon$ \\
\hline متقدم & $\%$ \% $1 . \varepsilon$ & ro & 10 & متميز & $\%$ \%^.० & $m$ & 0 \\
\hline كفء & $\%$ \% v. & $r \varepsilon$ & 17 & متميز & $\%$ \%1. & $r r$ & 7 \\
\hline متميز & $\%$ & $r r$ & IV & كفء & $\%$ & $r r$ & $V$ \\
\hline كفء & $\%$ \% v. & $r \varepsilon$ & M & متميز & $\%$ \%1. & $r r$ & $\Lambda$ \\
\hline متميز & $\%$.. & $\mathrm{YA}$ & 19 & كفه & $\%$ & $r r$ & 9 \\
\hline متقدم & $\%$.ی. & YA & $r$. & كفه & $\%$ \% & $r r$ & 1. \\
\hline
\end{tabular}

\section{$\bullet \wedge$}




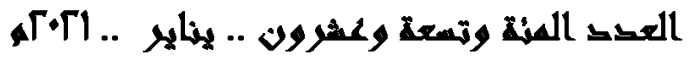

$$
\text { يتضح من الجدول (r) ما يلى : }
$$

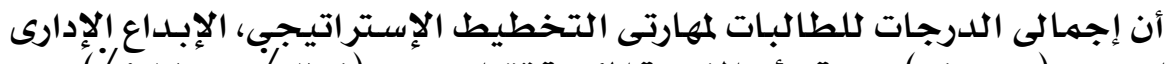

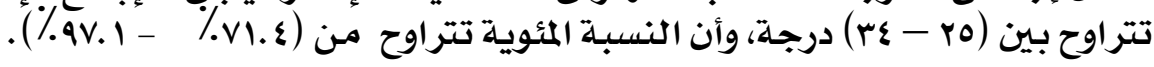

$$
\text { فى ضوء المستويات المقترحة يتضح أن : }
$$

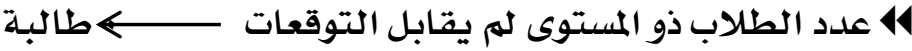

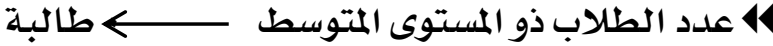

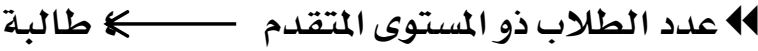

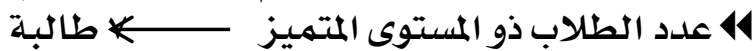

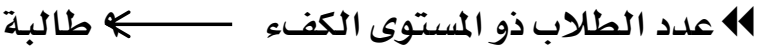

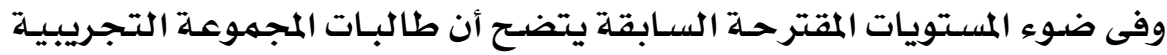

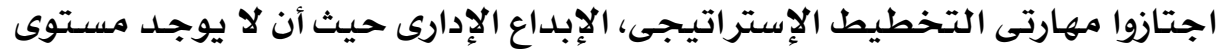

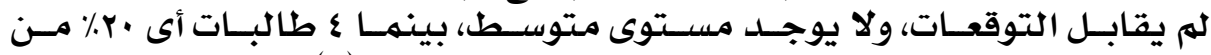

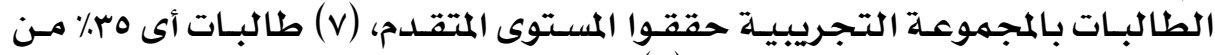

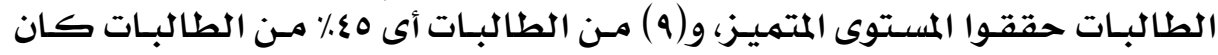

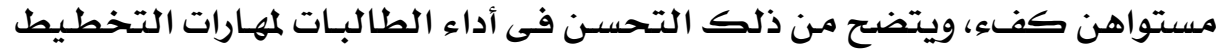

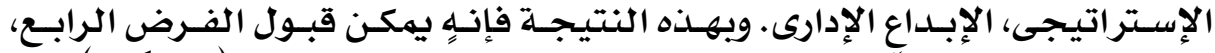

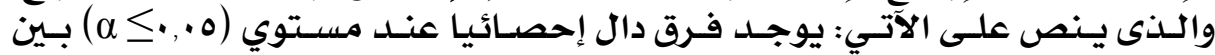

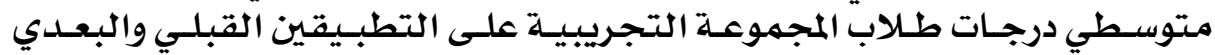

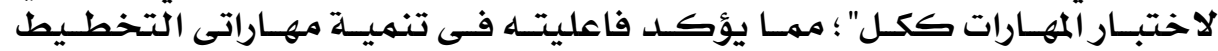

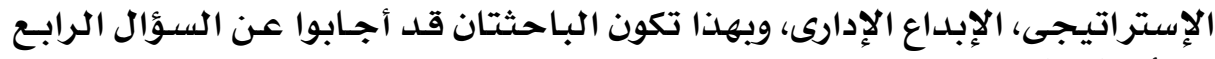
من أسئلة البحثى الإبلاعت

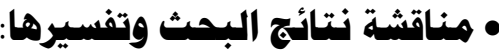

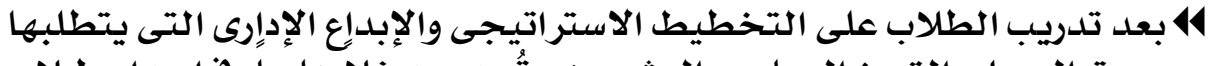

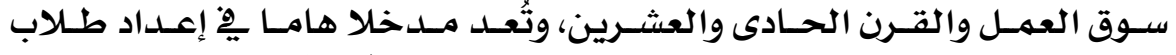

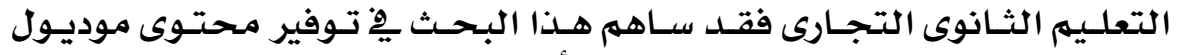

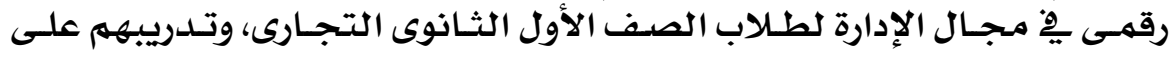

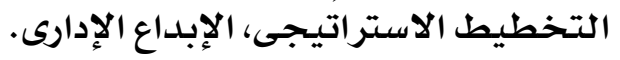

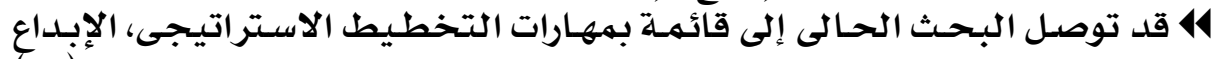

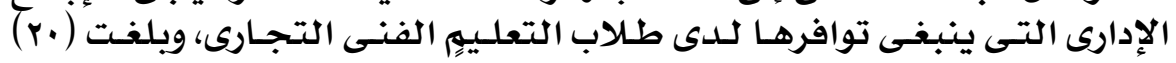

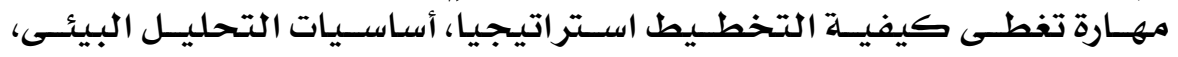

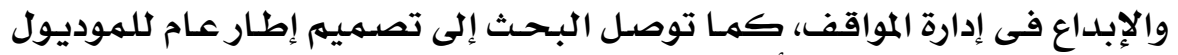

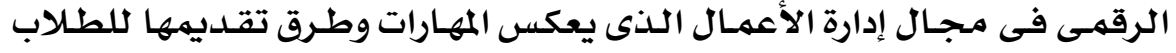

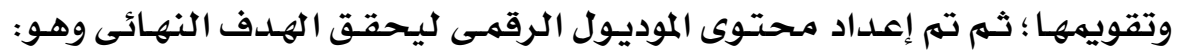

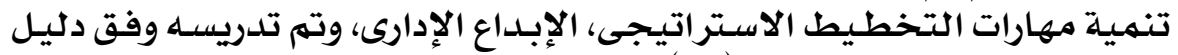

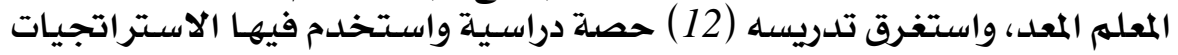

\section{$\bullet 9$}




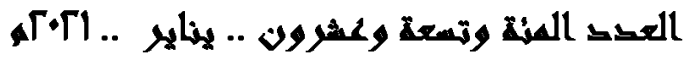

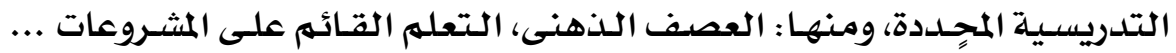

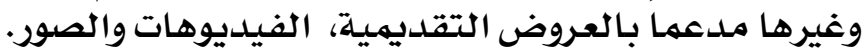

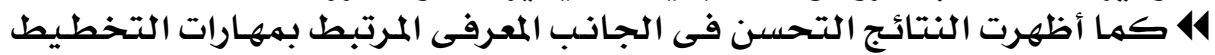

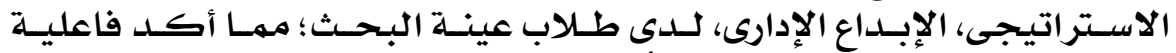

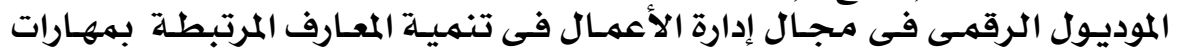
التخطيط الاستراتيجى فئى الإبداع الدارة الإدارى.

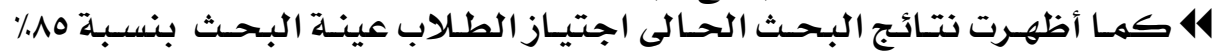

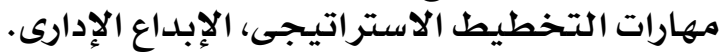
11

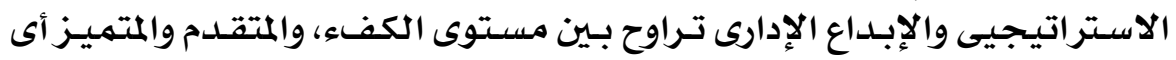

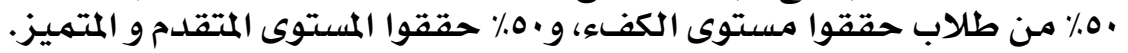

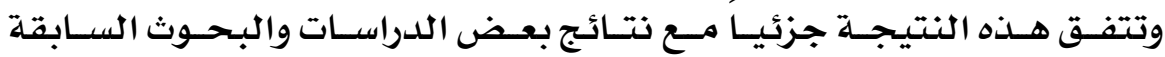

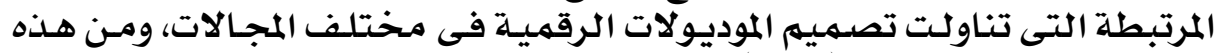

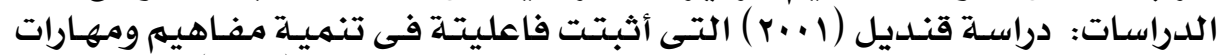

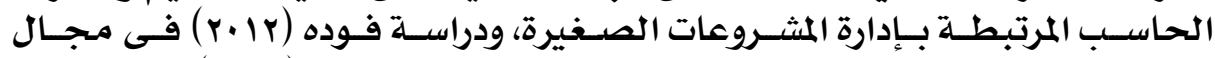

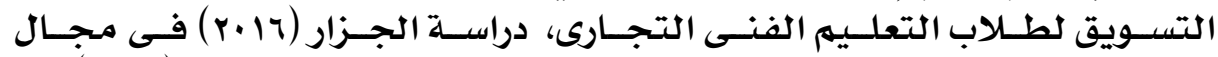

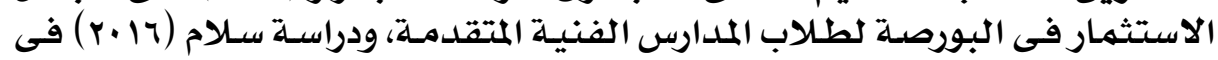

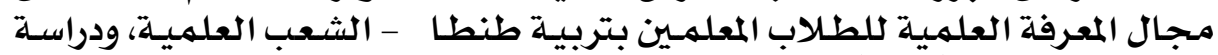

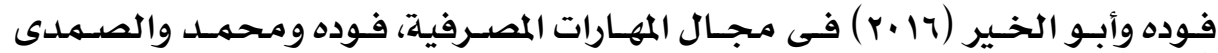

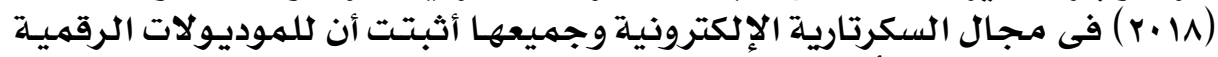

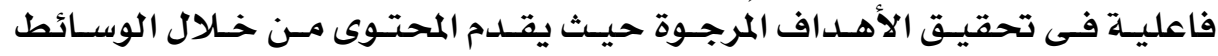

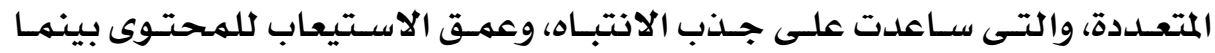

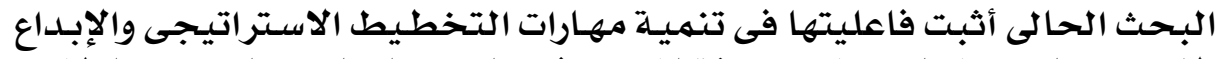

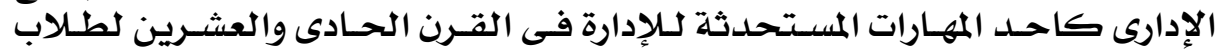

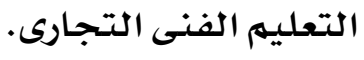

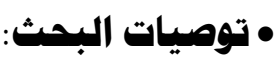

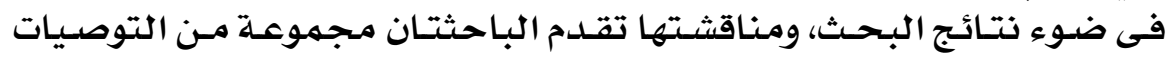
كما يلى:

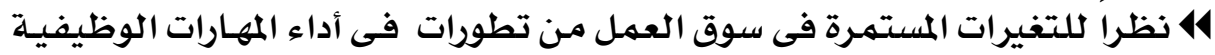

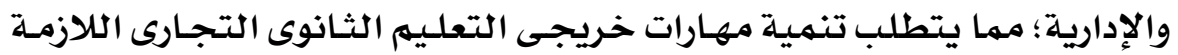

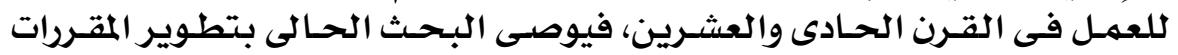

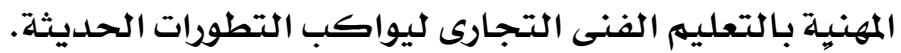

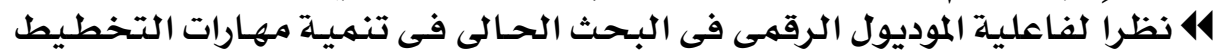

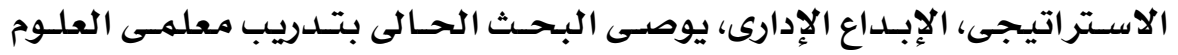

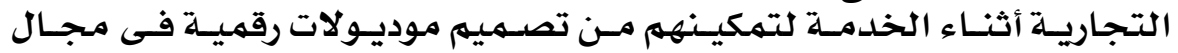
تخصصهم.

\section{7.}




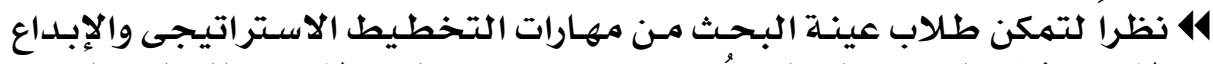

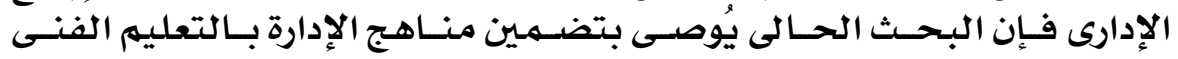
التجارى، والعام لهذه الإنهام المهارات.

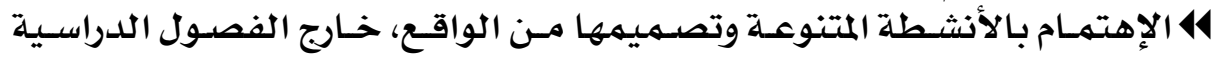

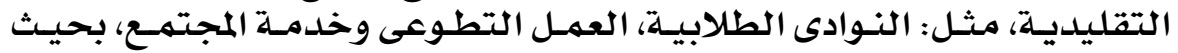

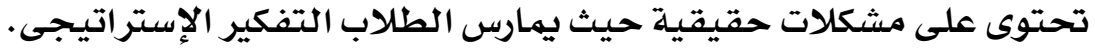

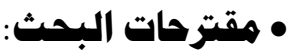

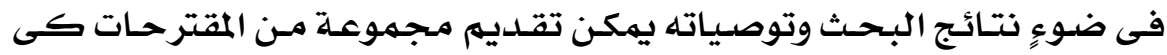
تكون امتدادا للبحث فئر البحالى ومنها:

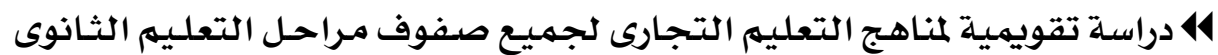

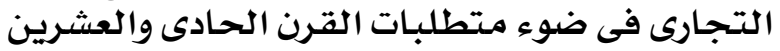

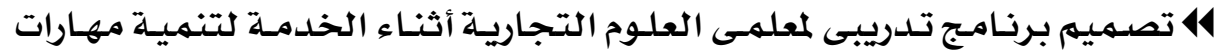

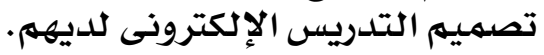

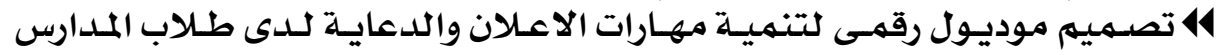

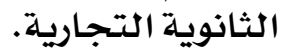

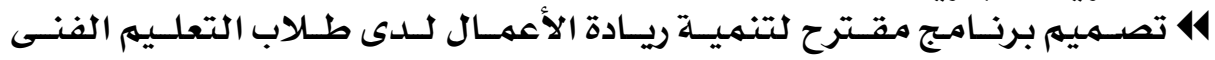
التجارىى.

• المراجع:

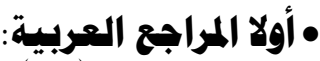
- أبو العزم، إيهاب (rا.r). الرخصتة الدواجية الدوليت لقيادة الحاسب الآلى، طا. (ليبيا: دار الحكمت للطباعت

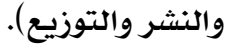

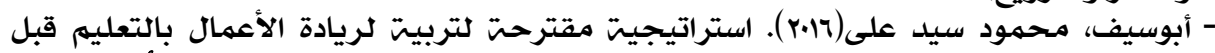

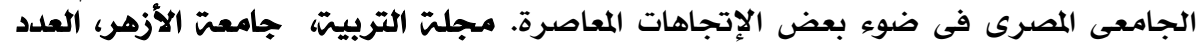

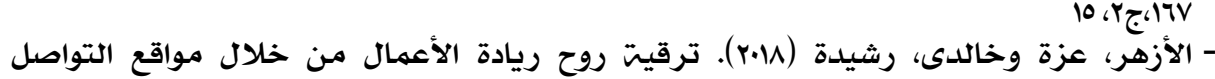

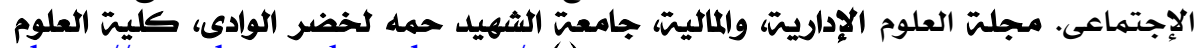

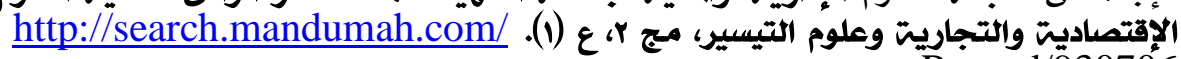

Record/930706

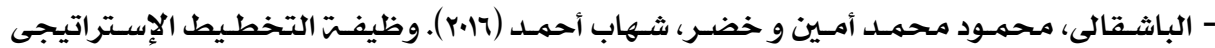

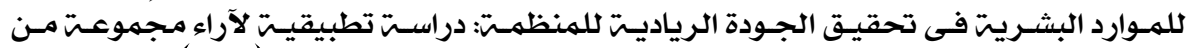

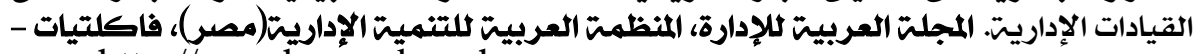

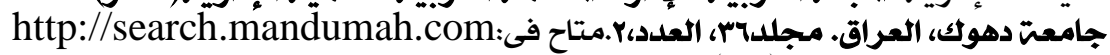

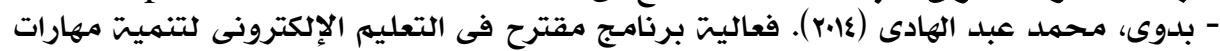

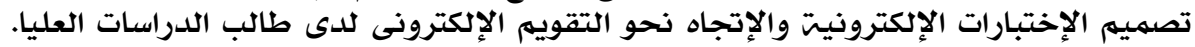

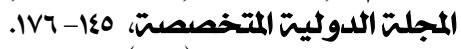

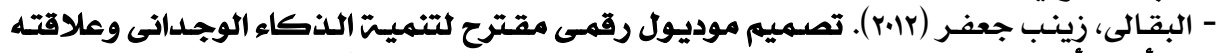

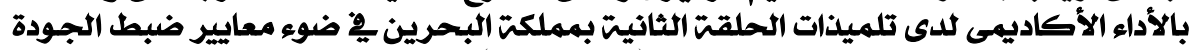

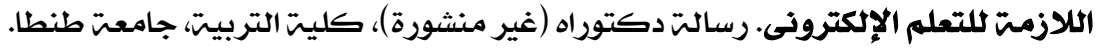




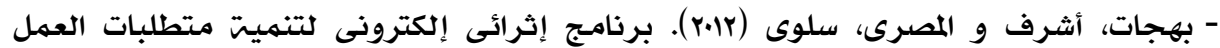

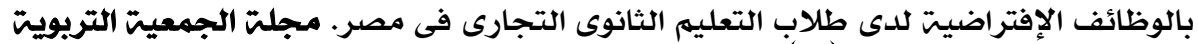

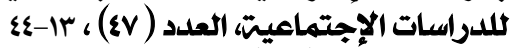

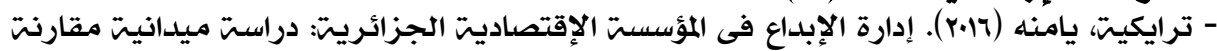

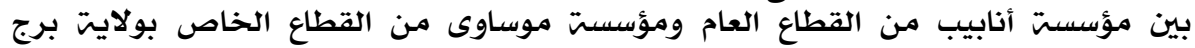

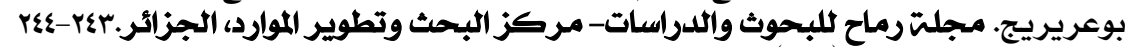

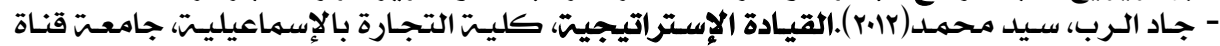
- جرجر، ابراهيه البشير عبد الحميد (10.rم). متطلبات تطبيق التخطيط الإستراتيجى. المجلتة

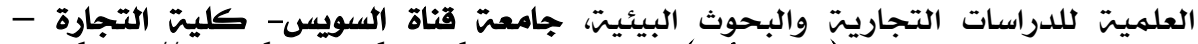

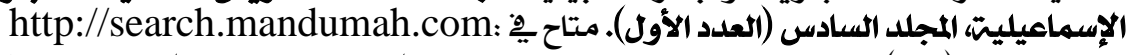

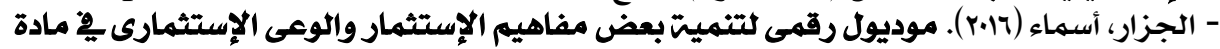

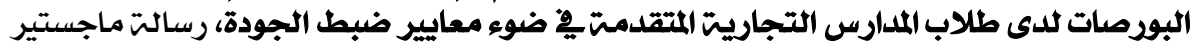

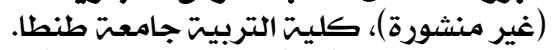

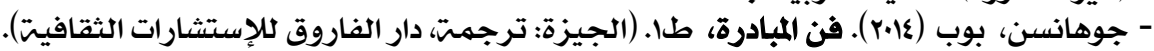

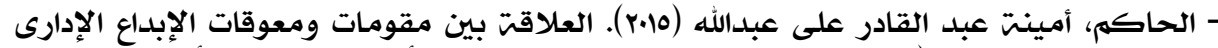

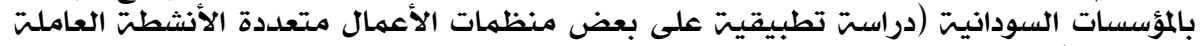

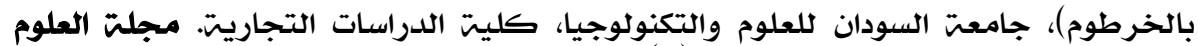

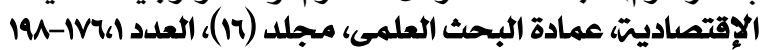

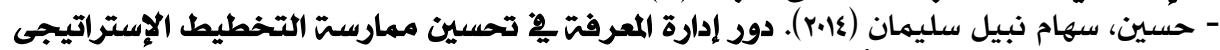

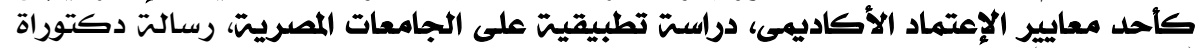

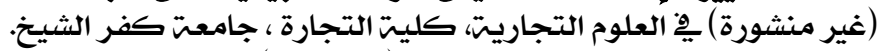

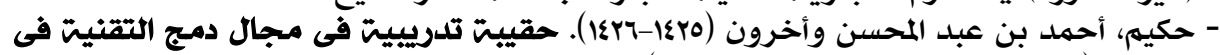

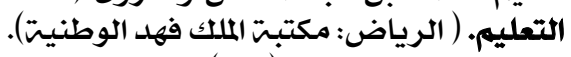

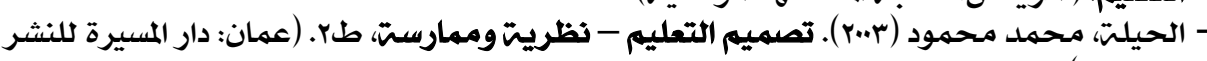
والتوزيع).

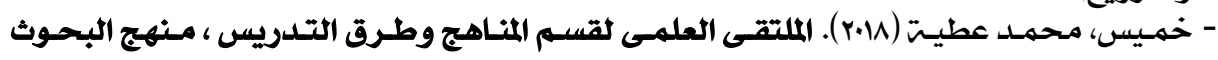

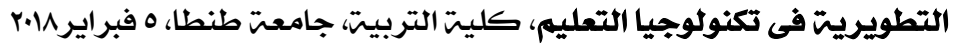

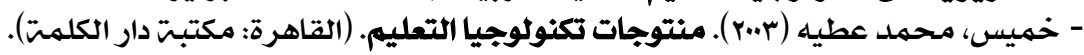

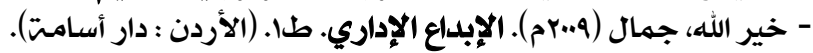

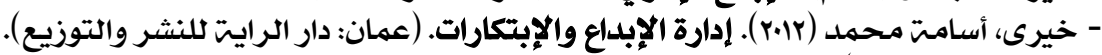

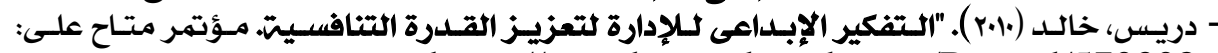
https://search.mandumah.com/Record/570308

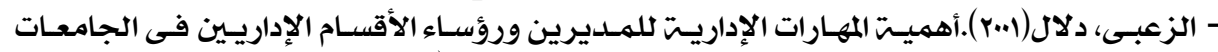

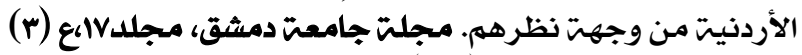

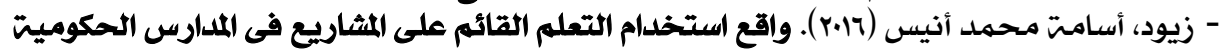

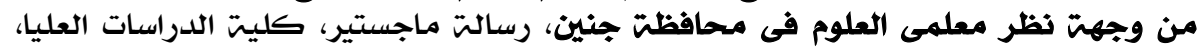

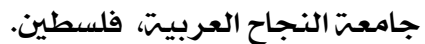

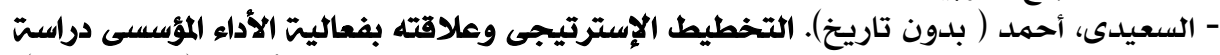

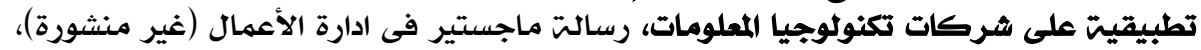
سلطنت عمان، Internationnal Virtual University (U.K) متاح على : abahe.co.uk 


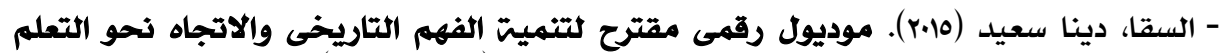

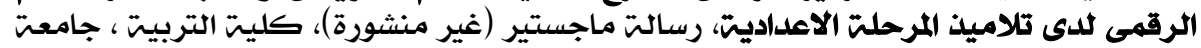

طنطا.

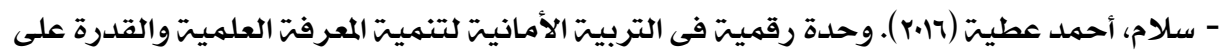

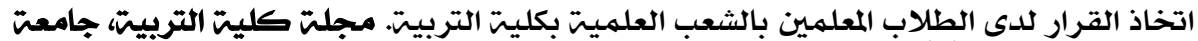

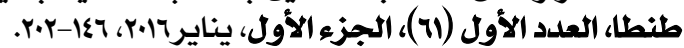

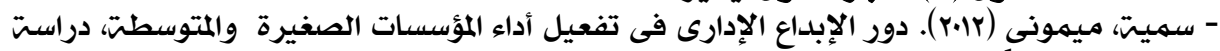

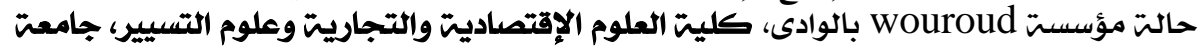

قاصلدى مرباح. - الشربينى، فوزى واهیى والطناوى، عفت(11). تطوير المناهج التعليميت. (عمان: دار المسيرة للنشر والتوزيع). - (1) -

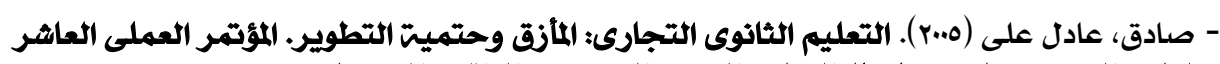

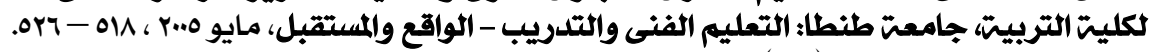

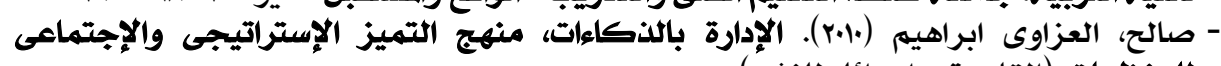

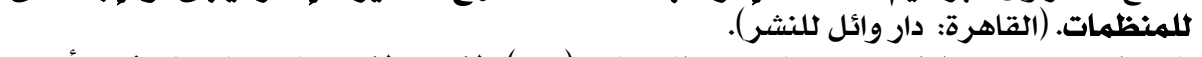

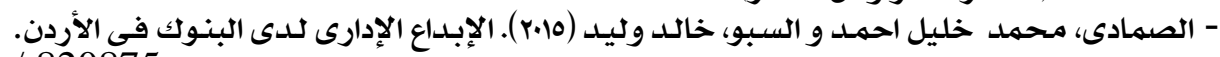

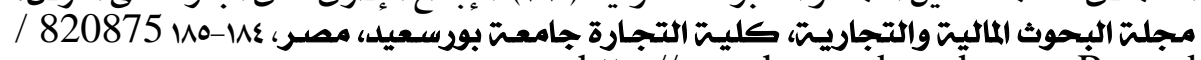
http://search.mandumah.com/Record

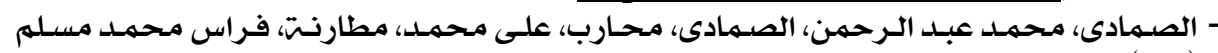

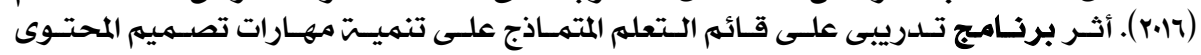

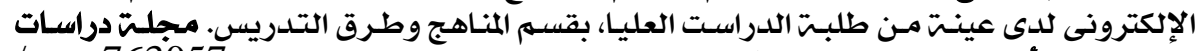

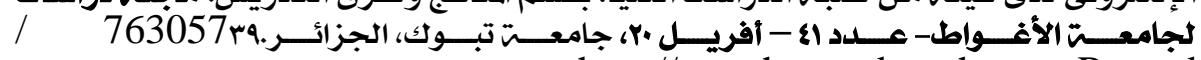
http://search.mandumah.com/Record

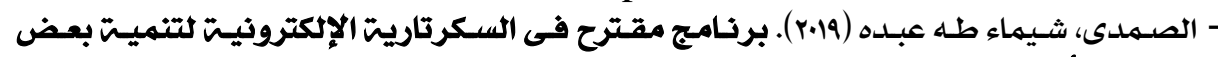

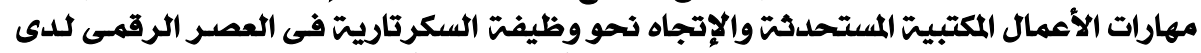

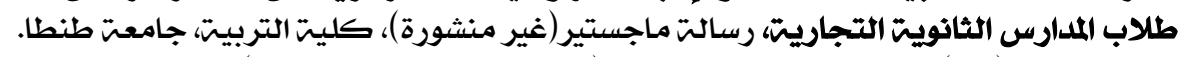

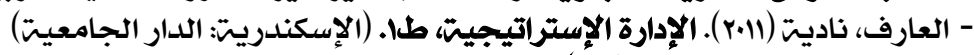

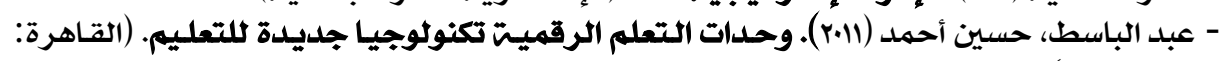

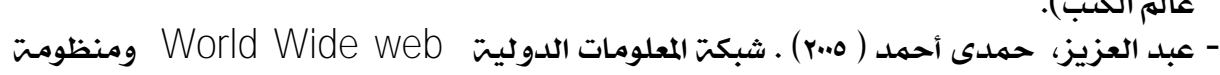

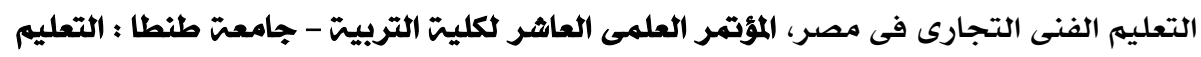

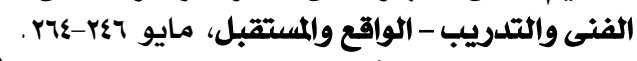

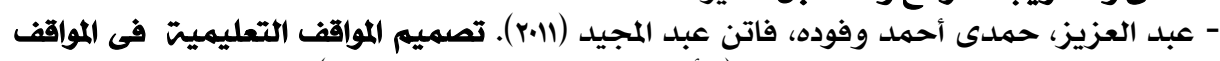

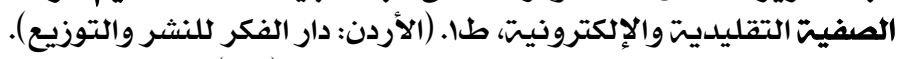

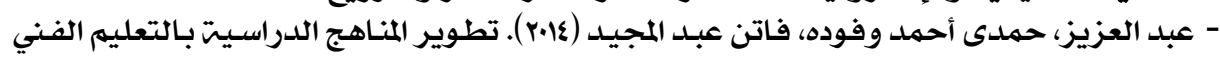

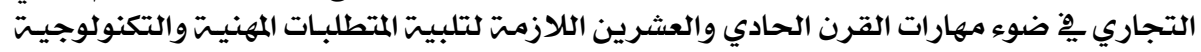

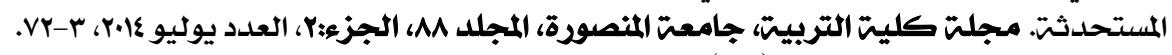

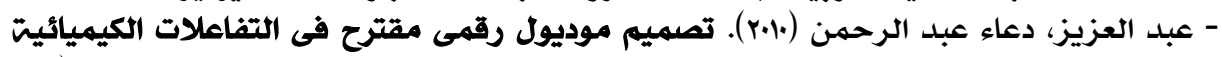

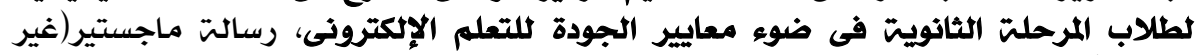

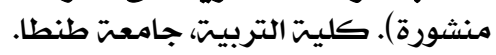




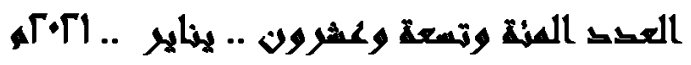

- عبد المحسن، توفيق محمد (V. ا.r). مبادىء الإدارة والتنظيم أسرار نجاح الإدارة اليابانيت. (القاهرة:

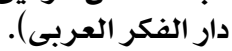

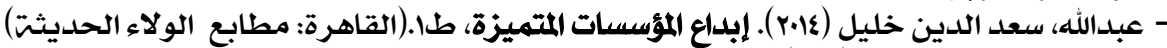

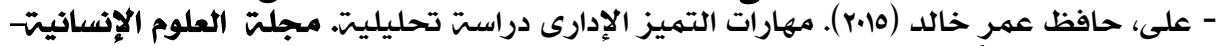

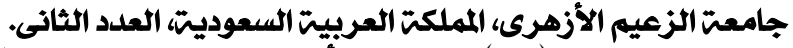

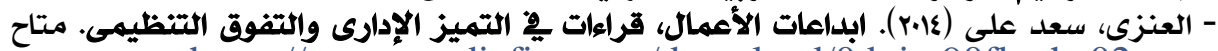

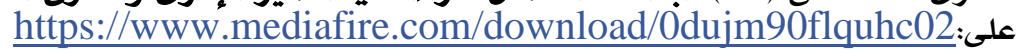

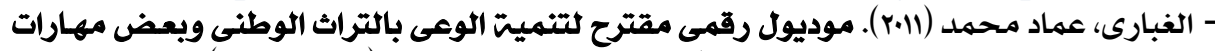

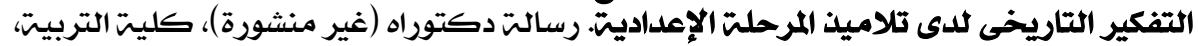
جامعتن طنطا.

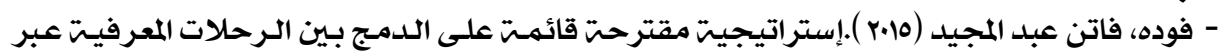

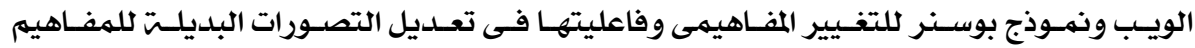

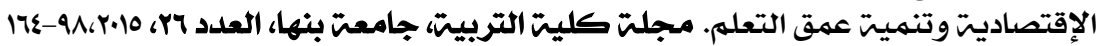

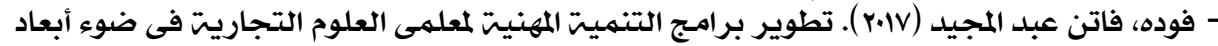

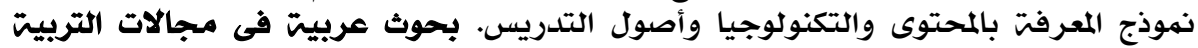

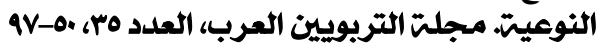

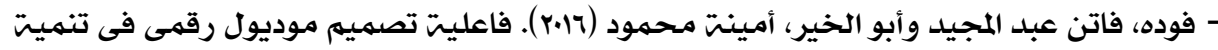

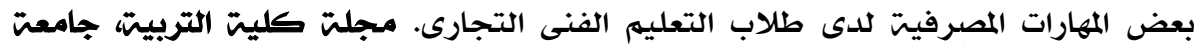

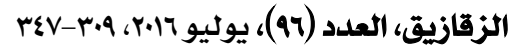

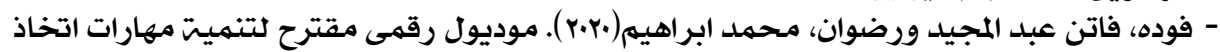

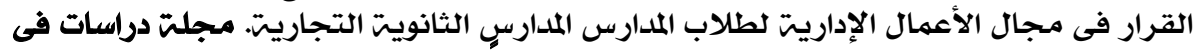

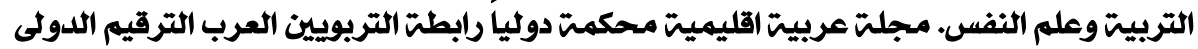

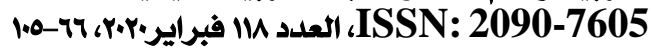

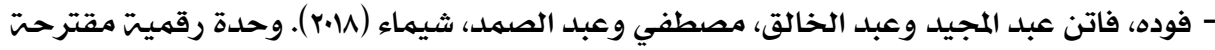

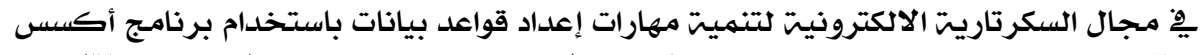

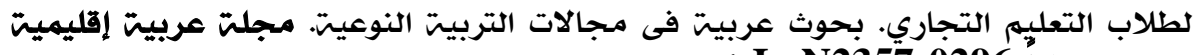

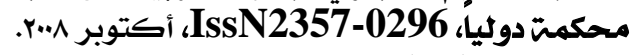
- الفيل، حلمى(19.ب). متغيرات تربويت حديثت على البيئت العربيتة، (تأصيل وتوطين). (القاهرة: دار

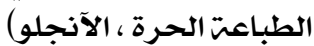

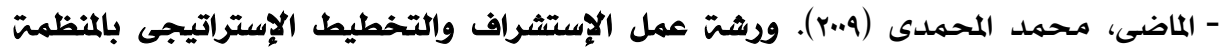

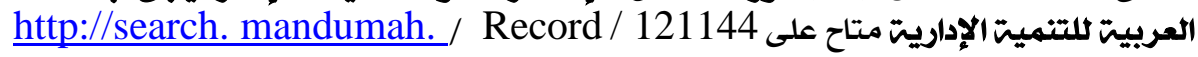

com

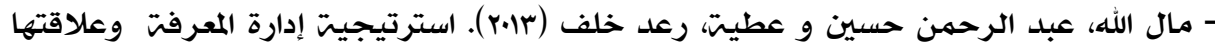

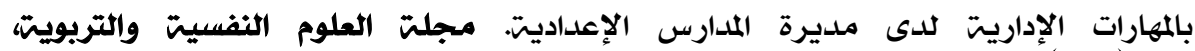

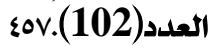

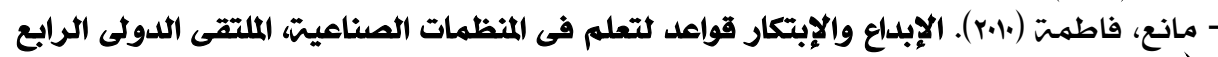

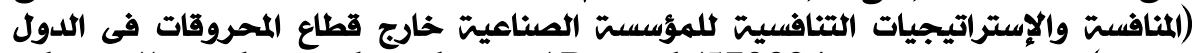

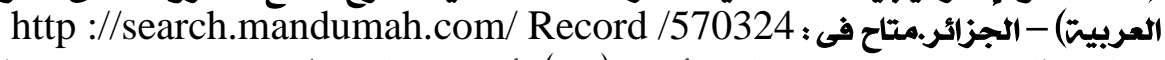

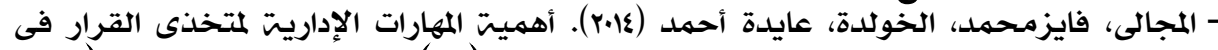

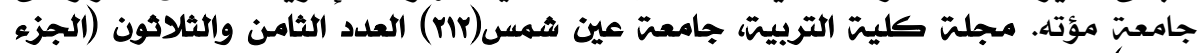
الثالث). 


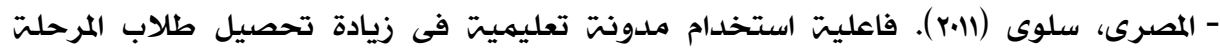

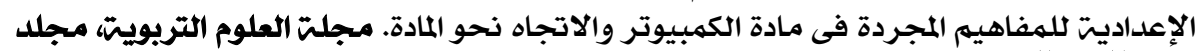

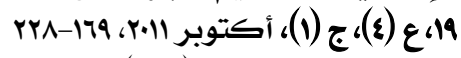

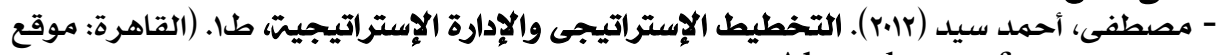
المؤلف:Ahmadmostafa.com

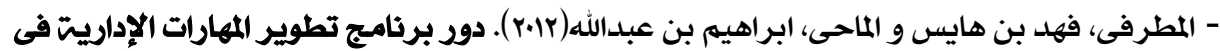

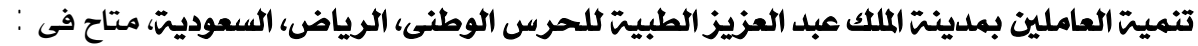
http://search.mandumah.com/Record / 535180

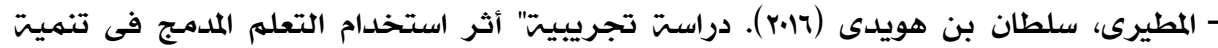

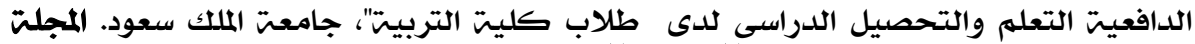

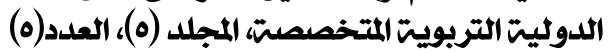

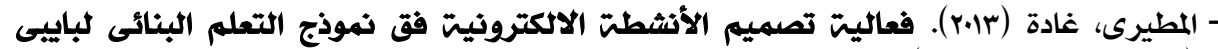

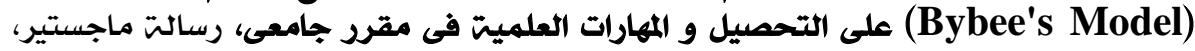

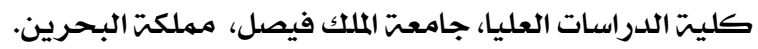

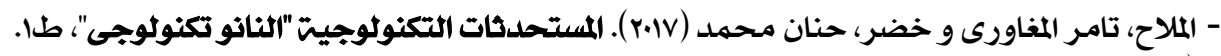

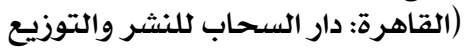

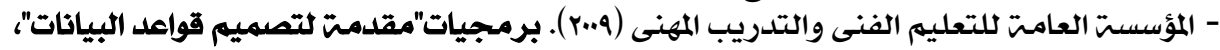

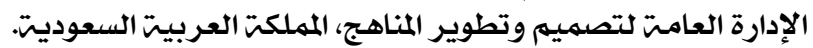

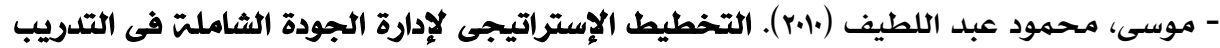

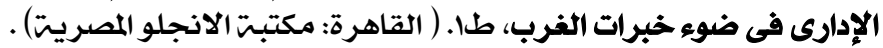

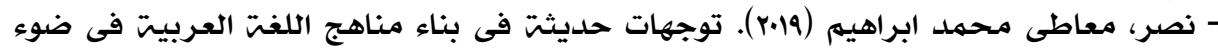

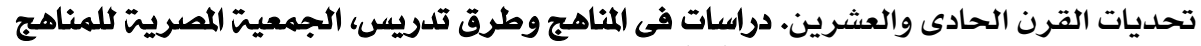

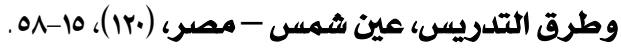

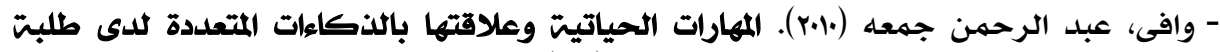

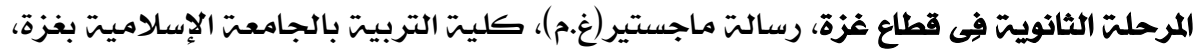
فلسطين.

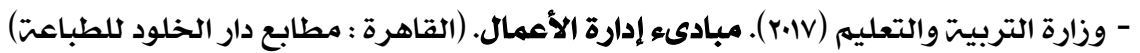

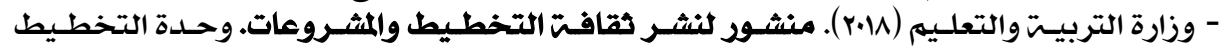

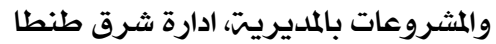

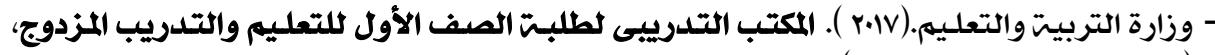

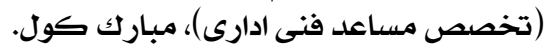

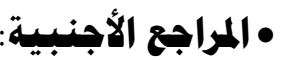

- Hiong, L. \& Osman, K. (2013). A Conceptual Framework for the Integration of 21st Century Skills in Biology Education, Research Journal of Applied Scinces, Engineering and Technology, Vol. 6, No. 16, pp. 2976-2983.

- Herrmann-Nehdi. A., (2014). Creativity and Strategic Thinking: The Coming Competencies. Available At: www.hbdi.com. 1-6.

- Kloppenborg, T. (2009). Contemporary project manament: Organize / 
- Margaret, A. \& Pac, O. (2009). Modern office technology and the secretary's productivity in private business organizations. African Journal of Business Management, V. 3 (8), 333-339.

- Matthew, M.(2010).Access 2010: The Missing Manual, O’Rilly Media, Inc., United States of America. Plan/ perform. Mason, $\mathrm{OH}$ : Southwestem Cengage learning.

- Simonson, M. (2005).Teaching and learning at a distance: Foundations of distance education, upper Saddle River: NJ: Prentice -Hall

- Hiong, L. \& Osman, K. (2013). A Conceptual Framework for the Integration of $21 \mathrm{st}$ Century Skills in Biology Education. Research Journal of Applied Scinces, Engineering and Technology, V. 6, N. 16, 2976-2983. 